

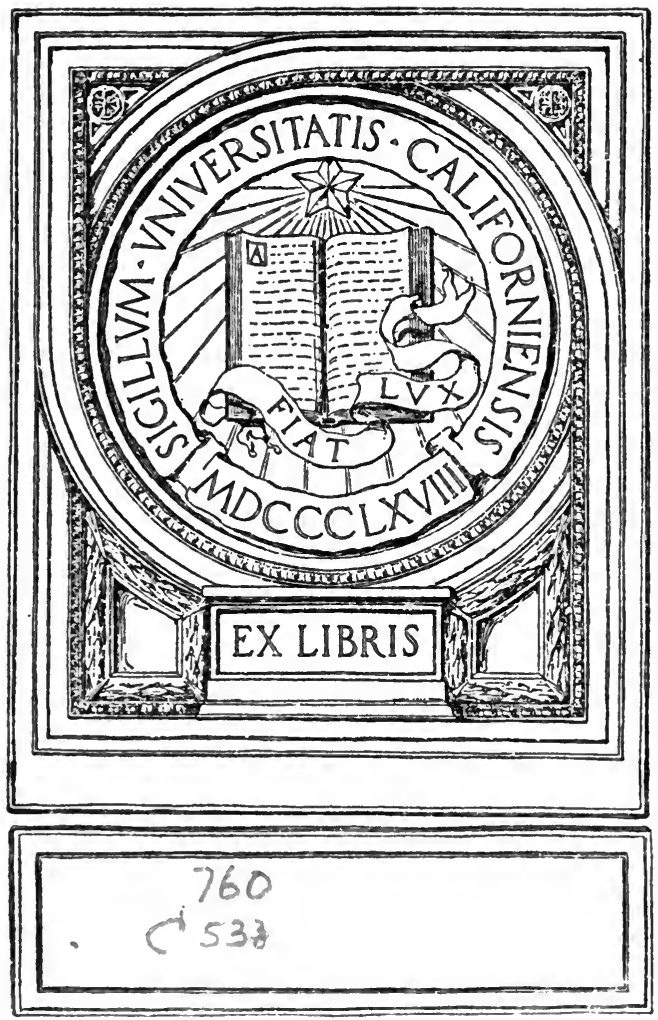
Y $\quad=$

.

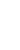

45

$+$

a 



\section{BEGINNERS' LATIN BY THE . DIRECT METHOD}




\section{Digitized by the Internet Archive in 2007 with funding from Microsoft Corporation}




\section{BEGINNERS' LA'TIN}

BY THE

\section{DIRECT METHOD}

BY

\section{EDWARD C. CHICKERING, Ph.D.}

head of the Department of Classical laNguages in Jamaica high BCHOOL, NEW YORK CITY

AND

\section{HARWOOD HOADLEY, Ph.D.}

OF THE DEPARTMENT OF CLAGSICAL LANGUAGES IN JAMAICA HIGH SCHOOL, NEW YORK CITY

CHARLES SCRIBNER'S SONS 
Copyright 1914, BY

CHARLES SCRIBNER'S.SONS

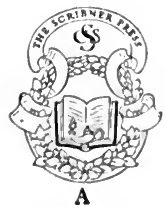




\section{PREFACE}

This book presents a series of Latin lessons for beginners, based on the principles of the Direct Method, and is the result of class-room experiments covering several years.

In it is included all the syntax recommended in Byrne and in the standard syllabi for the first year of Latin. Five hundred of the commonest words in high school Latin, as shown in Lodge, are printed in the General Vocabulary in heavy type. This vocabulary is intended primarily to suggest the meanings of words previously studied. Except for 'si,' 'aliquis,' and a few others, only such words as have already occurred in the lessons are used in the explanations. It also provides abundant means for developing the pupils' powers of expression through the memorizing of definitions. It is supplemented by pictures illustrating certain of the stories. - In the matter of hidden quantity Hale and Buck's Grammar has been generally followed.

For the benefit of teachers unfamiliar with the Direct Method, there are given on page xiii and following of the Teachers' Edition a discussion of the nature and principles of the Direct Method; general directions to teachers; and specific suggestions for the teaching of the individual lessons. 
In the individual lessons, the following features may be noted:

(1) Nouns, adjectives and pronouns are developed together by cases, not by declensions. With each set of forms are taught all the constructions for that particular case which are to be taught at all.

(2) The Verb is developed by mood-tenses, not by conjugations.

(3) Indirect Discourse is introduced almost at the very beginning, and in such a way that the pupils never know of its terrors.

(4) Forms and syntax are taught together by means of paradigm-sentences and type-sentences, to be memorized absolutely.

(5) These sentences are easily acted or have the form of acrostics; hence they are readily memorized.

(6) Type-questions are to be memorized with each paradigm. By means of these, there is constantly demanded of the pupil self-expression, first formal, later free, on all manner of topics.

(7) While the Nominative Case is of course to be used freely from the outset, its formal study, because of the irregularity of its forms, has been postponed until the other cases have been taught. 
(8) The earlier Reading-sections consist of wellknown stories. The appearance of familiar tales in unfamiliar dress not merely stimulates interest but greatly facilitates the task of comprehension. A language extremely difficult in itself, plus subject-matter altogether strange if not unintelligible, has caused the downfall of far too many pupils. The later stories cover a wider field, including mythology, both Greek and Roman, and Cæsarian episodes.

After the lessons is a summary of forms, and a short collection of Latin verses for memorizing at the teacher's discretion.

No one engaged in work of this kind can fail to realize his indebtedness to Dr. W. H. D. Rouse, the pioneer for the Direct Method in Latin. The authors count themselves especially fortunate in having as their colleague Dr. Carl A. Krause, whose enthusiastic and successful work in the Direct Method for Modern Languages has been a great inspiration to them in their efforts. They wish to express their grateful acknowledgments to Mr. Theodore C. Mitchill, Principal of the Jamaica High School, to Mr. Darwin L. Bardwell, District Superintendent assigned to High Schools in the New York City Department of Education, and to the New York State Examinations Board, whose support has made possible their testing of this method. They are likewise under special obligation to Professor 
Nelson G. McCrea of Columbia University for his encouragement and for certain detailed criticisms of the text; and to Miss Lydia F. Root, Mr. Roscoe A. Grant and Mr. Jacob Mann, their colleagues in the Classical Department, who have worked out the lessons in class and given many helpfül suggestions.

The Authors. 


\section{CONTENTS}

PAGE

Suggestions to the Pupll . . . . . . . . . . 2

\section{Pēnsa Discipulīs Cōnscrīpta}

I. Verba: Actīvum Praesēns, Imperātīvum et Indicātīvum. Fōrmula I Singulāris . . . . . . . 3

II. Verba: Actīvum Praesēns, Imperātīvum et Indicātīvum. Fōrmula I Plūrālis . . . . . . . . . 3

III. Nōmina: Accūsātīvus Singulāris. Fōrmula II Singulāris. . . . . . . . . . . . . 4 4

IV. Praepositiōnēs cum Accūsātīvō. Fōrmula III . . . 5

V. Nōmina et Prōnōmina: Accūsātīvus Plūrālis. Fōrmula II Plūrālis . . . . . . . . . . . . . . 6

VI. Verba: Activum Praesēns, İnfinitīivum. Ōrātiō Obliqua . . . . . . . . . . . 7

VII. Adiectiva cum Nōminibus Concordantia . . . . 9

VIII. Adiectīva Varia . . . . . . . . . . . . . 11

IX. Numerī. "Quantum Spatī et Quam Diū." "Quōmodo Diēs Mēnsēs Annōs Agāmus" . . . . . . . 12

X. Nōmina, Adiectīva, Prōnōmina: Casus Genetīvus Singulāris. Fōrmula IV . . . . . . . . . 14

XI. "Dē Puellā Illā Cucullō Rubrō Indūtā" . . . . . 15

XII. Nōmina, Adiectĩva, Prōnōmina: Casus Genetĩvus

Plūrālis. Fōrmula IV. . . . . . . . . . . . 17

XIII. "Dē Agricolā Fatuō" . . . . . . . . . . . . . . 18 
XIV. Verba: Actīvum Praeteritum Indieātīvum. Partēs Prīncipālēs . . . . . . . . . . . . 19 XV. Verba: Actīvum Praeteritum İnfīnītivvum. "Dē Volpe et Ūvīs" . . . . . . . . . . . 21

XVI. Nōmina, Adiectīva, Prōnōmina: Casus Datīvus. Fōrmula IV . . . . . . . . . . 22

XVII. "Dē Puerō Illō Quī in Nāve Flagrante Stābat" 24 XVIII. "Dē Tribus Vīlicīs" . . . . . . . . . . 25

XIX. Nơmina, Adiectīva, Prōnōmina: Casus Ablātīvus. Fōrmula IV . . . . . . . . . . . 26

XX. Casus Ablātīvus: Syntaxis . . . . . . . 27

XXI. "Dē Iōanne Illō et Vìte Fabālī" ..... . 29

XXII. Nōmina, Adiectīva, Prōnōmina. Casus Nōminātīvus . . . . . . . . . . . . 30

XXIII. "Dē Cane et Umbrā Eius." Sum. Possum . 32 XXIV. "Dē Mīlite Standiscō et Amōre Eius" . . . . 33 XXV. Nōmina, Adiectīva, Prōnōmina: Genus Neutrum . . . . . . . . . . . 35

XXVI. "Dē Cane et Bove." Fābula duōbus modīs scrīpta . . . . . . . . . . . 36

XXVII. Quaestiōnum et Respōnsōrum Cōnspectus . . 38 XXVIII. Verba: Vōx Passīva. Tempora Praesēns et Praeteritum .......... . 40

XXIX. Adiectīva: Comparātiō. "Dē Cane et Armāriō Vacuō"............. 41

XXX. "Dē Anū Quae in Soleā Vivēbat" . . . . . . 43

XXXI. Verba: Tempus Futūrum, Actīvum et Passī-

vum. Verba Dēpōnentia. Sum. Possum . 44

XXXII. "Dē Tỉbīcine Illō et Tỉbīis Eius" . . . . . . 46

XXXIII. Verba: Tempora Plūsquamperfectum et Futūrum Perfectum . . . . . . . . . . 47

XXXIV. "Dē Puerīs in Silvā Mortuīs." Quĩ . . . . . 49

XXXV. Verba: Tempus Imperfectum . . . . . 50

XXXVI. "Dē Geōrgiō et Cerasō" . . . . . . . . . 51

XXXVII. Verba: Indicātīvī et Īnfīnītīvī Cōnspectus . . 52

XXXVIII. Participia Verbōrum. Volō. Nōlō. Mālō . . 54 XXXIX. "Dē Phaethonte" . . . . . . . . 56 
XL. "Dē Proserpinā." I . . . . . . . . . . 57

XLI. Verba: Quacstiō Oblīqua. Fōrmula V. Subiūnctīvum Praesēns . . . . . . . . 58

XLII. "Dē Proserpinā." II . . . . . . . . . . . . 59

XLIII. Verba: Clausulae Finālēs. Fōrmula VI. Subiūnetīvum Imperfectum . . . . . . . . 60

XLIV. "Dē Proserpinā." III . . . . . . . . . . . . 62

XLV. Verba: Subiūnctīvum Perfectum et Plūsquamperfectum. Cum. Fōrmula VII . . . . . . 63

XLVI. "Dē Proeliō cum Nerviīs ā Caesare Factō." I . 65

XLVII. Clausulae Cōnsecūtĩvae. Cōnsecūtiō Temporum.

Fōrmula VIII . . . . . . . . . . . 66

XLVIII. "Dē Proeliō cum Nerviīs à Cacsare Factō." II . 67

XLIX. Ablātīvum Absolūtum. "Dē Larā" . . . . . 68

L. "Dē C. Iūlì Caesaris Rēbus Gestiss" . . . . . . 69

Appendix Grammaticus . . . . . . . . . 71

Pōmata . . . . . . . . . . . 81

INDEX VeRBōRUM . . . . . . . . . . . . 87

\section{PICTŪRAE}

Puella Cucullō Rubrō indūta et Avia . . . . . . . . . ad 16 Agricola Fatuus et Fundus Eius . . . . . . . . . . ad 18 Volpis et Üvāe. . . . . . . . . . . . . . . . ad 22 Puer et Nāvis Flagrans. . . . . . . . . . . . . ad 24 Iōannēs Vītis Fabālis Gigās . . . . . . . . . . ad 30 Canis Carō Carrus . . . . . . . . . . . . ad 32 Prīscilla et Nūptiae Eius . . . . . . . . . . . . ad 34 Magistrātūs Mūrēs Tībīcen . . . . . . . . . ad 46 Geōrgius Cerasus. . . . . . . . . . . . ad 52 Castra et Proelium Caesaris . . . . . . . . . ad 66 



\section{BEGINNERS' LATIN BY THE DIRECT METHOD}




\section{SUGGESTIONS TO THE PUPIL}

In studying and practising the lessons in this book, you must be sure to do the following things if you wish to succeed:

I. Keep the English words out of your mind entirely.

II. Always connect the Latin words, in your mind, directly with the act or thing which they represent.

III. Always commit to memory whatever your teacher tells you to learn, with absolute thoroughness, until you can recite and write it rapidly without a single error.

IV. You will learn how to use the Latin words and sentences by practice in class. Try hard to follow and understand whatever your teacher and classmates do, and watch for mistakes.

V. Always ask your teacher immediately about anything which you do not understand. .

VI. Always ask him for special help and practice when you feel yourself weak.

VII. Try to teach the lessons to those at home.

So long as you study hard, think in Latin, pay close attention and ask questions, you are on the road to success. 


\section{PĒNSUM I}

The first formula, printed below, shows how to give a command to a person, and also how to say what I am doing, what you are doing, what he or she is doing. Notice that the initial letters of the Latin words spell "first."

The words in the first column you use in giving a command to a person. Those in the second, third and fourth columns answer the questions:

Quid facis? Quid faciō? Quid facit?

Accipe fōrmulam Prīmam Singulārem:

Ferì! Feriō. Ferīs. Ferit.

Indue! Induō. Induis. Induit.

Rape! Rapiō. Rapis. Rapit.

Spectā! Spectō. Spectās. Spectat.

Torquē! Torqueō. Torquēs. Torquet.

\section{PĒNSUM II}

Below is Fōrmula $I$ in the plural, and below that are some new words. When we say vide is like torque we mean that to tell what we are doing we do not say 'vidīmus' nor 'vidāmus' but vidēmus.

Learn to say the formula without thinking of any English words; try always to make the act suggest directly the Latin word. 
The words in the first column are used in giving a command to two or more persons. Those in the second, third and fourth answer the questions:

Quid facitis? Quid facimus? Quid faciunt?

Accipe fōrmulam Prīmam Plūrālem:

Ferite! Ferimus. Feritis. Feriunt.

Induite! Induimus. Induitis. Induunt.

Rapite! Rapimus. Rapitis. Rapiunt.

Spectāte! Spectāmus. Spectātis. Spectant.

Torquēte! Torquēmus. Torquētis. Torquent.

Like torquē are vidē, abstergē.

Like indue are bibe, intende, ërige, pōne, tange, scrïbe, claude, surge.

Like rape are cape, fac (not face).

Like feri is aperi.

\section{PĒNSUM III}

In this formula you take up nouns. Notice that the initial letters of the Latin sentences spell "madame."

When we say, for instance, that sellam is like mappam, we mean that we do not say 'sellum' nor 'sellem,' but sellam:- and correspondingly with the other groups of words.

Always associate the Latin words, in your mind, directly with the act or the thing which they represent.

The nouns in this lesson answer questions like:

Quid torqueō? Quid bibis?

Quid intendimus? Quid ērigunt?

But your answer will not be complete unless you repeat the verb also, in the proper person and number. 
Fōrmulam Secundam Singulārem Habētis:

Mappam torquē! Mappam torqueō. Mappam torquēs, et c. Aquam bibe!

Digitum intende!

Aurem tange!

Manum èrige!

Effigiem vidē!

Like mappam are aquam, crētam, sellam, iānuam, puellam, mēnsam, fenestram.

Like aurem is parietem.

Like digitum are librum, puerum.

\section{PĒNSUM IV}

In this lesson you have prepositions. In studying the sentences remember how the acts naturally follow one another. Always try to connect the Latin sentences with the act; do your best to keep the English out of your mind.

These prepositional phrases answer the question

\section{Ubi?}

except that Ad and In answer the question

Quō? or Ad quid?

Fōrmulam Tertiam Habētis:

Trāns limen i!

In cellam veni!

Per cellam ambulā!

Contrā sellam stā!

Ad sellam i! 
Ante sellam stā!

Post sellam stā!

Circum sellam i!

Subter sellam stā!

Super sellam stā!

- Inter sellās stā!

Stā and ambulā are like spectā.

Venī is like feri.

$\overline{\mathbf{I}}$ is like no other word you know; here is its formula:

SINGULĀris: İ! Eō. İs. It.

Plưrālis: İte! İmus. İtis. Eunt.

\section{PĒNSUM V}

In this lesson you have nouns in the plural. When we said in Lesson III, that sellam, for instance, is like mappam, we meant also that in the plural the words are similarly alike. As we have 'mappās,' so we have sellās, or 'mēnsās,' not 'sellōs' nor 'mēnsūs.' If you do not understand 'aquās,' ask your teacher. (We cannot have 'crētam' in the plural at all because the Romans did not so use the word.)

You also have some pronouns; these have a spelling peculiar to themselves.

The nouns in this formula answer questions like

\section{Quae torqueō? Quae tangitis?}

Of the pronouns, quem and quōs are the questions, to which the others are the answers. Questions beginning with quae? or quid? (Pēnsum III) refer to things, not persons. 
Fōrmulam Secundam Plūrālem Habētis:

Mappās torquē!

Aquãs bibe!

Digitōs intende!

Aurēs tange!

Manūs ërige!

Effigiès vidē!

\section{Prōnōmina Habētis:}

Quem? Eum (eam); hunc (hanc); illum (illam); mē, tẽ, sẽ. Quōs? Eōs (eãs); hōs (hās); illōs (illās); nōs, vōs, sē.

\section{PĒNSUM VI}

I. When I do anything, and tell what I am doing (as for instance 'mappam feriō'), if for any reason you wish me to repeat my words, you may ask me, 'Quid dīcis?' and I will answer, 'Dīcō mē mappam ferīe.'

II. Similarly, if you perform the act, and I tellyou what you are doing ('mappam ferīs'), if you wish me to repeat my words, you may ask me, 'Quid dīcis?' and my answer will be, 'Dīcō tē mappam ferīre.'

III. Again, if Glabrio does the thing, and I tell what he does ('mappam ferit'), in case you wish me to repeat my words you may ask me, 'Quid dicis?' and I will answer, 'Dìcō Glabriōnem (or 'illum puerum') mappam ferïre' Or if Marcella tells what Glabrio 
does, and you want her words repeated, you may ask me, 'Quid dīcit?' and I will answer, 'Dīcit Glabriōnem mappam ferīe.'

IV. But if Glabrio does the thing and also says, 'Feriō,' then if you ask me or anyone to repeat Glabrio's words, the question of course will be, 'Quid dīcit?' and the answer will be, 'Dīcit sē mappam ferīre.' We could not now say, 'Dỉcit illum puerum ferire mappam,' for that would mean that Glabrio was telling us that someone else was doing it and not he himself.

V. In no case can a person say simply, 'Dīcō (or 'dīcis' or 'dīcit') ferīre,' for he would not be telling who did the thing. He must always put in some word like 'mē' or 'tē' or 'se' ' or 'illum' or something else to show clearly who performed the act, as, for example, 'Dīcō tē et Mārcum ferīre.'

VI. When I use 'dicō' (or any of the new verbs given below, and often 'videō') I must give the verb which goes with it a special form, - and this form never changes, no matter who or how many do the thing. For 'feriō' it is 'ferire'; the forms for the other verbs are given below at $B$.

A. Sequitur Fōrmula.

Respondet quaestiōnibus Quid dīcis?

vel Quid dīcō? vel Quid dīcit? et cēterīs.

Feriō. . . . . . . Dīcō mē ferīre.

Ferīs. . . . . Dīcō tē ferìre.

Ferit. . . . . . Dīcō illum (illam) ferïre.

"Feriō." . . . D Dicit sē ferīe. 
Ferìmus. . . . Dìcō nōs ferìre.

Ferīis. . . . Dìcō vōs ferìre.

Feriunt. . . . . Dìcō illōs (illās) ferìre.

"Ferimus." . . . Dỉcunt sè ferire.

B. Similēs Fōrmās - Ī NFīnītīva - ALiōrum VerBŌRUM HABĒMUS.

Feriō: ferìre; item aperīe et $c$.

Induō: induere; item intendere et $c$.

Rapiō: rapere; item capere et $\mathbf{c}$

Spectō: spectāre; item stāre et $\mathbf{c}$.

Torqueō: torquēre; item vidēre et $\mathbf{c}$.

Eō: ìre.

Exempla: Induō:- dīcō mẽ induere. Spectās:- dịcō tẽ spectäre.

C. Verba nova: dīc (sim. indue, sed dīc, nōn dīce): crēde (sim. indue): putā (sim. spectā): scìtō (sim. ferī), sed scìtō, nōn sci.

\section{PĒNSUM VII}

This lesson gives you some pronominal adjectives and some descriptive adjectives. It also tells you the gender of the nouns you have had thus far.

A. Adiectīya Prōnōminālia.

They answer the questions:

$\begin{array}{llll}\text { Quem? } & \text { Quam? } & \text { Quōs? } & \text { Quās? } \\ \text { Hunc } & \text { Hanc } & \text { Hōs } & \text { Hās } \\ \text { Illum } & \text { Illam } & \text { Illōs } & \text { Illās } \\ \text { Eum } & \text { Eam } & \text { Eōs } & \text { Eãs }\end{array}$


B. Adiećtĩva.

They answer the questions:

$\begin{array}{llll}\text { Quālem? } & \text { Quālem? } & \text { Quãlēs? } & \text { Quālēs? } \\ \text { Altum } & \text { Altam } & \text { Altōs } & \text { Altās } \\ \text { Humilem } & \text { Humilem } & \text { Humilēs } & \text { Humilēs } \\ \text { Longum } & \text { Longam } & \text { Longōs } & \text { Longās } \\ \text { Brevem } & \text { Brevem } & \text { Brevēs } & \text { Brevēs }\end{array}$

\section{Genera Nõminum:}

Manum, $f$. Aurem, $f . \quad$ Puellam, $f . \quad$ Librum, $m . \quad$ Effigiem, $f$. Parietem, $m$. Mappam, $f$. Digitum, $m$.

Aquam, $f$. Puerum, $m$.

Crētam, $f$.

Sellam, $f$.

Iānuam, $f$.

Mēnsam, $f$.

Fenestram, $f$.

I. If I ask you "Cuius generis est vōx crētam (or digitum)?" answer "Fèminìñ̄ generis est vōx crētam," or "Masculīnī generis est vōx digitum," etc.

II. If I ask you "Cūr fenestram longam et non fenestram longum dīcimus?" answer "Longam et nōn longum dīcimus, propterea quod fenestram fêminiñ $\bar{\imath}$ est generis, et adiectīvum longam, nōn longum, fēminīn $\bar{\imath}$ est generis,". etc.

III. If I ask you "Cūr manūs longās et nōn manūs longam dīcimus?" answer "Proptereā quod vōx manūs plūrālī est in numerō, et vōx longās, nōn longam, plūrālī in numerō est." 


\section{PĒNSUM VIII}

Adiectīva:

\begin{tabular}{llll} 
Quālem? & Quālem? & Quālēs? & Quālēs? \\
Utrum? & Utram? & Utrōs? & Utrās? \\
Bonum & Bonam & Bonōs & Bonās \\
Malum & Malam & Māōs & Malās \\
Parvum & Parvam & Parvōs & Parvās \\
Magnum & Magnam & Magnōs & Magnās \\
Celerem & Celerem & Celerēs & Celerēs \\
Lentum & Lentam & Lentōs & Lentās \\
Gravem & Gravem & Gravēs & Gravēs \\
Levem & Levem & Levēs & Levēs \\
Veterem & Veterem & Veterēs & Veterēs \\
Novum & Novạm & Novōs & Novās \\
Longum & Longam & Longōs & Longās \\
Brevem & Brevem & Brevēs & Brevēs \\
Altum & Altam & Altōs & Altās \\
Humilem & Humilem & Humilēs & Humilēs \\
Lātum & Lātam & Lātōs & Lātās \\
Angustum & Angustam & Angustōs & Angustās \\
Absentem & Absentem & Absentēs & Absentēs \\
Praesentem & Praesentem & Praesentēs & Praesentēs \\
Mundum & Mundam & Mundōs & Mundās \\
Sordidum & Sordidam & Sordidōs & Sordidās \\
Quem? & Quam? & Quōs? & Quās? \\
Hunc & Hanc & Hōs & Hās \\
Illum & Ilam & Iloōs & Ilās \\
Eum & Eam & Eōs & Eās \\
& & & \\
\hline
\end{tabular}




$\begin{array}{llll}\text { Meum } & \text { Meam } & \text { Meõs } & \text { Meãs } \\ \text { Tuum } & \text { Tuam } & \text { Tuōs } & \text { Tuās } \\ \text { Suum } & \text { Suam } & \text { Suōs } & \text { Suãs } \\ \text { Nostrum } & \text { Nostram } & \text { Nostrōs } & \text { Nostrãs } \\ \text { Vestrum } & \text { Vestram } & \text { Vestrōs } & \text { Vestrãs } \\ \text { Suum } & \text { Suam } & \text { Suōs } & \text { Suãs }\end{array}$

\section{PẼNSUM IX}

Ecce numerī et sententiae.

I. Numerōs Habēs:

Respondent quaestiōnī Quot?

Ūnum, Ũnam

Duōs, Duās

Trēs, Trēs

Quattuor
Quĩnque

Sex

Septem

Octō
Novem

Decem

Ūndecim

Duodecim

II. Sententiās ĒDisce:

(a) Quam diū labōrās? . . . Septem hōrās labōrō.

(b) Quantum spatī librum por-

tās? . . . . . . xii passũs librum portō.

(c) Quam altam mēnsam et

quam longōs stilōs ha-

bēs?........ Mēnsam duōs pedēs et dìmidium altam, stilōs septem ūnciās et dīmidium longōs habeō.

III. Quō Modō Diēs Mēnsēs Annōs Agās. Lege.

Octō hōrās dormīs. Sex vel septem hōrās labōrās: recitās, litterās scrībis, librōs legis, multās rēs ēdiscis. Duās hōrās cibum edis. Octō vel septem hōrās vel lūdis vel aliās rēs fúcis. Sīc diem agis. 
Per mēnsem vīgintī diēs ad lūdum commeās, decem 5 diēs fēriās habēs. Per annum x mēnsēs labōrās, duōs mēnsēs fēriās habēs. Sīe mēnsem et annum agis.

Octō annōs ad lūdum grammaticum, quattuor annōs ad lūdum superiōrem commeās. Multās rēs ad lūdum portās: librōs, aliōs quattuor ūnciās lātōs, aliōs quīnque 10 ūnciās lātōs: et rēgulam ūnum pedem longam: stilōs quoque et calamōs sex vel septem ūnciās longōs. Mēnsam habēs duōs pedēs et dìmidium altam, trēs pedēs longam, duōs pedēs lātam.

Iam dīc mihi, quam diū ad lūdum commeās? Quot 15 librōs habēs? Quam longōs stilōs habēs? Et quam diū labōrās?

IV. Novās Vōcēs Habēs. İnspice et TrānSCRİBe ACCŨRĀTISSIMĒ.

Litteram, litterās, $f$.

Ünciam, unciās, $f$.

Hōram, hōrās, $f$.

Rēgulam, rēgulās, $f$.

Fēriās, $f$.

Pedem, pedēs, $m$.

Mēnsem, mēnsēs, $m$.

Gradum, gradūs, $m$.

Passum, passūs, $m$.

Diem, diēs, $m$.

Rem, rēs, $f$.

Annum, annōs, $m$.

Lūdum, lūdōs, $m$.

Stilum, stilōs, $m$.

Calamum, calamōs, $m$.

Cibum, $m$.
Dormī

Scrībe

Lege

$\bar{E}$ disce

Lūde

Age

Ede

Recitā

Commeā

Portā

Labōrā

Multum, multam

Vìgintī

Grammaticum, grammaticam Superiōrem, superiōrem Alium, aliam

(Ferī)

(Indue)

(Spectā)

(2)




\section{PĒNSUM X}

In hōc pēnsō, sententiās in quīnque partēs dispositās habētis. Prīmae sententiae in ūnā quāque parte positae (exemplī grātiā, manum ērigō, aurem tangōo, et c.) quaestiōnī "quid?" respondent, et similēs sunt sententī̄s in Pēnsō III scrīptīs. Cēterae sententiae (e.g., manūs digitōs porrigō, auris pictūram spectō, et c.)

quaestiōnī novae Cuius? plērumque respondent

(sed īnspicite sententiās īnfrā scrīptās).

\section{Fōrmula IV (Qū̄eta):}

Manum ērigō.

Manūs digitōs porrigõ.

Aurem tangō.

Auris pictūram spectō.

Puellam videō.

Puellae mēnsam videō.

Librum teneō.

Librī pāginam legō.

Effigiem videō.

Effigiēī capillōs tangō.

Hās sententiās, sī nōn ēdiscitis, necesse est saepe perlegere.

A. Manūs brevis (longae) digitōs porrigō. Pedis brevis (longī) digitōs porrigō.

B. Meam manum ērigō; meōs librōs teneō. Tuās aurēs tangō; tuum pedem tangō.

Eius puerī (puellae) librum teneō. Illīus puerī (puellae) librum teneō. Huius puerī (puellae) librum tenē̄. Suam aurem tangit; suōs librōs tenet. 


\section{Quaestiōnēs et Respōnsa:}

I. Cuius? . . . (Huic quaestiōnī respondent sententiae in sectiōne "B" suprā scrīptae.)

II. Cuius? . . . Videō puerum possidēre librum: videō puerum, possessōrem libri.

Videō puellam scrībere fābulam: videō puellam, scrīptōrem fābulae.

III. Cuius? . . . Videō puellam advenīre: videō adventum puellae. Sentiō puerum timēre: sentiō timōrem puerī.

IV. Quālem? vel
Cuius? ... Papȳrum capiō, et saccum papỹrī faciō: cibum in hōc saccō pōnō; iam saccum cibì plēnum habeō.

V. Quālem? . . Librum gravem videō:

librum magnae gravitātis videō.

Discipulum stupidum habeō:

discipulum terribilis stupiditātis habeō.

VI. Quantum? . . . Nōn tōtum parietem, sed partem parietis spectō.

\section{PĒNSUM XI}

Fābulam nārrō. Attendite, et aurēs vestrās ērigite. Dìcō hanc fābulam quīnque partēs habēre.

I. Anum videō. Anum pauperem et miseram videō. Vîllam quoque huius anūs pauperis et miserae spectō. Crēdō hanc anum nōn bene vītam agere. Videō anum 5 in villam suam ìre, vīllae iānuam claudere. 
II. Iam puellam videō. Neptem illīus anūs videō. Cucullum rubrum induit: saccum alūtae capit, et cibum in saccō pōnit. Per viam magnam partem diēī per 10 silvam ambulat, et saccum cibì plēnum ad aviam suam portat.

III. Sed subitō - lupum videt, lupum magnum et terribilem; dīcō puellam lupum terribilis magnitūdinis vidēre. Nunc lupum latīnē dīcere audiō, "Salvē, pu15 ella: quō is?" et puellam respondēre, "Ad aviae villam hunc saccum cibī plēnum portō." Iam quid putātis lupum facere? Videt puellam cucullum rubrum possidēre - dīcō eum illam possessōrem cucullī rubrī spectāre. Dīcit sē possessōrem cucullī et cibī amāre: dīcit ${ }_{20}$ "Ō pulchra puella, amō tē. Dā mihi cucullum tuum." Et videō lupum cucullum capere et induere; et puellam subter arborem cōnsīdere.

IV. Iam quid putātis? Celeriter ad aviae vīllam it - dīcō lupum ìre - et anum reperit et - edit! Tum 25 puellam exspectat; dīcō lupum adventum puellae exspectāre. Et nōnne scītis puellam ad aviae vīllam celeriter venīre, et nōn aviam suam reperīre, sed cucullum et lupum terribilem invenīre?

V. Sed vēnātōrem venīre videt - adventum vēnā30 tōris spectat, et hunc virum lupum interficere videt; - mortem lupī spectat, et gaudet. Nōnne putātis vēnātōrem, servātōrem puellae, gaudēre? Et patrem et mātrem puellae gaudēre? Sed crēdō hōs dolēre quoque. Cür dolent? 

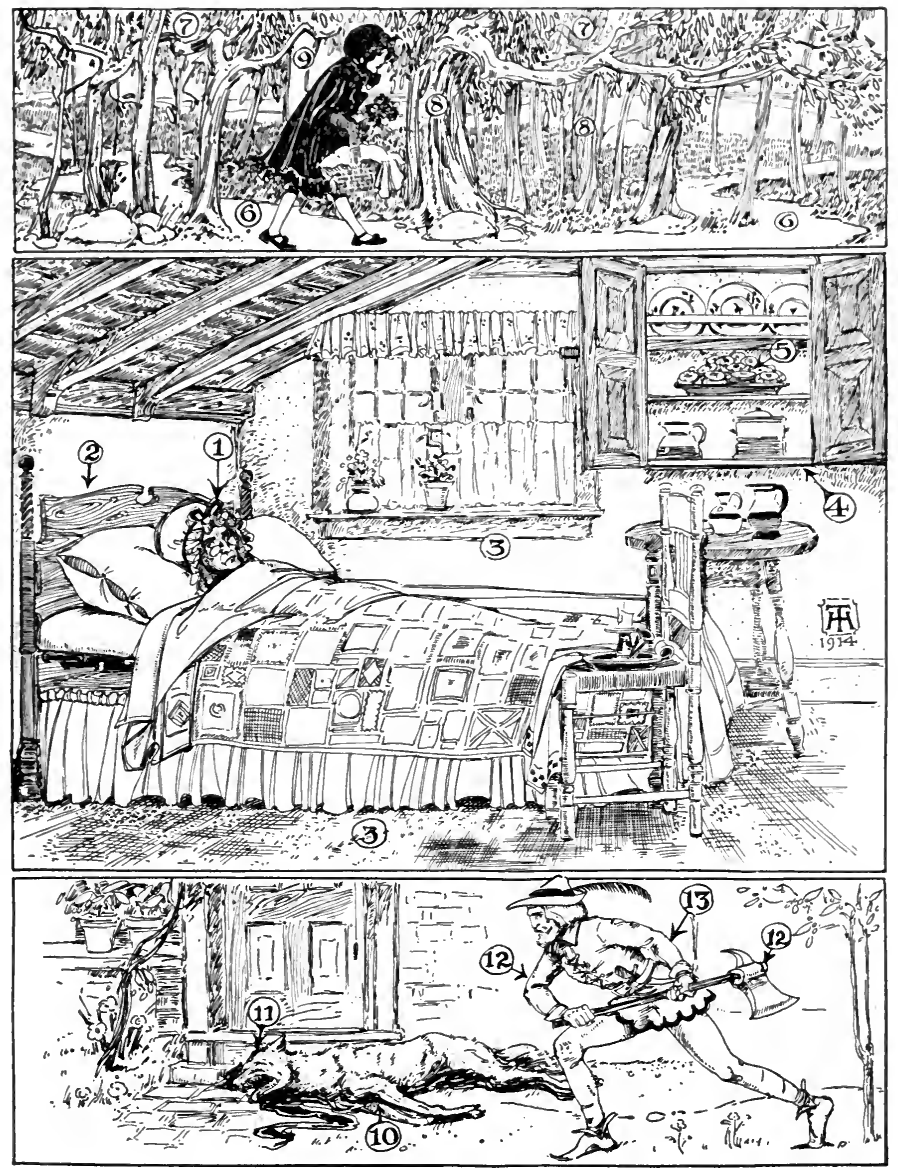

Puella Cucullō Rubrō Indūta et Avia

1. anus iacet. 2. lectulus. 3. villa. 4. armärium. 5. placentae. 6. via. 7. silva. 8. arbor. 9. cucullus. 10. lupus. 11. mors lupī. 12. lupus interficitur. 13. vēnātor. 



\section{PĒNSUM XII}

Habēmus iterum fōrmulās Pēnsī $X$, sed nunc in numerō plūrālī scrīptās. Novae sententiae quaestiōnī Quōrum? plērumque respondent.

Fōrmula IV (QuĀrta):

Manūs èrigō.

Manuum digitōs porrigō.

Aurēs tangō.

Aurium pictūram spectō.

Pedēs tangō.

Pedum plantās tangō.

Puellās videō.

Puellārum mēnsās videō.

Librōs teneō.

Librōrum pāginās legō.

Effigiēs videō.

Effigièrum capillōs tangō.

Hās sententiās, sĩ nōn êdiscitis, necesse est saepe perlegere.

A. Puellārum brevium (altārum) mēnsās videō.

Puellārum breviōrum mēnsās videō.

Librōrum brevium (longōrum) pāginās legō.

Librōrum breviōrum pāginās legō.

B. Nostrās manūs ērigimus.

Nostrum lūdum frequentāmus.

Vestram patriam amātis.

Vestrōs pedēs tangitis.

Eōrum (puerōrum) librōs tenēmus.

Eārum (puellārum) librōs tenēmus. 
Illōrum (puerōrum) librōs tenēmus.

Illārum (puellārum) librōs tenēmus.

Hōrum (puerōrum) librōs tenēmus.

Hārum (puellārum) librōs tenēmus.

Suās manūs ērigunt.

Suum lūdum frequentant.

\section{PĒNSUM XIII}

I. Fundum videō, fundum parvum et malum; dīcō hunc fundum angustōs agrōs habēre, et malās herbās et arborēs paucās et humilēs, et malōs frūctūs; dīcō mē fundum magnae sterilitātis vidēre. Num tū illum 5 fundum possidēre vīs? Nōn crēdō.

II. Sed dīcō agricolam illum fundum possidēre. Et iam agricolam videō; possessōrem huius sterilis fundī, et hārum sterilium arborum spectō. Ėheu, nōn gaudeō; doleō; miseret mē huius infēlīis agricolae. Sed 10 cūr putās hunc agricolam tam malum fundum habēre? Ego sciō. Numquam labōrat, semper somniat. Nōnne intellegis?

III. Sed videō agricolam sē commovēre. Quō it? Ad arborēs venit, paucōs frūctūs carpit (dīcō agricolam 15 arborum frūctūs, nōn herbārum frūctūs, carpere), et in corbe suō frūetūs pōnit. Tum hunc corbem frūctuum plēnum capit, et per viam ambulāre incipit. Quid volt? Crēdō agricolam velle ad urbem ire et corbem frūctuum plēnum vēndere.

20 IV. Sed quid facit? Ad arborem venit, subter arborem cōnsĩdit, ante sē corbem illum frūctuum plēnum 


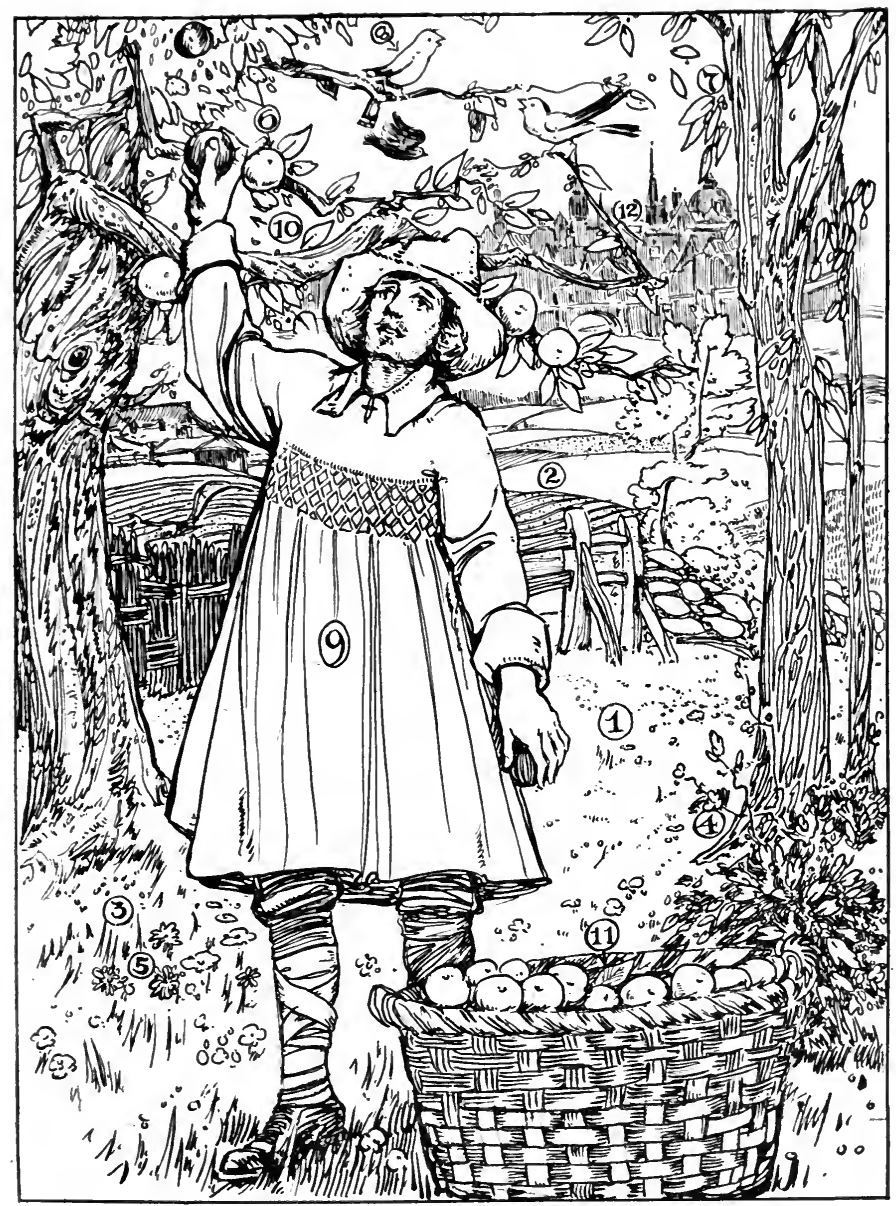

Agricola Fatude et Fundus Eius
1. fundus.
2. ager.
3. 4. herbae.
5. flōrēs.
6. frūctus.

7. frondēs. S. avis. 9. agricola. 10. frūetum carpit. 11. corbis. 12. urbs. 
pōnit, oculōs claudit, dormit. Ō pessimum agricolam! Iam somniat sē ad tabernam mercātōris amīcī pervenīre, et frūctūs illōs vēndere. Sē iam multōs nummōs habēre putat (dīcō agricolam putāre sē magnam pe- 25 cūniam habēre).

V. Nōnne putās agricolam crēdere sē bene vītam agere? Sed auscultā. Dīcō agricolam nunc somniāre sē uxōrem pulchram dūcere, et sē uxōrem mīrābilis pulchritụdinis habēre. Putat sē faciem uxōris (vel pul- 30 chritūdinem faciēī) amāre, sed linguam uxōris et vōcēs mordācēs nōn omnīnō amāre. Somniat sē uxōrem ferīre! Sed rē vērā corbem ferit, et sīc meritō corbem illum frūctuum plēnum et nummōs et fundum et uxōrem āmittit.

VI. Iam dīcite mihi, ō discipulī et discipulae, sī lēctiōnēs vestrās nōn ēdiscitis, — sī nōn labōrātis, sed dormītis et somniātis, - quid?

\section{PĒNSUM XIV}

Sì pēnsum tuum, heri male scrīptum, hodiē bene corrigis, tibi dīcō, "Bene hodiē scrībis, sed male heri scrīpsistī."

Eōdem modō dīcimus: "Hodiē, - nunc scrībō: heri, - antehãc scrīpsī," vel "nunc scrībunt, antehāc scrīpsērunt." Itaque partem Fōrmulae Secundae Singulāris habēmus. Quaestiōnēs sunt:

Quid fēcistī? Quid fēcī? Quid fēcit? et c.

Mappam

mappam torsī, torsimus, torsisti, torsistis, torsit, torsērunt. 


$\begin{array}{llll}\text { Aquam } & \text { bibi, } & \text { bibistī, } & \text { bibit, } \\ \text { aquam } & \text { bibimus, } & \text { bibistis, } & \text { bibērunt. } \\ \text { Manum } & \text { èrēxī, } & \text { ērēxistī, } & \text { ērēxit, } \\ \text { manum } & \text { èrēximus, } & \text { èrēxistis, } & \text { ērēxērunt. }\end{array}$

Necesse est magistrum tuum tibi fōrmam ūnīus cuiusque verbī latīnī dīcere quae quaestiōnī "Quid antehāc fēcistī?" et c. respondet. İnfrā hanc fōrmam multōrum verbōrum scrīpsimus. Hae omnēs fōrmae similēs sunt verbō vel fōrmae torsī et c.

\begin{tabular}{|c|c|c|}
\hline Nunc & DīCō MẼ & ANTEHÄC \\
\hline $\begin{array}{l}\text { Feriō, } \\
\text { Induō, } \\
\text { Rapiō, } \\
\text { Spectō, } \\
\text { Torqueō, } \\
\text { Sūmō, } \\
\text { Pōnō, } \\
\text { Faciō, } \\
\text { Capiō, } \\
\text { Aperiō, } \\
\text { Eō, } \\
\text { Dícō, } \\
\text { Putō, } \\
\text { Sciō, } \\
\text { Habeō, } \\
\text { Labōrō, } \\
\text { Agō, } \\
\text { Portō, } \\
\text { Teneō, } \\
\text { Reperiō, } \\
\text { Exspectō, } \\
\text { Veniō, } \\
\text { Respondeō, } \\
\text { Cōnsīdō, }\end{array}$ & $\begin{array}{l}\text { Ferïre: } \\
\text { Induere: } \\
\text { Rapere: } \\
\text { Spectāre: } \\
\text { Torquēre: } \\
\text { Sūmere: } \\
\text { Pōnere: } \\
\text { Facere: } \\
\text { Capere: } \\
\text { Aperīre: } \\
\text { İe: } \\
\text { Dīcere: } \\
\text { Putāre: } \\
\text { Scīre: } \\
\text { Habēre: } \\
\text { Labōrāre: } \\
\text { Agere: } \\
\text { Portāre: } \\
\text { Tenēre: } \\
\text { Reperīre: } \\
\text { Exspectāre: } \\
\text { Venïre: } \\
\text { Respondēre: } \\
\text { Cōnsīdere: }\end{array}$ & $\begin{array}{l}\text { Percussī. } \\
\text { Induĩ. } \\
\text { Rapuī. } \\
\text { Spectāīi. } \\
\text { Torsī. } \\
\text { Sūmpsī. } \\
\text { Posuī. } \\
\text { Fēcī. } \\
\text { Cēpī. } \\
\text { Aperuī. } \\
\text { İi. } \\
\text { Dīxī. } \\
\text { Putāvī. } \\
\text { Scīvī. } \\
\text { Habuī. } \\
\text { Labōrāvī. } \\
\text { Ẽgī. } \\
\text { Portāvī. } \\
\text { Tenuī. } \\
\text { Repperī. } \\
\text { Exspectāvī. } \\
\text { Vēnī. } \\
\text { Respondī. } \\
\text { Cōnsēdī. }\end{array}$ \\
\hline
\end{tabular}




\begin{tabular}{|c|c|c|}
\hline $\begin{array}{l}\text { Doleō, } \\
\text { Vēndō, } \\
\text { Āmittō, } \\
\text { Intellegō, } \\
\text { Commoveō, } \\
\text { Incipiō, } \\
\text { Volō, }\end{array}$ & $\begin{array}{l}\text { Dolēre: } \\
\text { Vēndere: } \\
\text { Āmittere: } \\
\text { Intellegere: } \\
\text { Commovēre: } \\
\text { Incipere: } \\
\text { Velle: }\end{array}$ & $\begin{array}{l}\text { Dolūi. } \\
\text { Vēendidī. } \\
\text { Āmīsī. } \\
\text { Intellēxī. } \\
\text { Commōvī. } \\
\text { Coepì. } \\
\text { Voluī. }\end{array}$ \\
\hline
\end{tabular}

\section{PẼNSUM XV}

A. Sī mappam ferīs, et dīcis, "Mappam feriō," et sī ego ā tē quaerō, "Quid dīcis?" tū mihi respondēs, "Dīcō mē mappam ferīre." Quod sī nōn nunc ferīs, sed antehāc (vel heri, vel ōlim) mappam percussistī, tum respondēs, "Dìcō mē mappam percussisse." Iam putō tē hanc fōrmulam satis bene intellegere:

Mappam percussī: dīcō mē mappam percussisse.

Mappam induistĩ : dīcō tē mappam induisse.

Mappam rapuit: dīcō eum mappam rapuisse.

Ṁappam spectãvimus: dīcō nōs mappam spectāvisse.

Mappam torsērunt: dīcō eōs mappam torsisse.

B. Fābulam cucullī rubrī iam audīvimus. Agricolae fatuĩ quoque fābulam perlēgistis. Sed fābulam volpis et ūvārum nōndum nārrāvĩ. Dīcō hanc volpem cibum dēsīderāvisse sed nihil cibī habuisse. Itaque per partem silvae ad hortum magnae fertilitātis iit crēdō volpem cucurrisse - et repperit (dīcō volpem repperisse) nōn arborēs et herbās sed vītēs viridēs et ūvās rubrās magnae pulchritūdinis magnaeque dulcēdinis. Quis vestrum numquam audīvit volpēs magnum amōrem ūvārum dulcium habēre? 
Ad altam vitem igitur iit et subter vìtem stetit dīcō hanc iēiūnam volpem subter racēmōs ūvārum stetisse et ūvās suspexisse, et dēsīderāsse. Tum quid fēcit? Exsiluit. Cūr exsiluit? Voluit ūvās capere. Sed neque 15 cēpit ūvās neque tetigit. Cūr nōn? Nōn satis longōs lacertōs putō eam habuisse. Tum dīcō nostram volpem doluisse et lacrimāvisse, et dīxisse sē pessimē .• vìtam agere. Ēheu, miseram volpem! Tum subter rāmōs vìtis cōnsēdit, et ūvās illās dulcissimās super sē 20 spectāvit, et dēsīderāvit eās cadere. Sed nōn cecidērunt. Tum īram nōn continuit, et exclāmāvit hanc malam vìtem nōn dulcēs sed acerbās ūvās tulisse sēque eās neque umquam dēsīderāvisse neque nunc dēsīderāre. Sīc abiit.

\section{PẼNSUM XVI}

Fōrmulam IV iterum vidētis, sed novae sententiae additae sunt. Hae novae sententiae

$$
\text { quaestiōnī Cui? aut Quibus? respondent. }
$$

$\bar{E}$ discite summā cum cūrā et novās sententiās et tōtam fōrmulam.

Manum ërigō.

Manūs digitōs porrigō.

Manui manum impōnō.

Aurem tangō.

Auris pictūram spectō.

Aurī plāgam inflīgō.

Pedem tangō.

Pedis plantam tangō.

Pedĩ rēgulam suppōnō.
Manūs èrigō.

Manuum digitōs porrigō.

Manibus manūs impōnō.

Aurēs tangō.

Aurium pictūram spectō.

Auribus plāgās innfligōo.

Pedēs tangō.

Pedum plantās tangō.

Pedibus rẽgulam suppōnō. 


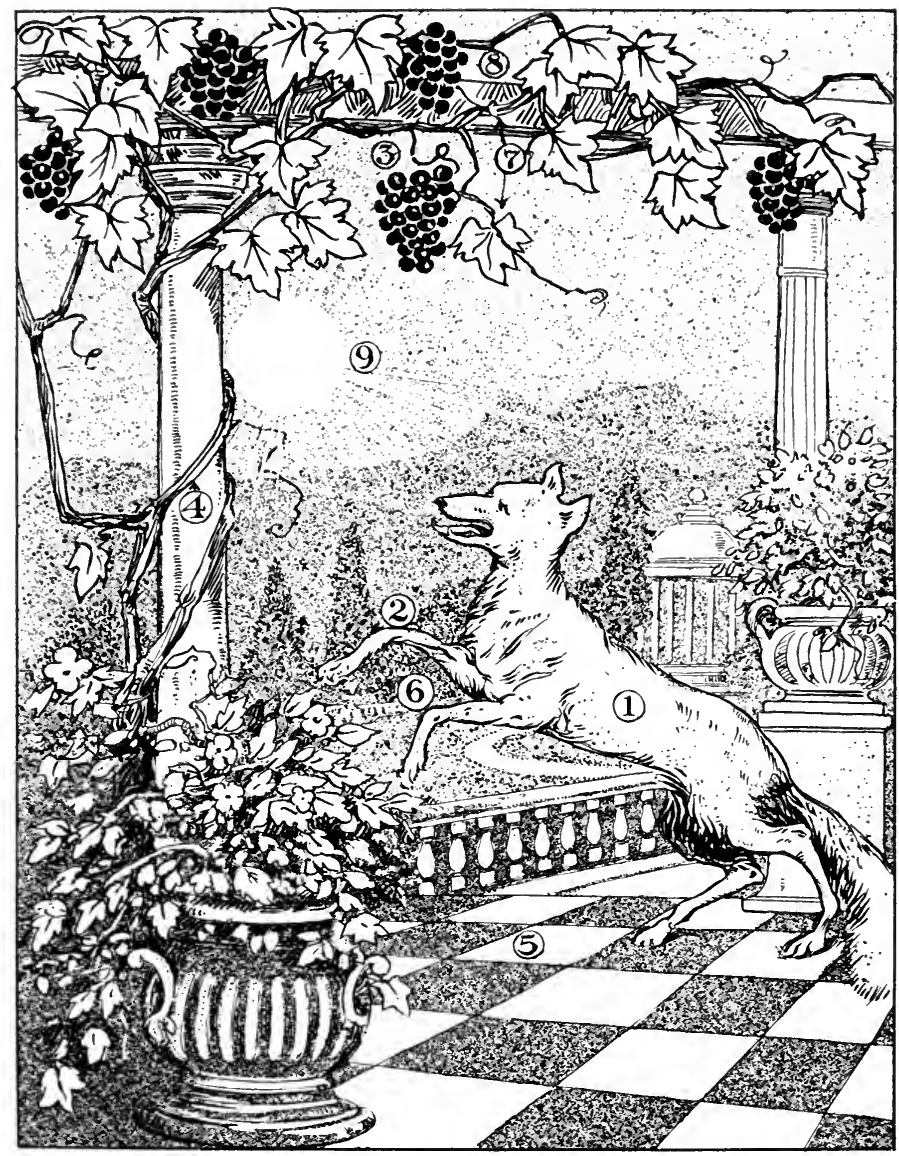

Volpis et Ũvae

1. volpis. 2. volpis exsilit. 3. ūvae. 4. vītis. 5. hortus. 6. lacertī. 7. racēmus. 8. rāmus. 9. sōl. 


\section{.}


Puellam videō.

Puellae mēnsam videō.

Puellae nummum dō.

Librum teneō.

Librī pāginam legō.

Librō pāginam addō.

Effigiem videō.

Effigiēī capillōs tangō.

Effigiēī immineō.
Puellās videō.

Puellārum mēnsās videō.

Puelliss nummōs dō.

Librōs teneō.

Librōrum pāginās legō.

Librīs pāginās addō.

Effigiēs videō.

Effigiērum capillōs tangō.

Effigiēbus immineō.

Hās sententiās, sī nōn ēdiscitis, necesse est saepe perlegere.

A. Manuī brevī (longae) plāgam īnflīgō.

Pedī brevī (longō) plāgam īnflīgō.

Mihi plāgam īnflīgō.

Tibi plāgam înflīgō.

Eì (puellae, puerō) plāgam ìnflīgō.

Illī (puellae, puerō) plāgam inflīgō.

Huic (puellae, puerō) plāgam inflīgō.

Sibi plāgam inflīgit.
Manibus brevibus (longīs) plāgās īnflīgō.

Pedibus brevibus (longīs) plāgās īnflīgō.

Nōbīs plāgās īnflīgimus.

Vōbīs plāgās īnflīgimus.

Eìs (puellīs, puerīs) plāgās īnflīgō.

Illīs (puellīs, puerīs) plāgās īnflīgō.

Hīs (puellīs, puerīs) plāgās īnflīgō.

Sibi plāgās īnflīgunt.

B. Tibi imperō: mihi pārēs. Mihi librum fers: tibi pēnsum dō. Illī rem nārrās: tibi crēdit. Tibi persuādet: illī cōnfīdis.

Vōbis favēmus: nōbis studētis. Nōbis nocētis: vōbis ignōscimus.

C. I. Ego tibi classem committō: tē discipulīs praeficiō. Tũ discipulīs praees et classī praestās.

II. Dīcō classem cūrae esse tibi.

III. Et sī stupidam classem habēs, dolōrem quoque habēs, et dīcis classem stupidam dolōrī esse tibi.

IV. Nōn tē sed tibi occurrō.

Tè discipulīs ostendō, sed tibi librum ostendō, fortasse.

Tibi rem prōpōnō, vel classī tē magistram prōpōnō. 


\section{PĒNSUM XVII}

Fābulam trīstem vōbīs nārrō. Pugnam mạnam videō - pugnam nāvium longārum et nautārum fortium. Dỉcō hās nāvēs et hōs nautās illīs nāvibus et nautīs plāgās gravēs înflixisse, et ignem eīs iniēcisse.

5 Iam omnēs illās nāvēs flagrāre videō. Quis vestrum nōn scit ignem et nāvibus et hominibus nocēre? Nōnne tibi nocet?

Iam imperātōrem illārum nāvium videō - dīcō hunc virum nautīs imperāre, et classem cūrae illī esse. Et 10 fĩlium eius videō; audiō hunc puerum nāvēs et pugnās nāvālēs amāre; dīcō eum rēbus nāvālibus studēre. Atque puerum pium sciō mē vidēre; nam sciō hunc puerum semper patrī suō pārēre et cōnfīdere. Id temporis fîliō suō dīxit - dīcō patrem dīxisse - "Cōnsiste hīe 15 ante mālum nāvis. Dīcō flammās nōbīs imminēre, sed crēde mihi, tibi nōn nocent. Nōlī timēre." Sīc fīliō persuāsit - dīcō hunc virum fīliō persuāsisse, et fîlium ante mālum stetisse.

Nunc mortem patris videō, sed sciō illīus mortem 20 fỉlium nōn vĩdisse. At flammās puerō illī appropinquāre videō. Timet, sed nōn sē commōvet. Patrī cōnfīdit et pāret. " $\bar{O}$ mī pater," exclāmāvit, "nōnne scīs flammās mihi paene nocuisse? Nōnne licet mihi discēdere?" Nūllam audīvit vōcem. Et iterum, "Ō pa25 ter," conclāmāvit, "ignōsce mihi, necesse est mē abīre. Sōlum mē relīquistī. Calōrem flammārum sentiō. Semper antehāe mihi fāvistī. Cūr nōn nunc mihi venīs? Cūr nōn mihi parcis? Cūr nōn mihi discedēre permittis? Cūr nōn -" At mortem puerī subitam et 


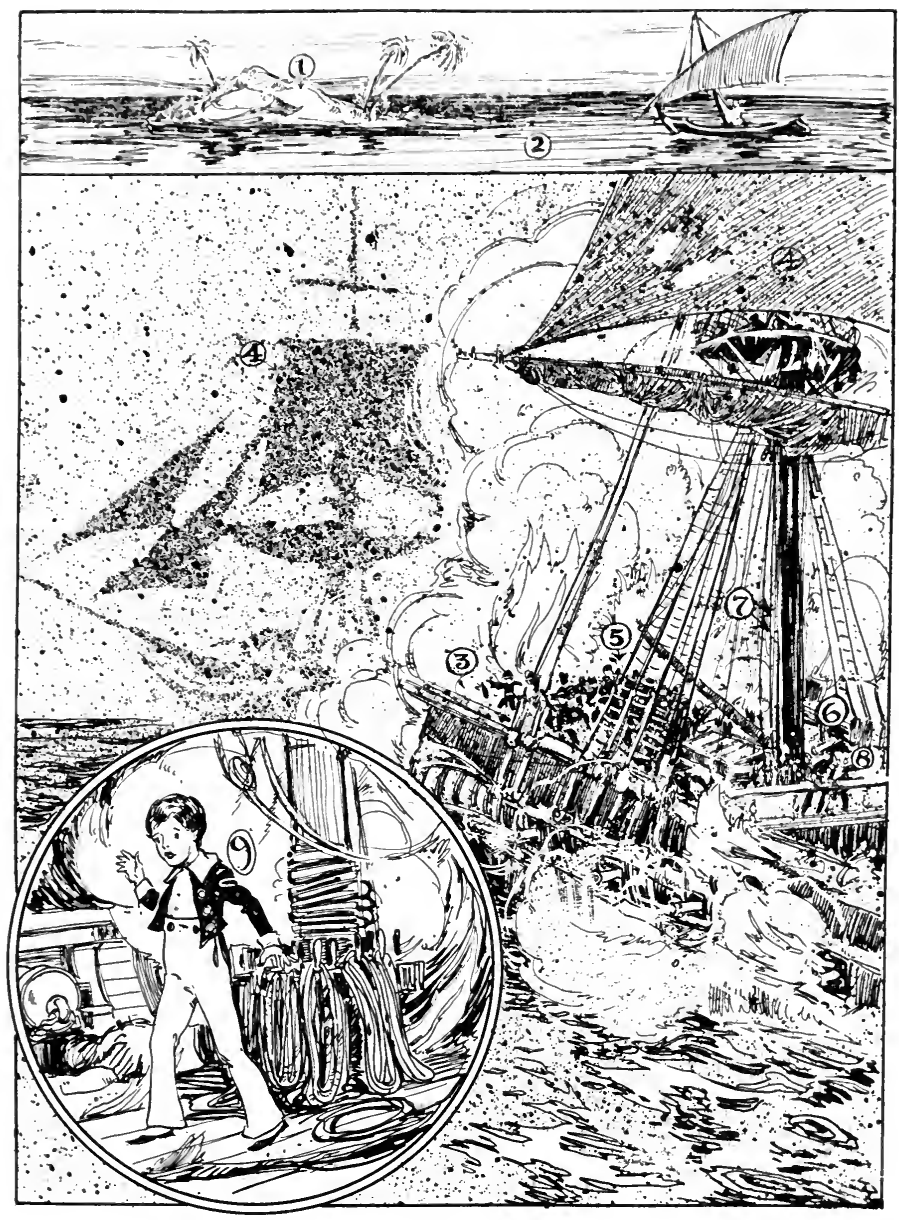

Puer et Nāvis Flagrāns

1. insula. 2. mare. 3. pugna. 4. nāvis. 5. nautae. 6. imperātor. 7. mālus. 8. puer. 9. ignis post puerum. 
terribilem videō! Èheu puerum fortem et pium! Sem- 30 per tibi laudem propter fortitūdinem pietātemque tribuimus.

\section{PẼNSUM XVIII}

Fābulam agricolae fatuī iam audīvimus. Nunc fābulam vīlicōrum trium audīte. Dīcō agricolam sapientem et dīvitem multōs fundōs habuisse, et tribus servīs ad rem idōneīs quondam ostendisse sterilitātem hōrum fundōrum dolōrī sibi esse. Itaque dīxit eīs, 5 "Tē, Mārce, sex fundīs praeficiō; tibi, Claudī, trēs fundōs committō; tē, Tiberī, ūnī fundō praepōnō. Vōs omnēs vĩlicōs meōs et cūrātōrēs rērum meārum faciō. Arboribus, frūctibus, būbus, servīs meīs omnibus praeestis. Volō eōs cūrae vōbīs esse. Volō fundōs meōs 10 quaestuĩ mihi esse, et magnam pecūniam mihi parāre. Iam valēte." Et discessit (dīcō agricolam - vel dominum - abiisse et vĩlicōs suōs relīquisse).

Tum dīcō prīmum illum vīlicum et secundum quoque dīligenter labōrāvisse, sed Tiberium nihil fēcisse; 15 et multōs post annōs dominum eōrum (id est, agricolam illum) subitō rediisse eīsque occurrisse, et dīxisse, "Fundīs meīs praeestis. Quid mihi habētis?" Tum dīcō Māreum et Claudium nummōs innumerōs dominō ostendisse, et respondisse, "Fundōs tuōs nōbīs com- 20 mīsistī; hanc pecūniam dīcimus nōs tibi parāvisse." "Bene fēcistis," respondit; "grātiās vōbīs agō maximās. Tibi, Mārce, fīliam meam dō uxōrem, atque quīnque bonōs fundōs; tibi, Claudī, quattuor fundōs magnae fertilitātis." 
"Sed tū, Tiberī, quid mihi habēs?" "Fundum tantummodo tuum," respondit. "Nōnne pecūniam mihi fēcistī? Nōnne labōrāvistīi?" "Nōn labōrāvī, nam timuī. Dĩxī tê mihi ūnum tantummodo fundum com30 mīsisse, magnam pecūniam postulāvisse. Itaque nihil fēcî." "Ō pessime tū et piger, cūr nōn labōrāstī? Vel cūr nōn servōs tuōs iussistī agrōs colere pecūniamque tibi facere? Heus, servī, comprehendite eum, in carcerem abdūcite, plāgās gravissimās ei innflīgite. At tuīs 3 fundīs, Claudī, huius scelerātĩ hominis fundum addō."

\section{PĒNSUM XIX}

Iam habuistis Casum Accūsātivum, Casum Genetīvum, Casum Datīvum. In hōe pēnsō novam partem Fōrmulae IV, Casum Ablātīvum discitis.

Manum èrigō.

Manūs digitōs porrigō.

Manuī manum impōnō.

In manū librum habeō.

Aurem tangō.

Auris pictūram spectō.

Aurī plāgam īnflīgō.

Sub aure digitum intendō.

Pedem tangō.

Pedis plantam tangō.

Pedī rēgulam suppōnō.

Sine pede vix ambulō.

Puellam videō.

Puellae mēnsam videō.

Puellae nummum dō.

À puellā crētam accipiō.
Manūs ērigō.

Manuum digitōs porrigō.

Manibus manūs impōnō.

In manibus librōs habeō.

Aurēs tangō.

Aurium pictūram spectō.

Auribus plāgās inflīgō.

Sub auribus digitōs intendō.

Pedēs tangō.

Pedum plantās tangō.

Pedibus rēgulam suppōnō.

Sine pedibus nōn ambulō.

Puellās videō.

Puellārum mēnsās videō.

Puellīs nummōs dō.

A puellīs crētam accipiō. 
Librum teneō.

Libri pāginam legō.

Librō pāginam addō.

É librō chartam capiō.

Effigiem videō.

Effigiēī capillōs tangō.

Effigiēī immineō.

Prō effigiē pecūniam dō.
Librōs teneō.

Librōrum pāginās legō.

Librīs pāginās addō.

Ẽ librīs chartās capiō.

Effigiēs videō.

Effigiērum capillōs tangō.

Effigiēbus immineō.

Prō effigiēbus pecūniam dō.

Sententiās īnfrā scrīptās nōn necesse est ēdiscere, sed summā cum cūrā iterum iterumque perlegere.

In manū brevī (mundiōre) In manibus brevibus (mundiō(longā) librum habeō.

$\overline{\mathrm{E}}$ librō brevī (mundiōre) (longō) chartam capiō.

$\overline{\mathrm{A}} \mathrm{mē}$ crētam accipis.

$\bar{A}$ tē crētam accipiō. ribus) (longīs) librum habeō.

Ex eō (librō) chartam capiō.

Ex illö (hōc) chartam capiō.

Ab eā (puellā) crētam accipiō.

Ab illā (hāc) crētam accipiō.

Dē sē librum iacit.

Cum eō (illō) (hōc) ambulō.

Mēcum puerum dūcō.

Tēcum puerum dūcis.

Sēcum puerum dūcit.

$\overline{\mathrm{E}}$ librīs brevibus (mundiōribus) (longīs) chartās capiō.

$\bar{A}$ nōbis crētam accipis.

$\overline{\mathrm{A}}$ vōbīs crētam accipiō.

Ex eīs (librīs) chartās capiō.

Ex illis (hīs) chartās capiō.

Ab eīs (puellìs) crētam accipiō.

Ab illis (hìs) crētam accipiō.

Dē sē librōs iaciunt.

Cum eìs (illis) (hìs) ambulō.

Nōbīscum puerum dūcimus.

Vōbiscum puerum dūcitis.

Sēcum puerum dūcunt.

\section{PẼNSUM XX}

Explicantur in hōc pēnsō variī ūsūs Casūs Ablātīvī. Dūcimus vōs ad ūnum quemque ūsum per vocābula et sententiās in pēnsīs priōribus plērumque quidem iam explicātās. Variae sunt quaestiōnēs quoque quibus respondent. 
I. . . (Quot hōrās dormiō? Octō hōrās dormiō. - Pēnsum IX.)

Quandō? . . . . . Prīmā hōrā surgō.

II. . . (Inter librī pāginās chartam videō, eamque capiō). Unde? $\bar{A}$ quō? . . . . . Ē librō chartam capiō. - Pēnsum XIX.

$\bar{A}$ puellā crētam accipiō.

III. . . . (Sī puerum feriō, vidētis mē manum meam ad puerum movēre.)

Quō (inștrūmentō)? . . Manū puerum feriō.

IV. . . . (Dīcō puerum celerem esse . . . Dìcō puerum celeriter ad iānuam īre.)

Quōmodo? . . . . . Cum celeritāte ad iānuam it. Magnā celeritāte ad iānuam it.

Magnā cum celeritāte ad iānuam it.

V. . . (Manum porrigō, librumque capiō.)

Ubi? . . . . . . In manū, non in faucibus, librum habeō. - Pēnsum XIX.

VI. . . (Magnum librum lentē tollō.)

Cūr? . . . . . Proptereā quod magnum librum tollō, lentē tollō.

Propter magnitūdinem, lentē tollō. Magnitūdine, lentē tollō.

VII. - . (Discipulum terribilis stupiditātis habeō.

Discipulum mīrābilis brevitātis habeō.) - Pēnsum $\mathrm{X}$.

Quālem? . . . . . Discipulum terribili stupiditāte habeō.

Discipulum mīräbilem nōn altitūdine sed brevitāte et stupiditāte habeō. 


\section{PĒNSUM XXI}

In librō vetere hanc fābulam lēgī, puerum Iōannem nōmine ōlim à sene parvō et brevĩ fabās singulārī pulchritūdine accēpisse, et iussū senis, mediā nocte, in hortō, ante vīllam suam, eās sēvisse, duōs annōs maximā cum dīligentiā coluisse, tamen nē parvam quidem stipulam vīdisse.

Sed ultimō diē alterius annī, māne ē lectulō surrēxit, iānuam aperuit, permagnam vītem fabālem mīrābilis altitūdinis cōnspexit. Cōnfirmō hanc vītem ā terrā multōs passūs usque ad nūbēs sē ērēxisse. Tum 10 dīcō senem iuvenī iterum occurrisse. "Cape," inquit, "hunc longum cultrum; sine timōre ascende." Statim sen̄i pāruit - mementō iuvenem cultrum excēpisse, manibus pedibus ascendisse, ad summam vītem pervēnisse.

Illō locō terram incognitam, in ultimā parte terrae montem altum, sub monte aedēs magnās ante sē vīdit. Illūc magnā celeritāte properat, subitō auribus suīs sonitum terribilem audit, gigantem horribilī vultū ex aedibus ad sē festīnāre videt, cultrum dextrā manū 20 corripit, inimīcō occurrit, pugnam cum eō committit, plāgam mortiferam gigantī cultrō suō inflīgit, eum interficit. Tum in aedēs iniit, multōs nummōs aureōs repperit, puellam pulcherrimam catēnīs gravibus revinctam invēnit, eam resolvit, ex aedibus dūxit, mag- 25 nam vim pecūniae sēcum portāvit.

Iam ad vītem ambulāre coepērunt; subitō alium gigantem prōspexērunt. Tum statim videō adulēscentem sinistrā manū puellam nummōsque excipere, dex- 
30 trā cultrum dēstringere, ad vìtem currere, per vìtem ad terram dēscendere, vītem secūrī dēcīdere. Iam quid restat? Nōnne scìtis adulēscentem tōtō animō puellam amāvisse, eam uxōrem dūxisse, ambōs semper posteā beātam vìtam ēgisse? — Nunc plaudite!

\section{PĒNSUM XXII}

Hōe pēnsō Casum Nōminātīvum doceō. Partēs singulae huius pēnsī partibus singulīs Fōrmulae IV respondent, id est: in parte prīmā vidētis omnia genera vocābulōrum vōcābulō "Manum" similia: in parte secundā omnia vōcābulō "Aurem" similia: et cētera. Infrā sunt Prōnōmina et Adiectīva.

Quaestiōnēs sunt:

$$
\begin{gathered}
\text { Quis? (Quī -? Quae -?) } \\
\text { Quid? (Quod -?) } \\
\text { Quī? (Quī -? Quae -?) } \\
\text { Quae? (Quae -?) }
\end{gathered}
$$

Dīcō manum (manūs) tremcre. Manus tremit. Manūs tremunt.

Dīcō aurem (aurēs) audīre.

Dìcō hominem (hominēs) spīrāre.

Dīcō arborem (arborēs) virēre. Dīcō gravitātem crēscere.

Dìcō altitūdinem crēscere.

Dīcō mātrem (mātrēs) amāre.

Dīcō parietem (parietēs) stāre.

Dìcō mentem (mentēs) cogitāre.

Dỉcō vōcem (vōcēs) sonāre.
Auris audit. Aurēs audiunt. Homō spīrāt. Hominēs spīrant.

Arbor viret. Arborēs virent. Gravitās crēscit. Altitūdō crēscit. Māter amat. Mātrēs amant. Pariēs stat. Parietēs stant. Mēns cogitat. Mentēs cogitant.

Vōx sonat. Vōcēs sonant. 


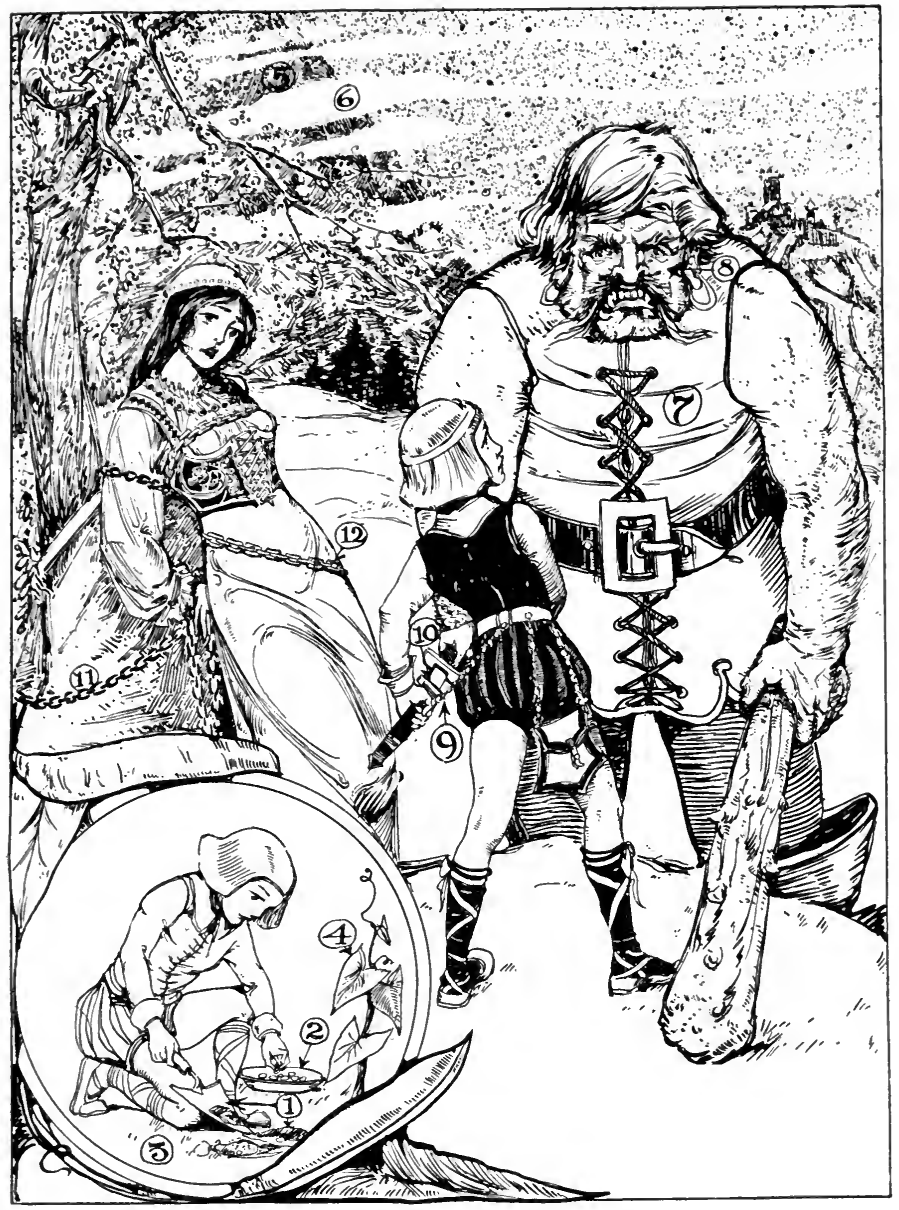

\section{Iōannēs Vĩtis FabĀlis Gigās}

1. puer serit. 2. fabae. 3. terra. 4. stipula. 5. mōns. 6. nūbēs. 7. gigās. 8. voltus crūdēlis. 9. 10. puer cultrum dēstringit. 11. 12. puella catēnīs revīneta. 
Dìcō bovem (bovēs) mūgīre. Dīcō urbem (urbēs) manēre. Dìcō pedem (pedēs) dolēre.

Dīeō puellam (puellās) lūdere.

Dỉcō librum (librōs) iacēre.

Dīcō puerum (puerōs) labōrāre. Dìcō virum (virōs) vigilāre.

Dīcō digitum (digitōs) indicāre.

Dīcō effigiem (effigiēs) cadere

Dìcō mē (nōs) docēre.

Dīcō tē (vōs) discere.

Dīcō eum (eōs), eam (eās) spectāre.

Dīcō illum (illōs), illam (illās) spectāre.

Dìcō hunc (hōs), hanc (hās) spectāre.

Dīcō celerem puerum (puellam) gaudēre.

Dìcō celerēs puerōs (puellās) gaudēre.

Dīcō brevem puerum (puellam) dolēre.

Dīcō brevēs puerōs (puellās) dolēre.

Dīcō.veterem equum (equam) iacēre.

Dīcō veterēs equōs (equās) iacēre.

Dīcō absentem puerum (puellam) dolēre. Dìcō audacem puerum (puel- Audax puer (puella) gaudet. lam) gaudēre.
Bōs mūgit. Bovēs mūgiunt. Urbs manet. Urbès manent. Pēs dolet. Pedēs dolent.

Puella lūdit. Puellae lūdunt.

Liber iacet. Librī iacent. Puer labōrat. Puerī labōrant. Vir vigilat. Virī vigilant.

Digitus indicat. Digitī indicant.

Effigiēs cadit. Effigiēs cadunt. (Ego) docē̄. (Nōs) docēmus. (Tū) discis. (Vōs) discitis. (Is, ea) spectat. (Ei, eae) spectant.

(Ille, illa) spectat. (Illi, illae) spectant.

(Hic, haec) spectat. (Hi, hae) spectant.

Celer puer (celeris puella) gaudet.

Celerēs puerī (puellae) gaudent.

Brevis puer (puella) dolet.

Brevēs puerī (puellae) dolent.

Vetus equus (equa) iacet.

Veterès equĩ (equae) iacent.

Absēns puer (puella) dolet. 
Dīcō bonum puerum (bonam puellam) gaudēre.

Dīcō bonōs puerōs (bonās puellās) gaudēre.

Dīcō miserum puerum (miseram puellam) dolēre.

Dīcō miserōs puerōs (miserās puellās) dolēre.

Dīcō pigrum puerum (pigram puellam) dolēre.
Bonus puer (bona puella) gaudet.

Bonī puerī (bonae puellae) gaudent.

Miser puer (misera puella) dolet.

Miserī puerī (miserae puellae) dolent.

Piger puer (pigra puella) dolet.

\section{PẼNSUM XXIII}

Haec fābula antīqua est sed crēdō eam nōn antīquiōrem esse quam cēterās. Canis parvus in viā stat. Hunc canem parvum anus crūdēlis possidet. Putō hanc anum crūdēlem can̄̄ cibum nōn dedisse. Iam 5 canis ēsurit, sed illī nihil cibī dat domina. Longa hōra trānsit. Iēiūnus fuit, sed nunc multō iēiūnior est. Nōnne crēditis eum iēiūniōrem esse? Secunda hōra longior est quam prīma, et tertia longissima omnium est, sed nihil eĩ dat domina. Quis vestrum dominam 10 crūdēliōrem quam eam vīdit? Ego dīcō illam crūdēlissimam omnium dominārum esse.

Merīdiēs (id est, media pars diēī) venit, et lanius quoque venit. Hic homō carrum et multam carnem habet; carnem vēndit. Canis miser - canem misèriō-

15 rem numquam vīdistis; miserrimum omnium canum eum esse crēdō - canis noster hominem illum (id est, lanium) in aedēs magnās inīre videt. Carnem celeriter ex carrō rapit, edere incipit. Canis minor eī occurrit et lātrat, sed nōn terret canem nostrum. 


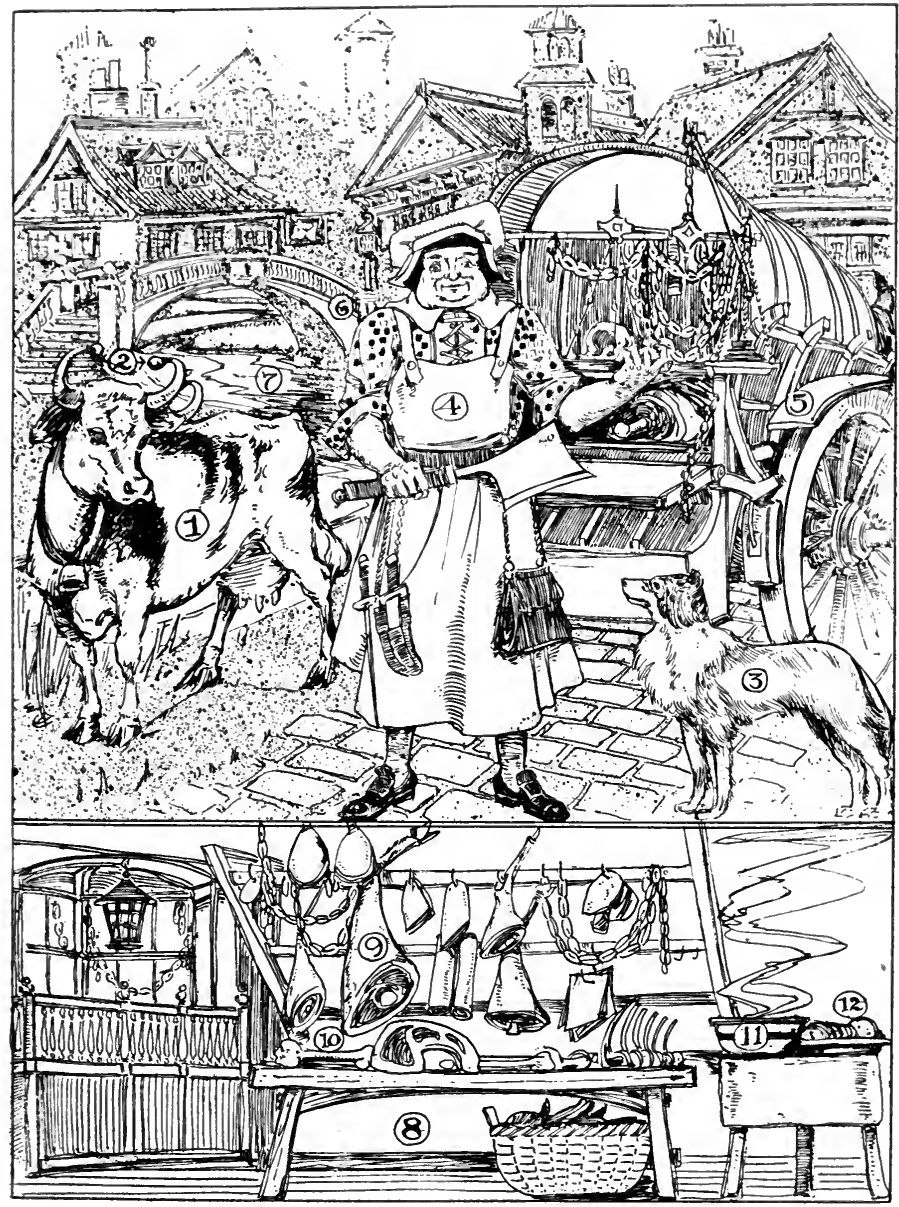

Canis Carō Carrus

1. bōs. 2. duo cornua. 3. canis. 4. lanius. 5. carrus. 6. pōns. 7. flūmen. 8. taberna. 9. carō. 10. os. 11. iūs. 12. pānis. 

Subitō canis maior advenit, et eum maiōrem canem 20 timet hic canis. Cibum suum faucibus excipit, ex timōre per viās maximā cum celeritāte currit. Mox ad pontem parvum venit, magnum illum canem nōn iam videt, in ponte stat, aquam spectat, in aquā sē maximum canem et maximam carnem vidēre crēdit. Fau- 25 cēs aperit et lātrat. Sīc-canis carnem āmittit.

Hĩc Tempus Praesēns ét Partēs Prĩncipālès Dūōum Verbōrum Habētis:

Sum. Es. Est. Sumus. Estis. Sunt.

Sum: esse: fui.

Possum. Potes. Potest. Possumus. Potestis. Possunt. Possum: posse: potui.

\section{PĒNSUM XXIV}

Multōs ante annōs Pūritānī Novam Angliam incoluērunt. Imperātōrem summā virtūte habuērunt; hunc virum illūstrem - circiter $\mathrm{xxxx}$ annōs nātus fuit - Mīlitem Standiscum cīvēs suī appellāvērunt, proptereā quod mīles optimus fuit. In vīcō quōdam hu- 5 ius terrae habitāvit virgō, pulchra modesta sapiēns. Prope xx annōs nāta fuit, sed optimē rēs domesticās intellēxit optimēque gessit, semper tēlās texuit. Nōnne in librīs vestrīs dē Prīscillā lēgistis?

Hanc virginem Mīles ille amāvit, eamque uxōrem 10 dūcere voluit, nihil tamen eĩ dē hāe rē dīxit. "Mē nōn hostēs," inquit, "sed mulierēs semper terrent. Sermō enim meus rudis et incompositus est, neque illī puellae persuādēre possum. Sed magna mē tenet spēs mē id per amīcum meum Iōannem Aldēnum efficere 15 
posse. Est ille iuvenis cōmis et ērudītus, illī nūlla resistere potest mulier." Statim iuvenem iussit ad puellam īre, causam suam prō sē dīcere; tum discessit exercitumque in Indōs dūxit.

20 At adulēscēns ipse tōtō animō Prīscillam dīlēxit adamāvitque, et scīvit puellam ipsam sē quoque adamāre. Sed Mīlitī suō fidēlis fuit amīcus; lacrima illī ex oculō excidit; sed sine morā ad virginis villam ìvit, eam prō amīcō obsecrāvit. "Imperātor fortis et audāx est; om25 nis gēns Indica eum timet. Homō illūstris et honestus, vir optimus benignissimus amantissimus est. Nōnne eum amās? Nōnne eĩ nūbere vīs?" At huic puella, "Cūr nōn prō tēe ipsō," inquit, "Iōannes, aliquid bonī dīcis?" Vix amōrem suum continēre potuit, amīcitiae

30 causā tamen - nōnne Iōannem fidēlem Standiscō suō amīcum fuisse dīxī? - sē retinuit. Ex vîllā ruit, diēs noctēsque per silvās errāvit, lacrimāvit, sē nōn diūtius vīvere posse exclāmāvit.

Nunc subitō rūmor per urbem parvam it, cīvēs vō35 cēs terribilēs audiunt, "Dux noster mortuus est! Ducem illūstrem Mìlitem Standiscum interfēcērunt Indī!" Iōannēs rēctā viā ad Prīscillam properat. " $\bar{O}$ mea Prīscilla," exclāmat, "doleō quod amīcum benignissimum amantissimumque āmīsis! Sed gaudeō - cūr nōn? -

40 nam nunc lỉberātī sumus. Iam tē in aeternum meam esse cōnfirmō, mē tuum esse." Et illa, "Deus ipse nōs coniūnxit. Ubi tū Iōannēs, ego Prīscilla."

Nunc ad ecclēsiam eunt, amīcī laetī conveniunt, clēricus illīs adest, eōsque virum coniugemque dēclārat. 45 Sonitum audiunt, ad forēs sē omnēs convertunt, in foribus cōnspiciunt-ipsum Mïlitem Standiscum! At ille, 


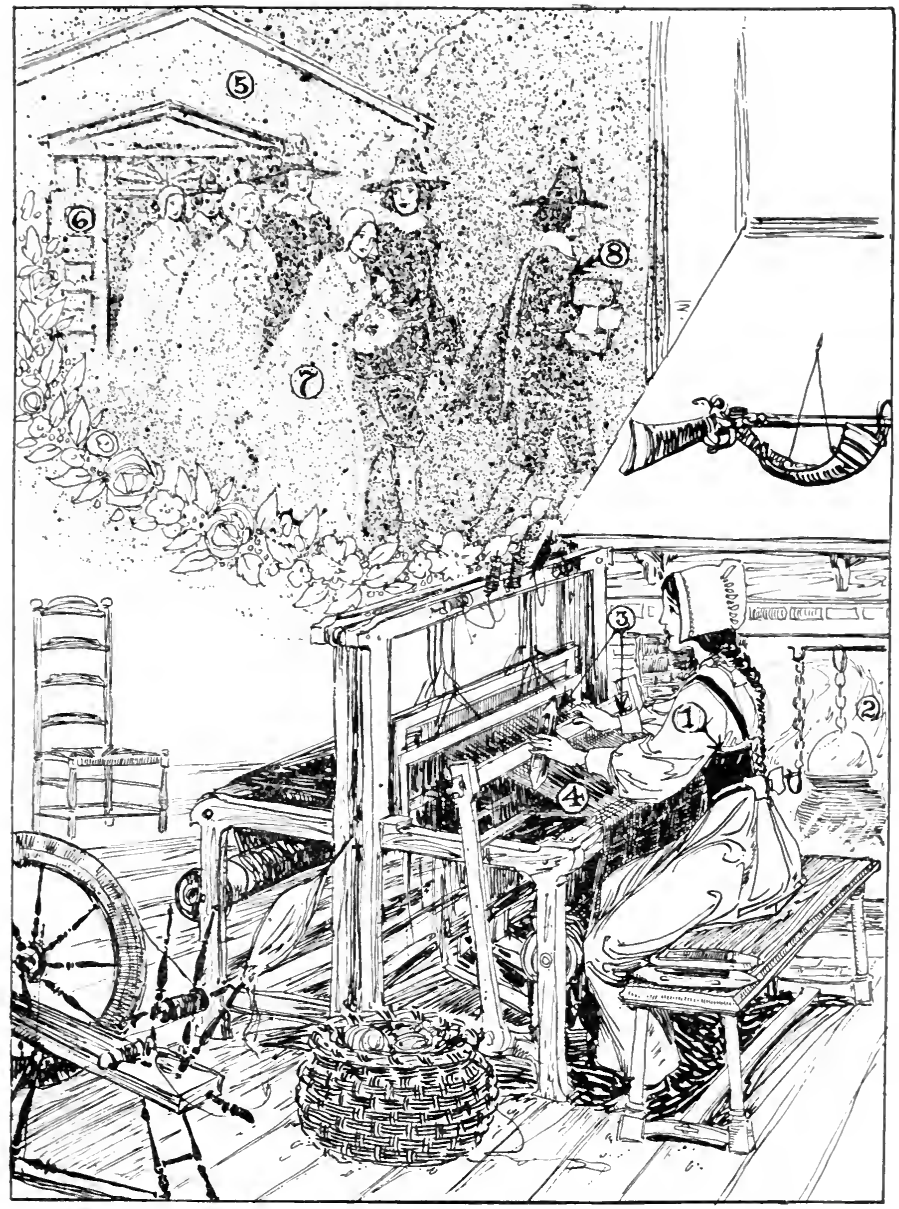

Prīscilla et Nūptiae Eius

1. zōna. 2. focus. 3. tēxit. 4. tēlae. 5. ecclēsia. 6. forēs. 7. pompa. 8. clēricus. 

"Nōlīte timēre," inquit, "nōn umbram vidētis. Nōn mē interfēcērunt Indī, sed volnerāvērunt, et ex manibus eōrum effūgī. Sed tū, mī Iōannes, tūque ō optima omnium puellārum Prīscilla — nune cognōscō mē stul- 56 tum ineptumque fuisse. Numquam decuit mē tē uxōrem dūcere. Sed vōs in perpetuum fēlīeēs, lactī, beātī este. Iam salvēte et valēte!" Hoc dīxit, manūs illīs benignē imposuit, iterum discessit. Itaque per silvās ad aedēs eōrum Iōannem Prīscillamque omnēs 55 dēdūxērunt.

Sīc per silv(am) Anglam prōcessit $\operatorname{pomp}(\mathrm{a})$ hymenaea.

\section{PĒNSUM XXV}

Fōrmulās Neutrī Generis in Hōc Pēnsō VidēTIS. ËDiscite.

I. Hoc vocābulum breve litterās habet.

Hoc vocābulum breve legō.

Huius vocābulī brevis litteram dēmōnstrō.

Huic vocābulō brevī litteram addō.

Ex hōc vocābulō brevī litteram capiō.

Haec vocābula brevia litterās habent.

Haec vocābula brevia legō.

Hōrum vocābulōrum brevium litterās dēmōnstrō.

Hìs vocābulīs brevibus litterās addō.

Ex hīs vocābulīs brevibus litterās capiō.

$\begin{array}{clll}\text { II. Illud } & \text { volnus } & \text { longum } & \text { sanguinem habet. } \\ \text { Illud } & \text { volnus } & \text { longum } & \text { spectō. } \\ \text { Illius } & \text { volneris } & \text { longī } & \text { partem tangō. } \\ \text { Illī } & \text { volnerī } & \text { longō } & \text { plāgam nōn infligōo } \\ \text { Ex illō } & \text { volnere } & \text { longō } & \text { cultrum rapiō. }\end{array}$




\begin{tabular}{|c|c|c|c|c|}
\hline & Illa & volnera & longa & sanguinem habent. \\
\hline & Illa & volnera & longa & spectō. \\
\hline & Illōrum & volnerum & longōrum & partem tangō. \\
\hline & Illīs & volneribus & longīs & plāgās nōn inflīgō. \\
\hline Ex & illìs & volneribus & longìs & cultrōs rapiō. \\
\hline III. & Id & animal & altius & cornua habet. \\
\hline & Id & animal & altius & spectō. \\
\hline & Eius & animālis & altiōris & cornua tangō. \\
\hline & Eī & animālī & altiōrì & cibum dō. \\
\hline $\mathrm{Ab}$ & eō & animālī & altiōre & cibum āmoveō. \\
\hline & $\mathbf{E a}$ & animālia & altiōra & cornua habent. \\
\hline & $\mathrm{Ea}$ & animālia & altiōra & spectō. \\
\hline & Eōrum & animālium & altiōrum & cornua tangō. \\
\hline & Eìs & animālibus & altiōribus & cibum dō. \\
\hline $\mathrm{Ab}$ & eìs & animālibus & altiōribus & cibum āmoveō. \\
\hline IV. & Ūnum & genū & supplex & est. \\
\hline & Ūnum & genū & supplex & habeō. \\
\hline & Ūnīus & genūs & supplicis & partem tangō. \\
\hline & Ūnì & genū & supplicī & plāgam inflīgō. \\
\hline Sub & ūnō & genū & supplicī & librum teneō. \\
\hline & Duo & genua & supplicia & sunt. \\
\hline & Duo & genua & supplicia & habeō. \\
\hline & Duōrum & genuum & supplicium & partem tangō. \\
\hline & Duōbus & genibus & supplicibus & plāgās inflìgō. \\
\hline Sub & duōbus & genibus & supplicibus & librum teneō. \\
\hline
\end{tabular}

\section{PĒNSUM XXVI}

I. In hāc fābulā nōnnūlla vocābula habēmus nova. Haec nōmina et prōnōmina et adiectīva non similia sunt eīs nōminibus et prōnōminibus et adiectīvīs quae in pēnsīs priōribus ūsurpantur. Summā dīligentiā animadvertite. 
II. Animal quoddam nōbīs nōn ignōtum per oppidum celebre currit. Per tōtum itineris spatium ad vetus aedificium accēdit ubi ūnum maius animal habitat. Hoc animal duo cornua habet, sed nōn ferum est. Illud minus animal igitur ante aedificium stat et 10 lātrat. Animal cornūtum nōn attendit. Mox venit animal hūmānum et claustra aperit. Animālī maiōrī frūmentum portat. Nunc intrat etiam nostrum ācre animal et iterum lātrat. Proelium permagnum committunt, et minimum illud animal cornibus huius 15 maximì volnus accipit. Bonum fuit initium, sed miserum est exitium animālis parvī.

III. Illa omnia vocābula neutrī sunt generis; et fortasse ea nōn intellegitis. Hās sententiās igitur inspicite; prīma ex hīs sententiīs idem sig- 20 nificat ac prīma fābulae praecēdentis; secunda idem ac secunda; et cēterae eōdem modō.

IV. Canis nōbīs nōn ignōtus per vīcum celebrem currit. Per tōtam viam ad aedēs veterēs accēdit ubi habitat ūna bōs maior quam ipse. Haec bōs cornūta $2 \overline{5}$ est, sed fera nōn est. Et ille canis - minor est quam illa bōs - ante aedēs stat et lātrat. Bōs cornūta nōn attendit. Mox homō venit, et forēs aperit. Bovī cibum portat. Nunc intrat etiam noster ācer canis et iterum lātrat. Pugna permagna est, et bōs canem vol- 30 nerat. Bene coepit canis, sed miserrima fuit mors illius. 


\section{PẼNSUM XXVII}

Hīc vocābula interrogātīva vidētis, et vocābula vel sententiās quae hīs vocābulīs respondent. Haec secundum ōrdinem casuum ōrdināta sunt.

A. I. . . . (a) Quis? (b)

Quī? . . . (a) Puer scrïbit. (b) Puellae stant. (XxII)

II. . . . (a) Quid? (b)

Quae? . . (a) Effigiēs manet. (b) Mappae iacent. (XXII)

B. I. . . . (a) Quem? (b)

Quōs? . . . . (a) Puerum, tē videō. (b) Puel-

II. . . Quō? Quam

in partem?

Quem ad locum? Ad

quem? . . . . Ad iānuam, in lūdum, ad tē cō. lās, nōs videō. (III, v)

(Iv)

III. . . Q Quam altum?

Quam lon-

gum? Quam

lātum? . . Decem pedēs, ūnam ūnciam longum est. (IX)

IV. . . Quantum spa-

tĩ? . . . . xx passūs ambulō. (Ix)

V. . . Quam diū? . . . (Per) tōtam hōram, xıI mēnsēs labōrō. (Ix)

C. I. . . . Quālem? Quā-

lēs? . . . . G Gravem librum, gravēs librōs.

(viI)

vel librum (librōs) magnae gravitãtis. $\quad(\mathrm{x})$

vel librum (librōs) magnā gravitāte tollō. (xIx, $\mathrm{xx})$ 
II. . . . Cuius? Quōrum? . . . (a) Meum, puellae librum teneō. (b) Nostram, puerōrum mēnsam tangō. ( $\mathrm{v} n 11, \mathrm{x})$

III. . . . Quantum? . . . Nōn tōtum parietem, sed partem parietis abstergeō. (x)

D. . . . . . Cui? Quibus? (a) Aurī, manūī, plāgam înflīgō. (b) Puerīs, puellīs, crētam dō. (xvi)

E. I. . . . Quandō? . . . . Octāvā hōrā, nunc surgō; heri surrēxī. (xıx, $\mathrm{xx})$

II. . . . Unde? . . . . . Ex corbe chartam capiō; ā iānuā abēo. (xix, xx)

III. . . . Quō (instrumentō)? Quibus (instrumentīs)? . . Manū, nōn pedibus, scrībō. $(\mathrm{xIx}, \mathrm{xx})$

IV. . . . Quōmodo? . . . Maximā (cum) celeritāte, celeriter scrībō. (xIx, xx)

V. . . Ubi? . . . . In mēnsā librum videō; ante

VI. . . . Cūr? Quā dē sellam stō. (xIx, $\mathrm{xx}, \mathrm{IV})$

causā? Quam-

obrem? . . . . Proptereā quod brevēs lacertōs habet, vel propter brevitātem lacertōrum, vel brevitāte lacertōrum, ūvās nōn tangit. (xIx, $\mathrm{xx})$

F. . . . Quot? . . . Multī, Multōs, Multōrum, Multīs

Multae, Multās, Multārum, Multis

Multa, Multa, Multōrum, Multīs

Decem, III, xxviII. (Ix) 


\section{PẼNSUM XXVIII}

Sì mappam feriō, mappa ā mē ferītur; sī mappam ferīs, mappa à tē ferìtur; sī mappam feriunt, mappa ab illīs ferìtur; si mappās ferītis, mappae à vōbīs feriuntur. Īnfrā habētis fōrmulās Fōrmulae I persimilēs; illūstrant Vōcem Passīvam.

\section{Quaestiō est: Quid fit?}

\section{Tempus Praeseñs:}

Nunc mappa feritur. Nunc mappa induitur. Nunc mappa rapitur. Nunc mappa spectātur. Nunc mappa torquētur.

Dìcō mappam ferìrī. Dìcō mappam induī. Dīcō mappam rapī. Dīcō mappam spectārì. Dìcō mappam torquērī.
Nunc mappae feriuntur. Nunc mappae induuntur. Nunc mappae rapiuntur. Nunc mappae spectantur. Nunc mappae torquentur.

Dìcō mappās ferīrì.

Item . . .

Sī mappam percussī, mappa ā mē percussa est; sì librum percussistī, liber $\bar{a}$ tē percussus est; sī animal percussērunt, animal ab illīs percussum est; sī puerōs ferītis, puerī à vōbīs feriuntur; sī puerōs percussistis, puerī $\bar{a}$ vōbīs percussī sunt.

\section{Quaestiō est: Quid factum est?}

\section{Tempus Praeteritum:}

Antehãc mappa percussa est,

puer percussus est, animal percussum est.
Antehāc mappae percussae sunt, puerī percussī sunt, animālia percussa sunt. 
Antehāc mappa indūta est. Antehāc mappa rapta est.

Antehāc mappa spectāta est. Antehāc mappa torta est.

Dicō mappam percussam esse, puerum percussum esse, animal percussum esse.

Dīcō mappam indūtam esse. Dīcō mappam raptam esse. Dícō mappam spectātam esse. Dícō mappam tortam esse.
Antehāc mappae indūtae sunt. Antehāc mappae raptae sunt. Antehāc mappae spectātae sunt. Antehāc mappae tortae sunt.

Dícō mappās percussās esse, puerōs percussōs esse, animālia percussa esse.

Dīcō mappās indūtās esse. Dỉcō mappās raptās esse. Dìcō mappās spectātās esse. Dícō mappās tortās esse.

In Pēnsō XIV partēs prīncipālēs verbōrum habētis. Sed omne ferē verbum quattuor partēs habet, quārum quārta est Participium Praeteritum Passīvum. Hoc participium in Pēnsō XIV nōn appāruit, sed in hōc pēnsō prīmum vidētis. İnfrā omnēs iv partēs prīncipālēs verbōrum Fōrmulae I scrīptae sunt, ut exempla sint.

$\begin{array}{llll}\text { Feriō } & \text { Ferīre } & \text { Percussī } & \text { Percussum } \\ \text { Induō } & \text { Induere } & \text { Induī } & \text { Indūtum } \\ \text { Rapiō } & \text { Rapere } & \text { Rapuī } & \text { Raptum } \\ \text { Spectō } & \text { Spectāre } & \text { Spectāīi } & \text { Spectātum } \\ \text { Torqueō } & \text { Torquēre } & \text { Torsī } & \text { Tortum }\end{array}$

\section{PĒNSUM XXIX}

Iterum iterumque hās sententiās perlegite, atque èdiscite.

Lentus puer lentē labōrat, Lentior puer lentius labōrat, Lentissimus puer lentissimē labörat.

Celer puer celeriter labörat, Celerior puer celerius labōrat, Celerrimus puer celerrimē labörat. 
Bona puella bene labōrat, Melior puella melius labörat, Optima puella optimē labōrat.

Mala puella male labörat, Peior puella peius labōrat, Pessima puella pessimē labōrat.

Facilis lëctiō facile ēdiscitur, Facilior lēctiō facilius ēdiscitur, Facillima lēctiō facillimē ēdiscitur.

Multi hominēs multum valent, Plūrēs hominēs plūs valent, Plūrimī hominēs plūrimum valent.

Magnus homō magnopere labōrat,

Maior homō magis labōrat, Maximus homō maximē labōrat.

Parvus puer (paulum) labörat, Minor puer minus labōrat, Minimus puer minimē labōrat.

Aliam trīstissimam fābulam nunc auciìtis. Antīquissima est fābula, nec prīmum ā vōbīs audītur (dīcō hanc fābulam et antehāc ā multīs hominibus auditam esse et nunc iterum ā vōbīs audīrī).

5 Anus veterrima et pauperrima canem veterrimum et fidēlissimum habet (dīcō hoc animal vetus et fidēle ab anū antīquā et paupere possidērī). Ab hōc animālī vetere et fidēlī maximē amātur fēmina vetus (dīcō fēminam amārī), ab hāe anū dīligentissimē cūrātur canis. 10 - Canis igitur ēsurit, et cibus eī ex armāriō ab anū petitur (dīcō cibum petī, et saepe antehāe petītum esse). Quae ā canibus libentissimē eduntur? Libenter editur carō, placentae libentius fortasse, sed libentissimē ossa (dīcō carnem placentās ossa ab animālibus 
canīnīs, et ossibus exceptīs ab hominibus quoque edī, 15 hominibusque idōnea esse).

Sīc os $\bar{a}$ fēminā petitur. Saepe antehāc armārium apertum esse et ossa petita et reperta esse putō, sed hodiē armārium vacuum esse invēnit anus. Tum lacrimāvit, et canis in diēs iēiūnior factus est. Nōnne 20 crēditis anum quoque iēiūnam factam esse? Sed paucōs post diēs animal illud fidēle vītã excessit, - famẽ mortuum est. Putō fēminam illam miserrimam morī velle, sed nōn moritur. Lentē surgit, lentius ad canem suum it, lentissimē oculōs canis claudit. Hunc fidēliter 25 amāvit, fidēlius cūrāvit, fidēlissimē sepelīvit.

Hinc illae lacrimae!

\section{PẼNSUM XXX}

Iterum fābula dē anū ā mē vōbīs nārrātur, sed hanc fēminam vōbīs nōndum latīnīs litterīs nōtam esse putō. Haec fēmina veterrima in calceō vīxisse dīcitur (calceum tālī reī minimē idōneum eam incoluisse audiō). Multōs fīliōs, plūrēs fîliās habuit; hī omnēs 5 līberī magnum strepitum magnumque clāmōrem fēcērunt; sed peiōrēs līberī maiōrēs clāmōrēs, pessimī maximōs sustulērunt. Puerī puellaeque multum $\bar{a}$ mātre suā amātī sunt, sed silentium plūs ab eā amātum est. Itaque prīmum parvus puer.ad mātrem vocā- 10 tus est; iūs illī datum est, sed pānis nōn datus est. Magnā vōce conclāmāvit, et anus iterum illum ad sē vocãvit, et palmā suā eī gravem plāgam īnflīxit. Inde ad lectulum celeriter missus est. Deinde minor puella ā mātre appellāta est, iūs huic quoque sed nōn pānis 15 
datus est (dīcō minōrem puellam appellātam esse, iūs datum esse, pānem nōn datum esse). Haec maiōre vōce conclāmāvit; ad mātrem vocāta est, ā mātre percussa est, celerius ad lectulum missa est. Et omnibus 20 lỉberīs idem datur: prīmum iūs, et posteā plāgae; prīmīs multum iūris et paulum plāgārum; ultimīs minus iūris, et plūs plāgārum. Celeriter eunt prīmī ad lectulōs, celerrimē eunt ultimī.

Poēma quod īnfrā scrīptum est facillimē, ut opīnor, 25 intellegētis.

Anxia vīxit anus, soleā conclūsa minūtā,

Pressaque tot puerīs et nescia quid sit agendum.

Iūs illīs tepidum quae cum sine pāne parāsset, Saeva flagellāvit cunctōs, cubitumque remīsit.

\section{PẼNSUM XXXI}

Fōrmulam Prīmam vel Fōrmulam Secundam in Tempore Praesentī (Pēnsum I, Pēnsum II) et in Tempore Praeteritō (Pēnsum XIV) expressam iam habuimus. Fōrmulās in Tempore Futūrō expressās hīc habēmus.

I. Vōx Actīva. (Heri mappam percussĩ: hodiē mappam feriō.) Crās mappam feriam.

Quaestiō est: Quid faciēs? Quid faciam? Quid faciet? et c.

$\begin{array}{llll}\text { Crās } & \text { feriam, } & \text { feriēs, } & \text { feriet. } \\ \text { Crās } & \text { feriēmus, } & \text { feriētis, } & \text { ferient. } \\ \text { Crās } & \text { induam, } & \text { induēs, } & \text { induet. } \\ \text { Crās } & \text { induēmus, } & \text { induētis, } & \text { induent. }\end{array}$




$\begin{array}{llll}\text { Crās } & \text { rapiam, } & \text { rapiēs, } & \text { rapiet. } \\ \text { Crās } & \text { rapiēmus, } & \text { rapiētis, } & \text { rapient. } \\ \text { Crās } & \text { spectābō, } & \text { spectābis, } & \text { spectābit. } \\ \text { Crās } & \text { spectābimus, } & \text { spectābitis, } & \text { spectābunt. } \\ \text { Crās } & \text { torquēbō, } & \text { torquēbis, } & \text { torquēbit. } \\ \text { Crās } & \text { torquēbimus, } & \text { torquēbitis, } & \text { torquēbunt. }\end{array}$

Crās mappam feriam.

Dīcō mẽ crās mappam percussūrum esse.

Crās mappam induet.

Dìcō eum (eam) crās mappam indūtūrum (indūtūram) esse.

Crās puella cucullum rapiet. Dīcō puellam crās cucullum raptūram esse.

Crās effigiem spectābitis.

Dìcō vōs crās effigiem spectātūrōs esse.

Crās animālia mappās torquē- Dīcō animālia crās mappās torbunt. türa esse.

II. Vōx Passĩva. In Pēnsō XXVIII Tempus Praesēns et Tempus Praeteritum habuistis. (Heri mappa percussa est: hodiē mappa ferītur.) Crās mappa feriètur.

\section{Quaestiō est: Quid fiet?}

Crās mappa feriētur.

Crās cucullus induētur.

Crās os rapiētur.

Crās liber spectābitur.

Crās auris torquēbitur.

Crās mappa feriētur.

Crās cucullus induētur.

Crās os rapiētur.

Crās librī spectābuntur.

Crăs meae aurēs torquēbuntur.
Crās mappae ferientur. Crās cucullī induentur. Crās ossa rapientur. Crās librī spectābuntur.

Crās aurēs torquēbuntur.

Dīcō mappam crās percussum irī.

Dīcō cucullum crās indūtum īrī. Dìcō os crās raptum īī. Dīcō librōs crās spectātum īiñ. Dīcō meās aurēs crās tortum îrī. 
Verba Dēpōnentia fōrmās plērumque passīvās, significātiōnēs actīvās habent.

Partēs Prīncipālēs, exemplī grātiā, sunt: Sequor: sequī: secūtus sum.

Hodiē sequor . . . . . . Dīcō mē hodiē sequī.

Heri secūtus sum . . . . . . Dīcō mē heri secūtum esse.

Crās sequentur . . . . . Dīcō eōs crās secūtūrōs esse.

Imperātīvus: (Tū) sequere. (Vōs) sequiminī.

Partēs Prīncipālēs: Sum: esse: fuĩ: futūrus.

Tempus Futūrum: Erō. Eris. Erit. Erimus. Eritis. Erunt.

Partēs Prīncipālēs: Possum: posse: potūi, (Īnfīnitīivum Futūrum dēest)

Tempus Futūrum: Poterō.

Poteris.

Poterit.

Poterimus.

Poteritis.

Poterunt.

\section{PĒNSUM XXXII}

Dēbita reddere melius est quam negāre. Āiunt quondam in urbe Germānōrum permultōs mūrēs habitāvisse. Magistrātūs voluērunt haec animālia expellere, sed mūrēs manēre māluērunt. "Fēlēs im5 portābimus," dīxērunt cīvēs; sed fēlēs hī mūrēs nōn timuērunt. "Omnia dēlēbunt," dīxērunt cīvēs; et vērō paene omnia dēlēvērunt. Tum, post longum tempus, ad magistrātūs vēnit tībīcen senex. "Ego expellam vōbīs hōs mūrēs," dīxit hic homō procērus 10 et macer: "sed quid mihi dabitis?" Tum magistrātūs dīxērunt sē tībīcinī m nummōs datūrōs esse.

Āiunt in mediā urbe stetisse tībīcinem, et tībīis canere coepisse; statim ex omnibus partibus urbis vēnisse mūrēs. "Ad flūmen maximum mē vertam," 

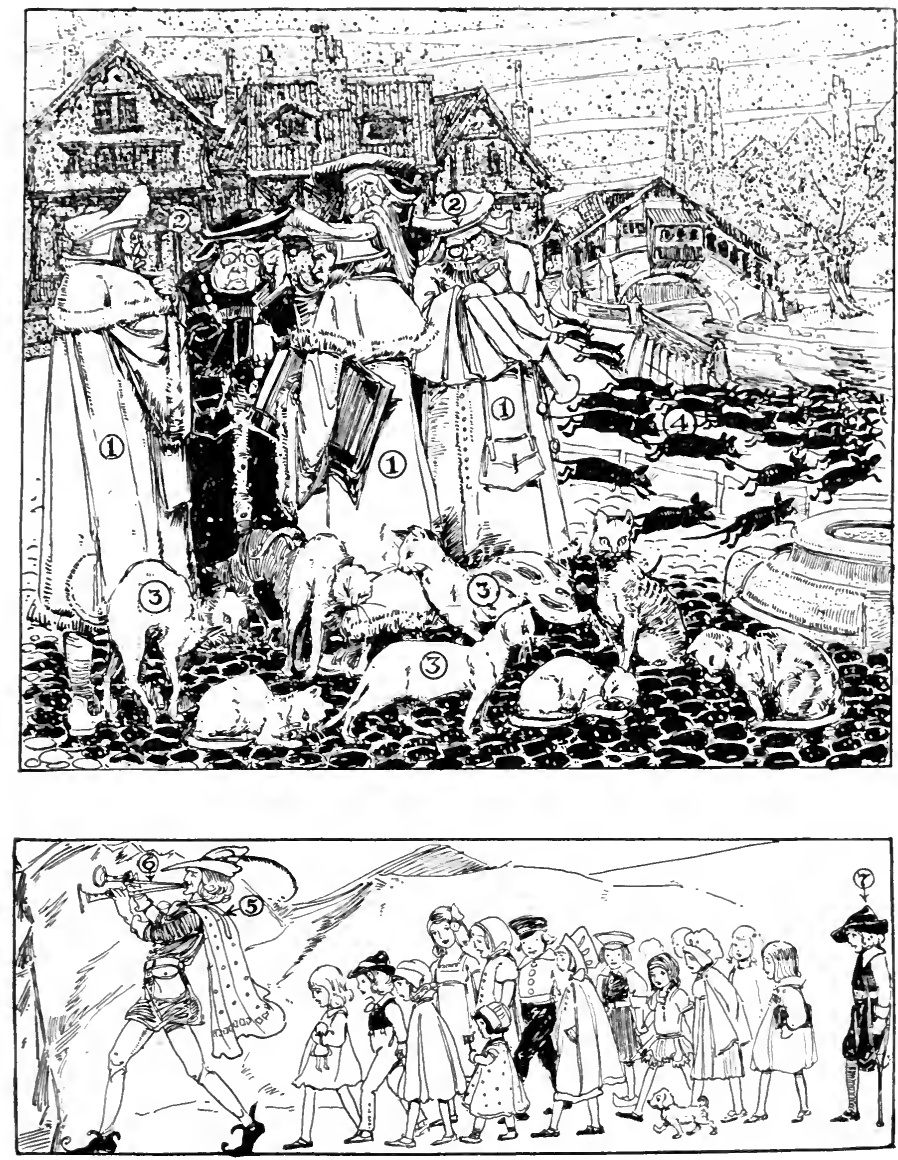

\section{Magistrātūs Mūrềs Tībīcen}

1. magistrātūs. 2. cōgitant. 3. fēlēs. 4. mūrēs. 5. tībīecn macer. 6. tîbiīs canit. 7. puer pede claudus. 
. 
dīxit tībīcen; et omnēs mūrēs secūtī sunt; mōmentō 15 temporis ōmnēs in flūmine dēmersī sunt et periērunt. Mox revertit ille ad magistrātūs, quod praemiō potīrī voluit, et dīxit, "Date mihi nummōs meōs." Sed magistrātūs sēcum cogitāvērunt: "Mūrēs iam occìdit, nōn poterit illīs vītam reddere; hominem dīmittēmus." 20 Itaque mīsērunt nūntium, et iussērunt hunc dīcere: "Iocus fuit; ūnum nummum tibī habēbis."

Quid ergō faciet tībīcen? Attendite. Tìbiās iterum statim capiet, et canet. Et nunc convenient omnēs puerī et puellae, et tībīcinem sequentur. Nec patrēs 25 nec mātrēs nec magistrātūs eōs retinēre poterunt. Hoc quoque putō: tībīcinem mox ad montem magnum adductūrum esse līberōs; illum in montis latere iānuam apertūrum esse, et omnēs initūrōs esse. Ūnum puerum āiunt claudum pede fuisse, et nimis lentē 30 prōcessisse; sīc relictus est. Certō sciō hōs parentēs numquam posteā vīdisse lỉberōs; doluisse; sed eōs recipere nōn potuisse.

Nōnne putātis melius esse dēbita reddere quam negāre?

\section{PĒNSUM XXXIII}

Duo nova tempora hōc in pēnsō discimus, quōrum nōmina sunt Plūsquamperfectum et Futūrum Perfectum. Īnfrā et fōrmās et ūsūs inspicite, ut omnia plānē intellegātis.

I. Nudiūs tertius mappam torsī.

Heri dīxī mē mappam iam prīdiè torsisse. Itaque, heri mappam nōn torsī, sed torseram. 
A. Tempus Plūsquamperfectum. Vōx Actĩva.

Quaestiō: Quid fēcerās? et c.

$\begin{array}{lll}\begin{array}{l}\text { Torseram, } \\ \text { Torserāmus, }\end{array} & \begin{array}{l}\text { torserās, } \\ \text { torserātis, }\end{array} & \begin{array}{l}\text { torserat. } \\ \text { torserant. }\end{array} \\ \begin{array}{l}\text { Indueram, } \\ \text { Induerāmus, }\end{array} & \begin{array}{l}\text { induerās, } \\ \text { induerātis, }\end{array} & \begin{array}{l}\text { induerat. } \\ \text { induerant. }\end{array} \\ \begin{array}{c}\text { Percusseram, } \\ \text { et c. }\end{array} & \text { percusserās, } & \text { percusserat; } \\ \text { Mappam torseram; dīcō mē mappam torsisse. }\end{array}$

B. Tempus Plūsquamperfectum. Võx Passĩva. Quaestiō: Quid factum erat?

Mappa (ã mē, ā tē, ã nōbīs, et c.) torta erat.

Mappa indūta erat, mappa percussa erat, mappae percussae erant.

Mappa indūta erat; dīcō mappam indūtam esse.

II. Hodiē dīcō mē mappam torquēre. Crās dīcam mē mappam iam torsisse. Itaque, crās mappam nōn torquēbō, sed torserō.

A. Tempus Futūrum Perfectum. Vōx Actĩva. Quaestiō: Quid fēceris? et c.

$\begin{array}{lll}\text { Torserō, } & \text { torseris, } & \text { torserit. } \\ \text { Torserimus, } & \text { torseritis, } & \text { torserint. } \\ \text { Induerō, } & \text { indueris, } & \text { induerit. } \\ \text { Induerimus, } & \text { indueritis, } & \text { induerint. } \\ \begin{array}{c}\text { Percusserō, } \\ \text { et c. }\end{array} & \text { percusseris, } & \text { percusserit; }\end{array}$

Mappam torserō; dīcō mē mappam tortūrum esse. 
B. Tempus Futūrum Perfectum. Vōx Passīna. Quaestiō: Quid factum erit?

Mappa (ā mè, ã tē, ā nōbīs, et c.) torta erit.

Mappa indūta erit, mappa percussa erit, mappae percussae erunt. Mappae percussae erunt; dĩcō mappās percussum ìrī.

\section{PĒNSUM XXXIV}

Vēnātor, quī tōtum diem per silvās vagātus erat, ad tumulum accessit quem anteā nōn vīderat. Summās frondēs (quās avēs congesserant) āmōvit; sub quibus puerum puellamque invēnit quī diū ibi dormīverant. Quōrum dē fātō (nam mortū̄ erant) haec est fābula. 5

Voluerant flōrēs carpere; quōs pulcherrimōs intrā silvās abditōs esse arbitrātī erant. Quās in silvās igitur errāverant, sed nōn satis magnum numerum colligere potuerant. Iam multa mīlia passuum iverant, quae circiter $\mathrm{xx}$ esse putāvērunt, et advēnerant tenebrae 10 noctis. Quae timōre puellam opprimere coeperant, sed frāter fortis erat, et nōndum lacrima ex oculīs illī ēlapsa erat. Nōn diū dubitāverat, sed sorōrī dixerat: "Viam reperīe nōn possumus per quam ad hunc locum pervēnimus; haec arbor sub quā stāmus 15 nōs per noctem dēfendet. Est bona arbor, cuius glandēs nōbīs cibum dabunt, et quae ipsa nōbīs praesidiō erit à tempestāte; cui quoque māne grātiās agēmus. Crās bene dormīverō, et tū bene dormīveris; sìc validiōrēs erimus." Quō dictō, lassitūdine cōnfectī sub 20 arbore cōnstiterant, Deum adōrāverant, ut ā parentibus doctī erant, mox dormīverant.

Māne êvigilāverant lỉberī, et rēctā domum īre cōn- 
stituerant. Sed omnia indicia quae anteā nōtāre cōn25 suēverant nunc falsa erant-arborēs quārum rāmī longiōrēs fuerant, cōnsilium agricolae ā quō dē viā quaesīverant. Dixxerant, "Sub vesperum domum pervēnerimus; domō nōn longē absumus; domī parentēs nōs colent, quibus tam dī̄ adventus noster exspectā30 tus erit." Sed nōn pervēnerant. Nōn omnia nārrābō quae fēcērunt; hoc ad fīnem factum esse sciō, quod suprā nārrāvī.

$\begin{array}{llllll}\text { Quĩ } & \text { quae } & \text { quod } & \text { Qū̃ } & \text { quae } & \text { quae } \\ \text { Quem } & \text { quam } & \text { quod } & \text { Quōs } & \text { quās } & \text { quae } \\ \text { Cuius } & \text { cuius } & \text { cuius } & \text { Quōrum } & \text { quārum } & \text { quōrum } \\ \text { Cui } & \text { cui } & \text { cui } & \text { Quibus } & \text { quibus } & \text { quibus } \\ \text { Quõ } & \text { quã } & \text { quõ } & \text { Quibus } & \text { quibus } & \text { quibus }\end{array}$

\section{PẼNSUM XXXV}

Ūnum tempus verbī adhūc restat quod vōbīs nōndum dedimus. Sì dīcō "torsī" significō mē semel antehāe torsisse: quodsī dīcere volō mē saepe vel diū vel cōnsuētūdine aliquid antehāc torsisse (vel cōnātum esse, vel coepisse - quae significātiōnēs rāriōrēs sunt) tum dĩcō torquēbam. Hanc partem verbī Tempus Imperfectum appellāmus; nōnnumquam quidem idem ferē significat quod Tempore Praeteritō quoque significātur.

A. Vōx Actīva.

Quaestiō est: Quid faciēbãs? et c.

$\begin{array}{llll}\text { Mappam } & \text { feriēbam, } & \text { feriēbãs, } & \text { feriēbat, } \\ \text { mappam } & \text { feriēbāmus, } & \text { feriēbātis, } & \text { feriēbant. } \\ \text { Mappam } & \text { induēbam, } & \text { induēbās, } & \text { induēbat, } \\ \text { mappam } & \text { induēbāmus, } & \text { induẽbātis, } & \text { induëbant. }\end{array}$




\begin{tabular}{|c|c|c|c|}
\hline $\begin{array}{l}\text { Mappam } \\
\text { mappam }\end{array}$ & $\begin{array}{l}\text { rapiēbam, } \\
\text { rapiēbãmus, }\end{array}$ & $\begin{array}{l}\text { rapiēbās, } \\
\text { rapiēbātis, }\end{array}$ & $\begin{array}{l}\text { rapiēbat, } \\
\text { rapiēbant. }\end{array}$ \\
\hline $\begin{array}{l}\text { Mappam } \\
\text { mappam }\end{array}$ & $\begin{array}{l}\text { spectābam, } \\
\text { spectābāmus, }\end{array}$ & $\begin{array}{l}\text { spectābās, } \\
\text { spectābātis, }\end{array}$ & $\begin{array}{l}\text { spectābat, } \\
\text { spectābant. }\end{array}$ \\
\hline $\begin{array}{l}\text { Mappam } \\
\text { mappam }\end{array}$ & $\begin{array}{l}\text { torquēbam, } \\
\text { torquēbāmus, }\end{array}$ & $\begin{array}{l}\text { torquēbās, } \\
\text { torquēbātis, }\end{array}$ & $\begin{array}{l}\text { torquēbat, } \\
\text { torquēbant. }\end{array}$ \\
\hline $\begin{array}{l}\text { Eram, } \\
\text { Poteram, }\end{array}$ & $\begin{array}{l}\text { is, erat, } \\
\text { terās, poterat, }\end{array}$ & $\begin{array}{l}\text { mus, erā } \\
\text { erāmus, pote }\end{array}$ & $\begin{array}{l}\text { is, erant. } \\
\text { ràtis, poterant }\end{array}$ \\
\hline $\begin{array}{l}\text { Mappam } \\
\text { Mappam } \\
\text { n lūdō e }\end{array}$ & $\begin{array}{l}\text { èbam; dícō m } \\
\text { quēbam; dícō } \\
\text { s; dícō vōs in } \\
\text { oterant; dìcō }\end{array}$ & ga & se. \\
\hline
\end{tabular}

B. Vōx Passīva.

Quaestiō est: Quid fiēbat? et c.

Mappa feriēbātur; mappae feriēbantur.

Mappa induēbātur; mappae induēbantur; et c.

Mappa induēbātur; dícō mappam indūtam esse.

\section{PĒNSUM XXXVI}

Fābulam pernōtam saepe audīvistis dē Washingtoniō et cerasō. Hanc fābulam nārrābō, et fortasse nōnnūlla addam quae antehāc nōn audīvistis. Georgius cerasōs amābat (semper amāvit), et pater eius multās cerasōs in agrō suō habuit. Sāturnī diē, quo- 5 niam ad lūdum nōn ībat (cōnsuētūdine nōn iit), prīmā lūce surrēxit, et in agrum properāvit. Ientāculum nōndum habuerat, itaque mox ēsuriēbat (ēsurīre coepit). Multās cerasōs rubrās et dulcēs vīdit, et tangere cōnābātur (iterum iterumque cōnātus est); 10 sed tangere nōn potuit. Mox arborem ascendēbat (ascendere cōnātus est); sed nimis parvus fuit, neque 
īmōs rāmōs attingere potuit. Et semper ēsuriēbat (maior ūnō quōque mōmentō factus est famēs); et 15 oblīiñscēbātur (oblīvisscì coepit) patrem sē iussisse secūrim numquam tangere; post longam hōram nōn iam sē continēbat (continēre cōnātus est), sed ad domicilium revertit et secūrim petīvit.

Tum, ut verbō dīcam, arborem cecīdit; et cerasōs 20 gustābat (gustāre coepit); sed hōc ipsō tempore advēnit pater eius, et puer fugiēbat (fugere voluit). Sed pater "Manē" inquit: "aliquid ā tē quaerere volō." Georgius lacrimābat (lacrimāre coepit), sed pater illī virgam exhibuit, et quaesīvit, "Quis arborem cecīdit? 25 Sĩ negābis tē fēcisse, tibi crēdam." Et Georgius virgam spectābat (diū spectāvit) et cōgitābat (diū cōgitāvit). Pater enim sevērus fuit, et magnā sevēritāte pūniēbat (semper pūnīvit). Fìlius quoque scīvit patrem hōc tempore sibi nōn ignōtūrum esse. Sed fortis 30 erat (semper fuit) et vērāx, et dīxit: "Ego, pater, cecīdī. Mentīīi nōn possum."

\section{PĒNSUM XXXVII}

In hōc pēnsō Cōnspectum Verbōrum cum quaestiōnibus habētis.

I. Vōx Actīva.

Partēs Prīncipālēs $\left\{\begin{array}{l}\text { Faciō: facere: fēcī: factum. } \\ \text { Tollō: tollere: sustulī: sublātum. }\end{array}\right.$

A. Tempus Plüsquamperfectum.

Quid iam antehăc fēcerātis?

Quid dīcitis (vōs iam antehāe

fēcisse)?
Iam antehāc sustulerāmus.

Dỉcimus nōs iam antehāc sustulisse. 


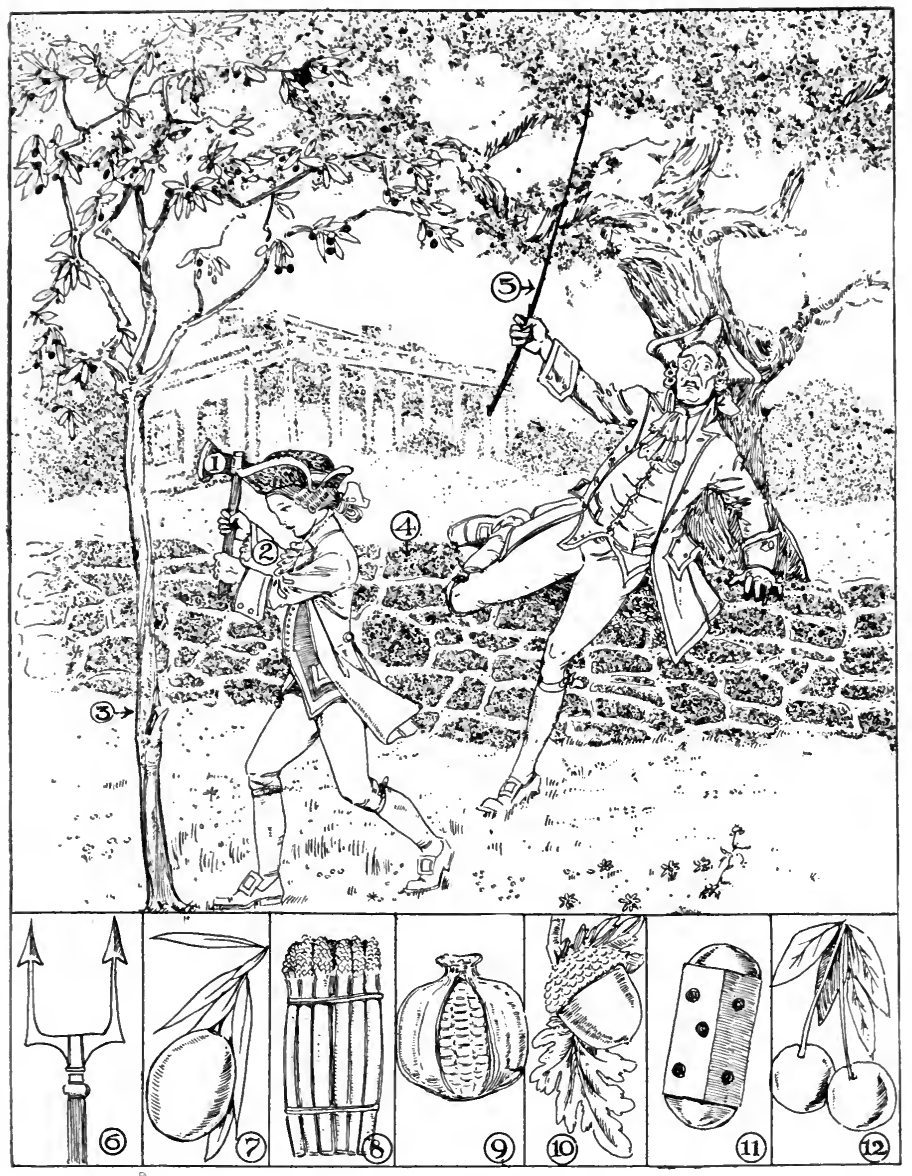

\section{Geōrgius Cerasus}

1. secūris. 2. dēcīdit. 3. cerasus. 4. mūrus. 5. virga. 6. bidēns. 7. olīva. 8. asparagus. 9. mālum Pūnicum. 10. glāns. 11. ālea. 12. cerasi. 
B. Tempus Practeritum.

Quid antehāc fẽcistis? . . . Antehāc sustulimus.

Quid dỉcitis (vōs antehāe fē-

cisse)? . . . . . . . Dīcimus nōs antehāc sustulisse.

C. Tempus Imperfectum.

Quid cōnsuētūdine faciēbātis? . Cōnsuētūdine tollēbāmus.

Quid dīcitis (vōs cōnsuētūdine

fēcisse) . . . . . . . . Dīcimus nōs cōnsuētūdine sustulisse.

D. Tempus Praesēns.

Quid nunc facitis? . . . . . Nunc tollimus.

Quid dīcitis (vōs nunc facere)? . Dìcimus nōs nunc tollere.

E. Tempus Futürum.

Quid posthāc faciētis? . . . . Posthāc tollēmus.

Quid dīcitis (vōs posthāc fac-

tūrōs esse)? . . . . . . Dīcimus nōs posthāc sublātūrōs esse.

F. Tempus Futūrum Perfectum.

Quid post trēs diēs iam fēce-

ritis? . . .... Post trēs diēs iam sustulerimus.

Quid dīcitis (vōs post trēs diēs iam factūrōs esse)? . . . . Dỉcimus nōs post trēs diēs iam sublātūrōs esse.

\section{Vōx Passĩva.}

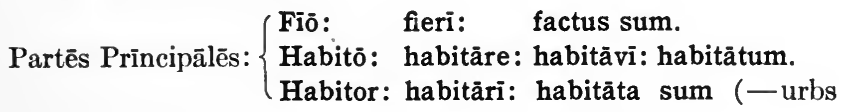
loquitur).

A. Tempus Plūsquamperfectum.

Quid iam antehāc factum erat? . Urbs iam antehāc habitāta erat. Quid dỉcitis (iam antehāc factum esse)?..... Dịcimus urbem iam antehāc habitātam esse. 
B. Tempus Praeteritum.

Quid antehāc factum est? . . Urbs antehāc habitāta est.

Quid dīcitis (antehāe factum

esse)?... . . . . Dìcimus urbem antehāc habitātam esse.

C. Tempus Imperfectum.

Quid cōnsuētūdine fiēbat? . . Urbs cōnsuētūdine habitābātur.

Quid dīcitis (cōnsuētūdine fac-

tum esse)? . . . . Dīcimus urbem cōnsuētūdine habitātam esse.

D. Tempus Praesēns.

Quid nunc fit? . . . . . . Urbs nunc habitātur.

Quid dīcitis (nunc fierī)? . . Dīcimus urbem nunc habitārī.

E. Tempus Futūrum.

Quid posthāc fiet? . . . . Urbs posthāc habitābitur.

Quid dīcitis (posthāe factum

irī)? . . . . . . . Dỉcimus urbem posthāc habitātum ìrì.

F. Tempus Futūrum Perfectum.

Quid iam posthāc factum erit? Urbs iam posthāc habitāta erit. Quid dīcitis (iam posthāe fac-

tum ỉīi)? . . . . . . Dīcimus urbem iam posthăc habitātum ìrī.

\section{PĒNSUM XXXVIII}

Prīmum in Pēnsō XXVIII verbum duābus partibus cōnfectum vidētis; exemplī grātiā, Mappa spectāta est. Haec prīma pars verbī Participium appellātur. Verba plērumque habent participia quattuor. Hōc modō eīs ūtimur: 
Spectātus: spectāta: spectātum (- haec iam intellegitis).

Spectātūrus: spectātūrus sum idem ferē significat ac spectābō.

Spectāns: Puer effigiem spectāns eam ferit, id est, Puer effigiem spectat et eam ferit.

Spectandus: spectandus sum significat: Necesse est mē spectảrì.

Veniendum: veniendum est vōbis significat: Necesse est vōs venire.

Īnfrā scrīpta sunt Participia:

$$
\begin{array}{clcc}
\text { Pass. } & \text { Act. } & \text { Act. } & \text { Pass. Futr. } \\
\text { Praet. } & \text { Fut. } & \text { Praes. } & \text { (Gerundivum) }
\end{array}
$$

Feriō: Percussus Percussūrus Feriēns Feriendus

Induō: Indūtus Indūtūrus Induēns Induendus

Rapiō: Raptus Raptūrus Rapiēns Rapiendus

Spectō: Spectātus Spectātūrus Spectāns Spectandus

Torqueō: Tortus Tortürus Torquēns Torquendus

Haec verba summā cūrā înspicite, saepe enim vōbīs ūsūrpanda erunt:

(Ego) volō, (tū) vīs, (ille) volt;

(Nōs) volumus, (vōs) voltis, (illī) volunt.

Volēbam, et c. (simile est verbō "induere").

Eōdem modō: Nōlō, nōn vīs, nōn volt; Nōlumus, nōn voltis, nōlunt. Nōlēbam, et e.

Et hoc quoque: Mālō, māvis, māvolt;

Mãlumus, mãvoltis, mālunt.

Mālēbam, et $\mathrm{e}$.

Hōrum verbōrum partēs prīncipālēs hae sunt:

Volō: velle: voluī. Nōlō: nōlle: nōluī. Mālō: mālle: mãlui. 


\section{PẼNSUM XXXIX}

Quondam in Graeciā habitāvit puer, cui nōmen fuit Phacthōn. Hic mātrem amantem habuit, et pater, fīliō nōn cognitus (tantum cognātus) fuit Apollō. Māter Phaethontĩ quaerentī multa nārrābat dē patre 5 cius, splendentī deō sōlis. Itaque puer multum sē iactābat, dīcēns amīcīs suīs sē esse fīlium sōlis. Paulō post, amīcī hunc glōriantem ōderant, et dīxērunt illī dēmōnstrandum esse Apollinem esse patrem. Respondit sē hoc factūrum esse. Fīliō quaerentī (et querentī) 10 māter dīxit: "Versātur māne in regiōne sōlis orientis pater tuus; eō eundum est et petendum. Ego comes īre nōn possum; sed ille sciet tē esse suum ipsīus fĩlium."

Itaque puer in eam partem prōcessit. Mox nōn impedītus ad patrem pervēnit, et omnia illī nārrāvit.

15. Furōre incēnsus propter contumēliam puerōrum Apollō dīxit sē quodcumque rogāret fīliō datūrum esse. Fīlius ignōrāns dīxit sē velle equōs sōlis illō ipsō diē per caelum agere. Cui pater, "Hoc tibi minimē est petendum," inquit, "equī tibi nōn sunt pāritūrī." Sed 20 diū recūsāns postrēmō permīsit hoc fīliō quod iūrāverat. Itaque Phaethōn in currum ascendit, Aurōra ab Apolline iussa forēs aperuit, et equī à rēge appellātī in caelum exiērunt.

Duās hōrās nihil timēns puer bene agēbat, sed equī 25 scientēs sē nōn ab Apolline regī, tandem ab itinere discessērunt, et propius terram contendēbant. Arborēs viridēs, rīvōs fluentēs, agrōs virentēs, incendēbant; omnēs quoque in Āfricā habitantēs nigrī factī sunt, et ad hunc diem nigrī manent. Exinde longē à terrā 
discessērunt equī perterritī, et omnia frīgēbant. Mag- 30 nīs clāmōribus rogābant Iovem patientēs mortālēs, dīcentēs sē moritūrōs esse. Et Iuppiter è somnō ēvigilāns mīsit fulmen, et Phaethōn statim è caelō dēiectus, mortuus et ignĩ cremātus, in flūmen concidit, et ad hoc tempus ā Cycnō amīcō in aquā petitur.

\section{PẼNSUM XL}

Commemorant scrīptōrēs in Siciliā insulā fuisse puellam, Proserpinam appellātam. Cum aliīs puellīs parī aetāte cottīdiē ad collēs exībat. Quōdam diē mediae aestātis complūrēs hārum puellārum colloquēbantur; altera pars prope flūmen in aequō locō gradūs cōnferre volēbat, aliae mare cōnspiciendī causā collem ascendere māluērunt. Proserpina sē cum illīs coniūnxerat quae collem dēlēgerant, nam neque altitūdō neque difficultās iter cōnservandī illan impedīvit. Celeritāte omnēs illī cessērunt, auctōritās illīus ab 10 omnibus accepta est, cupidē cōnfertō agmine illam cōnsequēbantur.

Nōn longē ab alterā parte aberant, atque cēterae puellae flōrēs iam carpēbant. Proserpina autem dux adhūc nōlēbat sinum flōribus complēre; prīmum quās- 15 dam herbās carpere voluit, quod anum aegram cognōverat, cui cōpiam cottīdiānam frūctuum et herbārum cum dìligentiā adferēbat. Herbae in corbem amplum coniectae erant, quem dextrā manū sēcum portāre coacta est; deinde aliās animum advertit, et mox suae 20 cohortī aderat. Hae frūctūs et bācās iam comparāverant, et prandium commūne collocāverant. 
Post satis longum tempus edere dēstitērunt et domum gradūs referendī cōnsilium cēpērunt. Iam 25 dēcrētum erat voluntātī Proserpinae concēdere, sed subitō, "Sonitum audiō," monet puella prope Proserpinam sedēns, "aliquis adest." Colloquiō omnēs dēsistunt, neque timōre affectae sē commovēre audent. Quod nōlunt, vident; nam ex propinquō locō adoritur 30 deus terribilis, bidente armātus, et certō sciunt illum Plūtōnem esse. Statim cōnfirmat sē Proserpinam nōlentem volentem ad sua rēgna dēlātūrum esse, et rapit. Magnā vōce clāmant puellae, sed auxilium adferre nōn possunt, et cum captīiā pulcherrimā abit 35 deus.

\section{PĒNSUM XLI}

Modum novum habēmus, neque Indicātīvum neque Īnfīnītīvum, sed Subiūnctīvum. Illūstrātur in hāc

\section{Fōrmulā Quīntā:}

\begin{tabular}{|c|c|c|c|}
\hline $\begin{array}{l}\text { Quaerō } \\
\text { Animadvertōo } \\
\text { Exquīrō } \\
\text { Rogō }\end{array}$ & $\begin{array}{l}\text { quis } \\
\text { cuius } \\
\text { cui } \\
\text { quem }\end{array}$ & $\begin{array}{l}\text { mē } \\
\text { cucullum } \\
\text { nummum }\end{array}$ & $\begin{array}{l}\frac{\text { feriat. }}{\text { induat. }} \\
\text { rapiat. } \\
\text { spectet. }\end{array}$ \\
\hline Ostendō & quō & mappa & torqueātur. \\
\hline
\end{tabular}

Tempus Praeseñs Modī Subiūnctĩvĩ:

\begin{tabular}{|c|c|c|}
\hline $\begin{array}{l}\text { Feriam, } \\
\text { Feriāmus, } \\
\text { Feriātur, }\end{array}$ & $\begin{array}{l}\text { feriās, } \\
\text { feriātis, } \\
\text { feriantur. }\end{array}$ & $\begin{array}{l}\text { feriat. } \\
\text { feriant. }\end{array}$ \\
\hline $\begin{array}{l}\text { Induam, } \\
\text { Induāmus, } \\
\text { Induātur, }\end{array}$ & $\begin{array}{l}\text { induās, } \\
\text { induātis, } \\
\text { induantur. }\end{array}$ & $\begin{array}{l}\text { induat. } \\
\text { induant. }\end{array}$ \\
\hline
\end{tabular}




\begin{tabular}{|c|c|c|}
\hline $\begin{array}{l}\text { Rapiam, } \\
\text { Rapiāmus, } \\
\text { Rapiātur, }\end{array}$ & $\begin{array}{l}\text { rapiās, } \\
\text { rapiātis, } \\
\text { rapiantur. }\end{array}$ & $\begin{array}{l}\text { rapiat. } \\
\text { rapiant. }\end{array}$ \\
\hline $\begin{array}{l}\text { Spectem, } \\
\text { Spectēmus, } \\
\text { Spectētur, }\end{array}$ & $\begin{array}{l}\text { spectēs, } \\
\text { spectētis, } \\
\text { spectentur. }\end{array}$ & $\begin{array}{l}\text { spectet. } \\
\text { spectent. }\end{array}$ \\
\hline $\begin{array}{l}\text { Torqueam, } \\
\text { Torqueāmus, } \\
\text { Torqueātur, }\end{array}$ & $\begin{array}{l}\text { torqueās, } \\
\text { torqueātis, } \\
\text { torqueantur. }\end{array}$ & $\begin{array}{l}\text { torqueat. } \\
\text { torqueant }\end{array}$ \\
\hline
\end{tabular}

Haec quoque animadvertite:

Velim, velis, velit, velimus, velitis, velint.

Nōlim, et c. Mālim, et c.

Sim, sis, sit, simus, sitis, sint.

Eam, eās, eat, eāmus, eātis, eant.

Possim, possis, possit, possimus, possitis, possint.

\section{PĒNSUM XLII}

Animadvertunt puellae quālēs equĩ currum trahant, et quam in partem deus ferātur; sed nē haec quidem Cererī mātrī indicāvisse videntur. Vespere Proserpina domum nōn revertitur, itaque māter exīstimat aliquid malī certē illī accidisse. Itaque ēgreditur, magis et 5 magis calamitātem verēns. Per tōtam noctem mulier misera errātiōnem nōn intermittit, vix crēdēns tantum facinus susceptum esse quantum frāter fēcerat. (Nam Cerēs soror Plūtōnis fuisse dīcitur.)

Interim Plūtō ēreptam virginem cohortātur ad amī- 10 citiam, sī nōn ad amōrem; modo pollicētur, modo minātur; illa libertātem tantum dēsīderat, neque lïberātur. Tandem in fugā ad rīvum prōgressī sunt, quĩ 
inimīcus illīs sē obicit velut mūrum. Plūtō nōn pos-

15 tulat cūr sē obiciat, sed certō ictū terram ferit, ibique fit magnus hiātus. Certō sciēns quō eant, Proserpina zōnam suam in rīvum iacit. Prōgrediuntur, et mox in rēgnum Plūtōnis intrant.

Sed quid putātis intereā facere Cererem? Diū va20 gātur, sed nēmō docēre potest ubi sit fīlia. Et iam spēs ferē dēest; ambulat casū prope rīvum in İtaliā, et subitō, mīrābile dictū, - zōnam videt. Statim fīliae esse cognōscit, et capit. Prōgreditur, et mox ad fontem venit, cui nōmen est Arethūsa. Dormit Cerēs, 25 et fōns loquitur. Hic fōns - paene incrēdibile est subter terram dēscendit, rēgna Plūtōnis praeterit, paulō post in Siciliā exit. Ille memoriā tenet, sē Proserpinam vīdisse, itemque mātrem certiōrem facit ubi sit. Dolet Cerēs, quod cēnset Proserpinam numquam līberam 30 ēgressūram esse. Dolet multitūdō gentium, quod Cerēs cōnstituit terram frūctibus nōn diūtius iuvāre, et hiems ācris omnēs herbās interficit.

\section{PĒNSUM XLIII}

I. Sì tē ad amīcum meum mittō (vel mīsī), proptereā quod volō (vel voluī) tē eĩ aliquid dīcere;

(a) Mittō tē ut hoc dícās; vel

(b) Mìsī tē ut hoc dìcerēs.

II. Quodsī tē retineō, proptereā quod nōlō (vel nōluī) tē eī id dìcere;
(c) Retineō tē nē hoc dịcās; vel
(d) Retinuĩ tē nē hoc dīcerēs. 
III. In sententiīs $(b)$ et $(d)$ suprā scrīptīs, novam verbī fōrmam habētis quam Tempus Imperfectum Modī Subiūnctīvī appellāmus.

Habētis igitur

\section{A. Fōrmulam VI.}

Fècit hoc quō nōbilior fieret.

Imperāvit militibus ut óppidum intrārent.

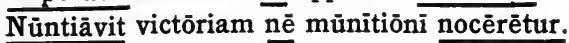

Appellāvit equitem quī portam aperīet.

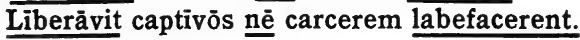

Tempus Imperfectum Modī Subiūnctīivi:

Fierem,

Fierēmus,

Intrārem,

Intrārēmus,

Nocērem,

Nocērēmus,

Aperirem, Aperīēmus, fierēs, fierētis, intrārēs, intrārētis, nocērēs, nocērētis, aperīès, aperïētis, fieret. fierent (-induerem). intrāret. inträrent (- spectārem). nocëret. nocērent (- torquërem). aperiret. aperirent ( - ferirem).

Labefacerem, labefacerēs, labefaceret.

Labefacerēmus, labefacerētis, labefacerent (- raperem).

B. Sententiae Fōrmulae VI suprā scrīptae hōc modō cōnformārī possunt, sī Tempus Praesēns ūsūrpāmus:

Facit hoc quō nōbilior fiat. Imperat militibus ut oppidum intrent.

$\overline{\overline{\text { üntiat }}}$ victōriam ñē mūnītiōni noceătur.

Appellat equitem qui portam aperiat. Liberat captivōs nē carcerem labefaciant. 


\section{PĒNSUM XLIV}

Omnēs gentēs ēsuriēbant, et manūs ad Iovem tollēbant petentēs ut populōs servāret. Illī enim prōvidēre nōn poterant nē ūniversī famē opprimerentur et perīrent. Tam diū querēbantur quam diū Iuppiter resis5 tēbat; et tandem tot precibus superātus deus statuit Proserpinam līberāre, hāc tamen condīciōne, ut puella iūrāre posset sē nihil in rēgnō Plūtōnis ēdisse. Itaque Cerēs ipsa prōfecta est ut fīliam sūmeret, et iam paene effēcerat id quod voluit, Plūtōne invītō.

10 Sed umbra quaedam illās prohibēbat nē ex regiōnibus mortis exīrent, cupiēns ut puella longē à superīs semper habitāret. Cognōverat enim, quod Proserpina fortasse iam oblīta erat, eam illō ipsō diē sex sēmina mālī Pūnicī èdisse. Lacrimae nihil valuērunt; nōn licuit

15 puellae tōtum annum in terrā versārī, sed necesse erat sex mēnsēs in utrāque regiōne vīvere. Ubi in nostrā terrā est, nātūra plūrimīs flōribus ōrnātur, avēs cantant, nāscuntur et crēscunt omnia, ut per reliquam partem. anni vïtam sustineant et per longam hiemem 20 ad edendum ūtilia sint. Sed ubi invita sub terram dēscendit, caelum lacrimat, undique mūtantur omnia, nē gentēs hūmānae mortis oblīvīscī incipiant, nec iam "Mementō morī" dīcant. Poenam dat nātūra quod haec optima puella sex sēmina comēdit, et umbra illa 25 malevolēns ea quae perspexerat Plūtōnī dētulerat. Grātiās dīs omnibus oportet agĩ quod sex potius quam duodecim ēdit, nam nunc quidem plērīque putant nōs vix satis longam habēre aestātem, nimis longam hiemem patì. 


\section{PĒNSUM XLV}

I. Sī nunc puerum spectās et huius puerī nōmen scīre volō, hoc quaerō, "Dīc mihi quem spectēs." (Vidē in Pēnsō XLI "Rogō.") Quodsī antehāc hunc puerum spectābās vel spectāvistī vel spectāverās, hoc quaerō, "Dìc mihi quem spectāverīs." Hoc verbum (spectāverīs) in Tempore Perfectō Modī Subiūnctīvī est.

II. Sì iam antehāc puerum spectāverās, et eius nōmen scīre voluī vel volēbam, tum quaesīvī (quaerēbam) quem spectāvissēs. Hoc verbum (spectāvissēs) in Tempore Plūsquamperfectō Modī Subiūnctīīi est. Fōrmās igitur et sententiās īnfrā habēmus.

A. Tempus Perfectum Modī Subiūnctīvī:

Percusserim, percusseris, percusserit.

Percusserimus, percusseritis, percusserint.

Induerim,

Rapuerim, indueris,

Percussus sit; percussī sint;

Indūtus sit; raptus sit; et cētera.

B. Tempus Plūsquamperfectum Modī SubiūncTĨ İ:

Percussissem, percussissēs, percussisset.

Percussissēmus, percussissētis, percussissent.

Spectāvissem, spectāvissēs, spectāvisset, et c.

Torsissem, torsissēs, torsisset, et c.

Percussus esset; percussi essent;

Spectātus esset; tortus esset; et cētera. 
C. Animadvertite summā cum cūrā quae tempora ūsūrpentur:

Sciō quem nunc spectēs et quem antehāc spectāverīs.

Scièbam quem illō tempore spectārēs et quem iam antehāc spectāvissēs.

D. Etiam coniūnctiōnem cum habēmus; respondet quaestiōnī quandō, vel quaestiōnī cūr ; hī ambō ūsūs in sententiīs înfrā scrīptīs illūstrantur. Tertiam quoque significātiōnem habet cum, quae hāc sententiā illūstrātur; Cum caecus sit, tamen beātus est; id est, Caecus est, sed tamen beātus est. In hāe significātiōne cum eadem tempora et modōs habet quae cum quod quaestiōnī cūr respondet. Sequitur

\section{Fōrmula VII:}

Quandō, Ō turpis, dormis? Cum labor adest (aderit, adfuit), dormiō.

Cür, Ō turpis, dormis? Cum labor adsit (adfuerit), dormiō.

(Possumus ūsūrpāre dormìvistī, dormīvì, sĩ tempus perfectum, nōn tempus praeteritum, significātur.)

Quandō, Ō audāx, pugnābās? Cum hostēs adorīrentur (adortī essent), pugnãbam.

Cūr, Ō audāx, pugnābās? Cum hostēs adorïrentur (adortī essent), pugnābam.

(Possumus ūsūrpāre pugnāvistī, sĩ tempus praeteritum, nōn tempus perfectum, significātur: vel possumus ūtī pugnāverās.)

Quandō, Ō iūste, superābis? Cum iūs valēbit (valuerit, dicātĩvum) superābō.

Cūr, Ō iūste, superābis? Cum iūs valeat (valuerit, - subiūnetĩvum) superābō.

(Possumus ūsūripāre superāveris in locō vocābulī superābis.) 


\section{PĒNSUM XLVI}

Cum iam fābulās dē hominibus pernōtās, nōnnūllās etiam dē dīs et deābus antīquīs minus nōtās audīverītis, dē bellō antīquissimō nunc nārrābō. Vōs omnēs dē Caesare scītis, cum clārissimus imperātor omnium Rōmānōrum fuerit. Cum in Belgīs bellum gereret, 5 multās nātiōnēs facile superābat, sed Nerviī sē trādere nōlēbant; lēgātiōnem ad Caesarem nōn mittēbant, pācem recūsābant, cum sē Rōmānīs virtūte praestāre putārent. Quārē Cacsar cōnstituit Nerviōs vincere.

Audīverat eōs trāns Sabim flūmen exercitum cōnstitu- 10 isse, ubi impetum Rōmānōrum exspectābant. Proximae flūminī erant silvae, in quibus omnēs cōpiās tenēbant. Ab utrāque rīpā flūminis nāscēbantur collēs; in alterā cum essent hostēs, in alterā Caesar castra posuit. Ut mōs erat cum hostibus appropinquāret, sex legiōnēs 15 praemīsit quae castra mūnīrent, equitātum ad flūmen mīsit quī hostēs pellerent. Sed cum hī ad rīpam vēnissent, Nerviī in eōs vehementer impetum fēcērunt, et usque ad vāllum castrōrum Rōmānōrum persequēbantur. Cum mīlitēs in opere occupātī essent, quīdam 20 praetereā longius aggeris petendī causā prōcessissent, tamen Caesar omnēs celeriter revocāvit, aciem īnstrūxit, signum pugnandī dedit.

Propter celeritātem hostium omnia nōn secundum ōrdinem reī mīlitāris fiēēbant. In sinistrā parte aciēī 25 īnstitūta erat decima legiō cui praeerat Labiēnus lēgātus; contrā hanc pugnābant sociī Nerviōrum, Atrebatēs nōmine; hī nē paulisper quidem resistēbant, sed in flūmen reiectī sunt; ad postrēmum vix ūnus super- 
30 fuit. Cum castra ā fronte quoque nūdāta essent, unde militēs hostēs persequentēs discesserant, omnēs Nerviī, ab illō ductī quĩ summam imperī tenēbat, ad hunc locum contendērunt. Castra facile occupābant, quod cum vĩdissent, eĩ quĩ cum impedīmentīs veniēbant per35 territĩ fugiēbant.

\section{PẼNSUM XLVII}

Perlegite iterum capita I et II Pēnsī XLIII. Deinde haec animadvertite.

I. Sententiās plānē explicō (vel explicāvī); itaque eās intellegitis (vel intellēxistis). Id est:

(a) Tam plānē explicō ut intellegātis; vel

(b) Tam plānē explicāvì ut intellegerētis.

II. Quodsĩ nōn plāna sed obscūra est (vel erat) explicātiō:

(c) Tam obscūrē explicō ut nōn intellegātis; vel

(d) Tam obscūrē explicāvĩ ut nōn intellegerētis.

Habēmus igitur

Fōrmulam VIII:

Ratiō ea (tâlis) est quae ab omnibus probētur (probāta sit).

Exemplum tam commodum dedit ut rẹm lūcide explānāret.

Sententiās tam facilēs prōpōnam ut omnēs cōnscribere possint.

Ūsum scribendĩ tam singulārem magister habuerat ut nēmō scriptūram legere posset.

Litterãs ita scripserit ût classis significātiōnem nōn intellexerit.

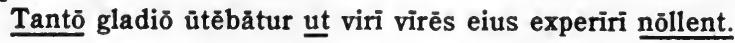



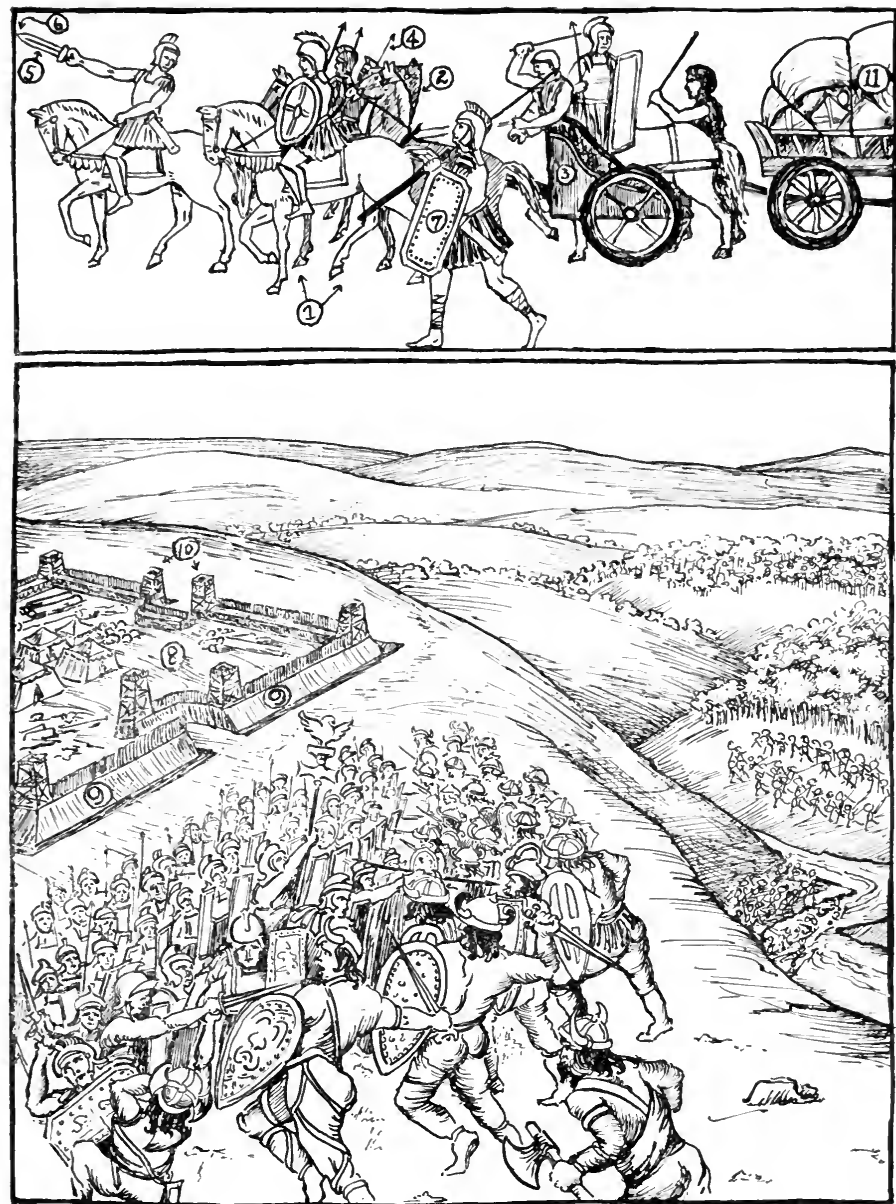

\section{Castra et Proelium Caesaris}

1. equitātus. 2. equī. 3. currus. 4. hasta. 5. gladius. 6. mucrō. 7. scūtum. S. castra. 9. agger. 10. turrềs. 11. impedìmenta. 


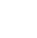




\section{PẼNSUM XLVIII}

Itaque ēvēnit ut fortūna Rōmānōs paene dēsereret. Equitēs Trēverōrum, quī sociī erant, quoniam legiōnēs premī et hostēs castra obtinēre vidērent, ad suam cīvitātem revertērunt. Rōmānōs victōs esse et spem salūtis āmīsisse renūntiāvērunt. Sed Caesar, sīc ut saepe anteā fēcerat, et mīlitibus et centuriōnibus et tribūnīs et lēgātīs fidem integram habēbat; quam quidem opīniōnem virtūtis merēbantur. Ad dextrum cornū profectus est, ut subsidium suīs ferret; sed Nerviī tam vehementer eōs premēbant ut duodecima legiō, et 10 praesertim cohors quārta, vix resistere posset. Caesar prīmum mīlitī scūtum dētrāxit, quod ipse tam celeriter vēnerat ut omnia quae ad arma pertinērent sēcum nōn attulisset; deinde tam ācriter pugnāvit ut etiam volnerātī peditēs ultrō similēs integrīs fierent et prīncipem 15 sequerentur.

Multum adiuvābant legiō septima quoque et duae legiōnēs quibus negōtium fuerat ut post commeātuī subsidiō venīrent. Illī quidem quī ad ulteriōrem partem castrōrum fūgerant, quod timērent nē occīderentur, 20 nōn iam perīculum vidēbant, et sine tēlīs pugnābant. At hostēs Rōmānīs virtūte parēs erant; cum prīmī cecidissent, posterī in eōrum locum prōcessērunt, et corporibus eōrum institērunt, ut quasi à castellō vel turrī tēla in nostrōs conicerent. Neque ūllī ex multīs mīli- 25 tibus volnus $\bar{a}$ tergō accēpērunt.

Postrīdiē eius diēī, post victōriam Rōmānōrum nūntiātam, maiōrēs nātū Caesarī suōs pūblicē dedidērunt. Ex senātū dīxērunt trēs sōlōs superesse, et sē potestā- 
30 tem suam tōtam āmīsisse, neque rēs pūblicās neque prīvātās iam habēre. Caesar eōs ōrātiōne benignē cohortātus est, neque obsidēs postulāvit; haec quoque beneficia illīs dedit; suōs vīcōs permīsit ut retinērent, et fīnitimīs, quī neque familiārēs neque necessāriī es35 sent, imperāvit ut ab ūllā suspiciōne iniūriae sē suōsque prohibērent.

\section{PĒNSUM XLIX}

Sequuntur octō sententiae, quibus illūstrantur genera casūs “Ablātīvī Absolūtī," quī appellātur. Sententiae bīnae scrīptae sunt, et rē vērā idem significant ambae quās sīc coniūnctās vidētis.

Cum lēx cognita esset, tum cōnsul officium nōn dèseruit. Lège cognitā, cōnsul officium nōn dēseruit.

Cum prōvincia servāta esset, eā dē causā quaestor imperātōrì praemium dedit.

Prōvinciā servātā, quaestor imperātōrī praemium dedit.

Cum ventus surgat, tamen magnum numerum nāvium nōn vidèmus.

Ventō surgente, magnum numerum nāvium nōn vidēmus.

Si soror parāta est neque caput movet, tum frāter hastam iacit.

Sorōre parātā neque caput movente, hastam iacit.

Quondam fuit apud Rōmānōs puella pulcherrima, nōmine Lara. Huius pulchritūdinem mīrābantur omnēs, maximē tamen loquāx erat, neque ā prīmā hōrā diēì usque ad vesperum tacēbat. Iove quondam cum 5 dēliciīs suīs colloquente, audīvit Lara, et omnia Iūnōnī 
nārrāvit. Hāc rē mox cognitā, Iuppiter valdē īrātus Laram comprehendit et, laniō terribilī adhibitō, perfēcit ut lingua puellae abscīderētur. Deinde Mercuriō imperāvit ut Laram ad concilia inferōrum dūceret, ubi linguā abscīsā in aeternum mūta manēret. Itaque 10 deus, puellā comitante, ad rēgna Plūtōnis profectus est. Sed Lara, linguā nōn iam sē movente, multō blandior erat quam anteā fuerat, et Mercuriō tantopere placuit ut, nūllō mōmentō temporis praetermissō, illam adamāret et in mātrimōnium dūceret. Ab hīs 15 nātī sunt duo fīlī̄, quī Larēs appellātī sunt. Omnis domus Rōmāna hōs deōs prope focum habēbat; quōrum ad pedēs iacēbat canis semper lātrāns, quī significāret Larēs semper vigilāre et domum cūstōdīre.

\section{PĒNSUM L}

Gāium Iūlium Caesarem omnēs cōnsentiunt clārissimum fuisse Rōmānōrum; itaque quaedam dē illīus vìtā nōbīs audienda sunt. Dỉcunt illum prīmīs annīs $\bar{a}$ L. Sullā agitātum esse, quod ille iuvenem timuerit; et Caesarem quondam ā tālī fugā revertentem ā pīrātīs $s$ captum esse; quōs autem illum nōn necāvisse, sed pretiō līberāvisse. Hīs Caesar dīxerat sē omnēs crucī affixūrum esse, quod quidem nōn crēdidērunt; sed statim reversus tōtam manum cruce necāvit, quamquam propter misericordiam prīmum iugulāvit.

Dictum est illum quondam in Hispāniā imāginem Magnī Alexandrī vīdisse, et ingemuisse quod nihil dum $\bar{a}$ sē memorābile actum esset, in aetāte quā iam Alex- 
ander orbem terrārum subēgisset. Audīmus illum post

15 bella Gallica fīnīta, cum Pompēius illum arma trādere iusserit, ad Rubicōnem flūmen cōnstitisse, quod sī flūmen trānsīverit bellum cīvīle statim fīat. Sed mox dīxit "Iacta ālea estō," et trānsiit.

Āiunt illum quondam cum aliīs apud hospitem cēnā20 visse; sed quod asparagī unguentō nōn oleō parātī sint, cēterōs recūsāvisse. Ille autem dīxit satis malum esse cibum hospitis recūsāre, sed quĩ urbānitātem alterius calumniārētur, ipsum suam urbānitātem negāre. Narrātur illī quondam nūntiātum esse Pharnācem rēgem in Pontō contrā populum Rōmānum cum aliīs rēgibus 25 coniūrāre; quod cum Caesar audīverit, rēgem tam celeriter vīcisse ut hunc nūntium remīserit: "Vēnī, Vìdī, Vīci."

Iam ad mortem illīus pervēnimus. Multī Rōmānī eum ōdērunt, quod rēx esse volt. Semper vīta eius 30 perīculōsior fit. Dīcit illī haruspex quīdam: "Cave perīculum, quod nōn ultrā Mārtiās Īdūs prōferētur." Multa sunt portenta. İdibus Martī̄s in senātum venit. Coniūrātī eum circumstant. Casca cōnfodit. Brūtum videt Caesar. "Et tū, Brūte," graecē exclāmat, et 35 vïgintī tribus volneribus cōnfossus animam agit. 


\section{APPENDIX GRAMMATICUS}

I. Dēclīnantur nōmina in Pēnsō XIX. (Mas. et Fēm. Acc. Gen. Dat. Abl.)

Dēclīnạntur nōmina in Pēnsō XXII. (Mas. et Fēm. Nōm.)

Dēclīnantur nōmina in Pēnsō XXV. (Neutra.)

Dēclīnātur prōnōmen relātīvum in Pēnsō XXXIV.

II. Comparantur adiectīva in Pēnsō XXIX.

III. Coniugantur verba in Pēnsō I. (Praes. Indic. et Imper. Act. Sing.)

Coniugantur verba in Pēnsō II. (Praes. Indic. et. Imper. Act. Plū.)

Coniugantur verba in Pēnsō VI. (Praes. Īnfīn. Act.)

Coniugantur verba in Pēnsō XIV. (Praet. Indic. Act.)

Coniugantur verba in Pēnsō XV. (Praet. Īnfīn. Act.)

Coniugantur verba in Pēnsō XXXI. (Fut. Indic. et Infīn.)

Coniugantur verba in Pēnsō XXXIII. (Plūsquamperf. et Fut. Perf. Indic.)

Coniugantur verba in Pēnsō XXXV. (Imperf. Indic.)

Coniugantur verba in Pēnsō XLI. (Praes. Subiūnc.) 
Coniugantur verba in Pēnsō XLIII. (Imperf. Subiūnc.)

Coniugantur verba in Pēnsō XLV. (Perf. et Plūsquamperf. Subiūnc.)

Coniugantur verba in Pēnsō XXXVIII. (Participia.)

IV. Coniugātur verbum quod est $e \bar{o}$ in Pēnsīs IV, XIV, XLI.

Coniugantur verba quae sunt sum et possum in Pēnsīs XXIII, XXXI, XLI.

Coniugantur verba quae sunt volō, nōlo, mālo in Pēnsīs XXXVIII, XLI. 


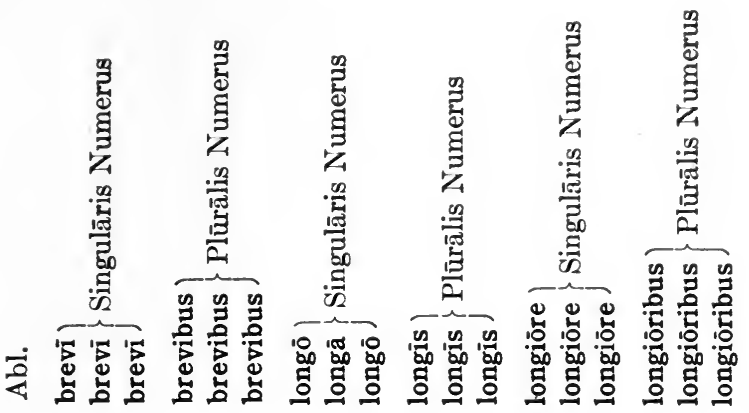

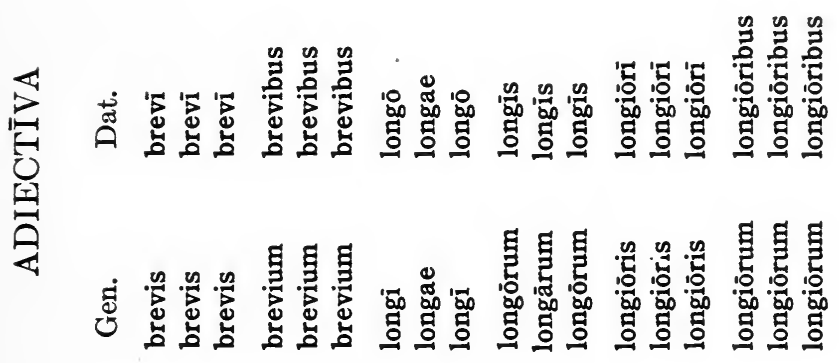

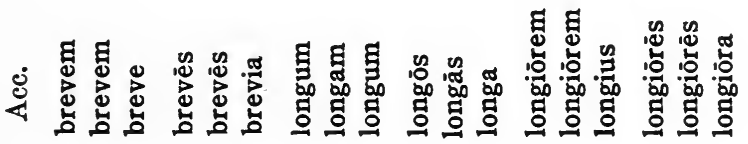

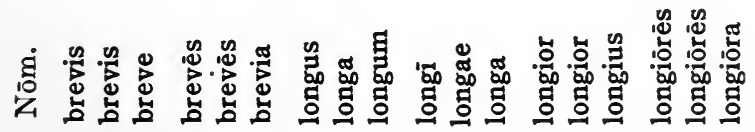

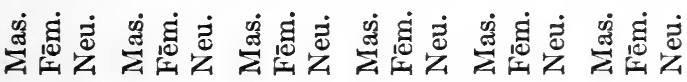



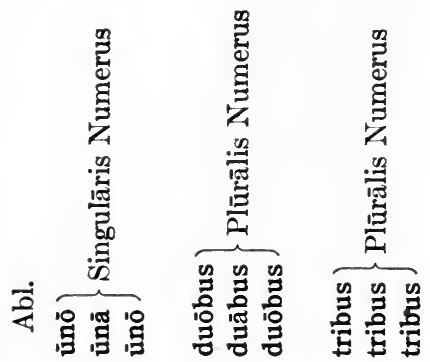

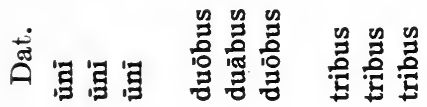

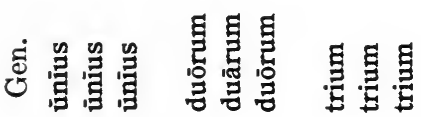

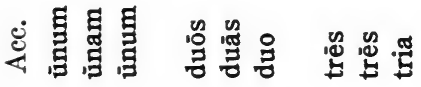

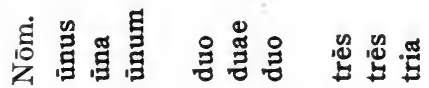

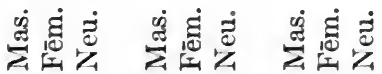
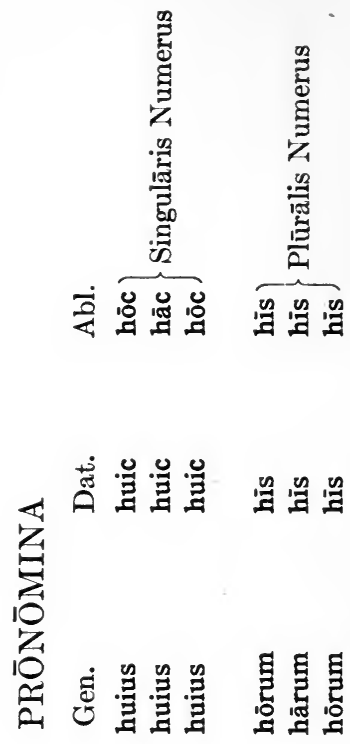

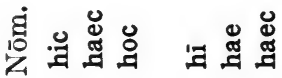

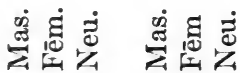




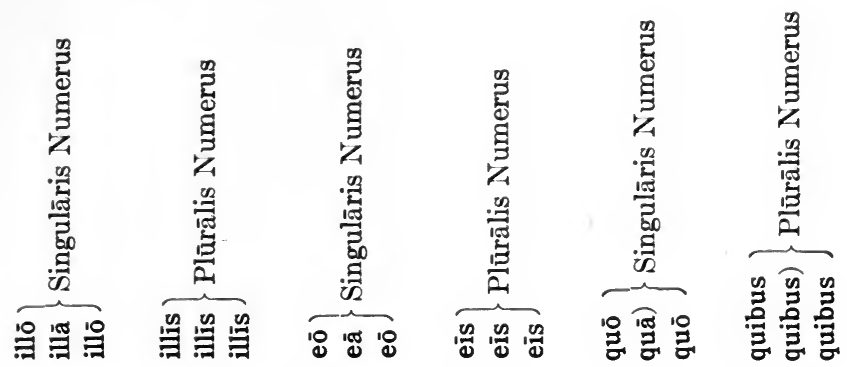

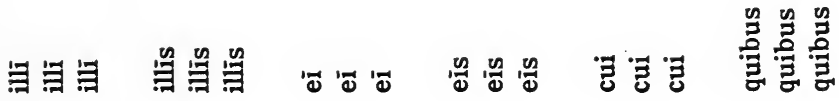

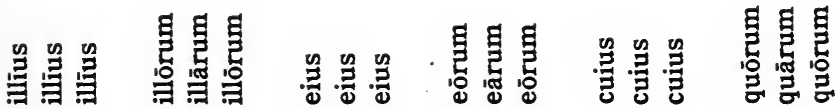

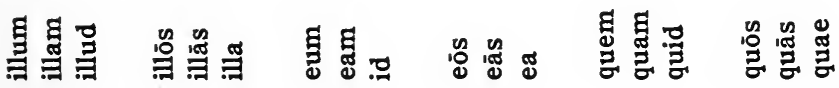

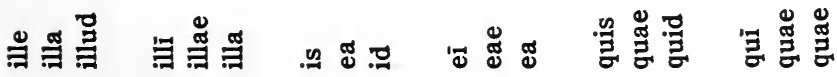

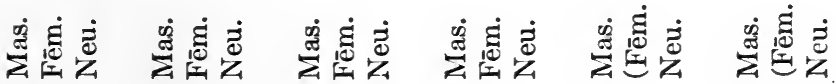



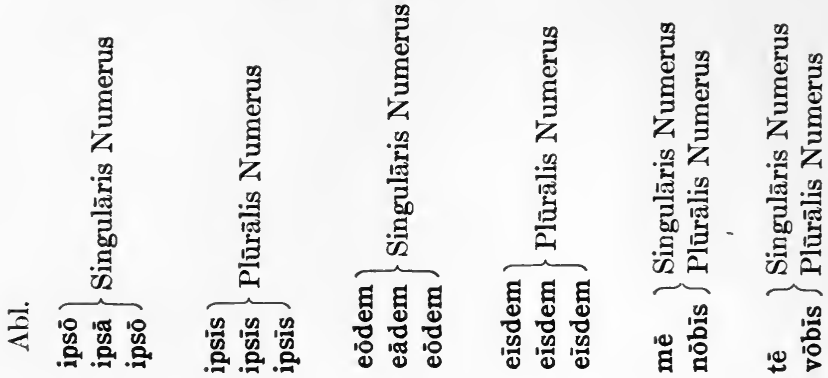

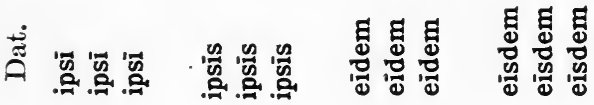

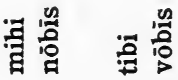
焉焉

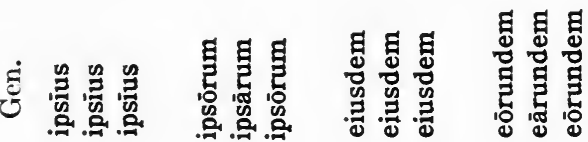

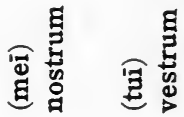

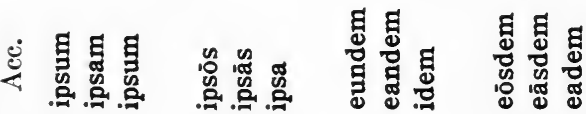
曽管哭

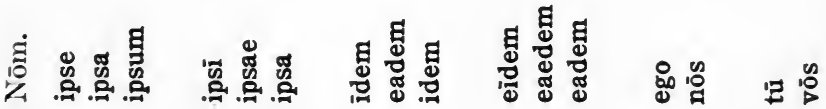

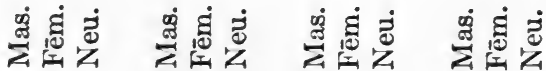




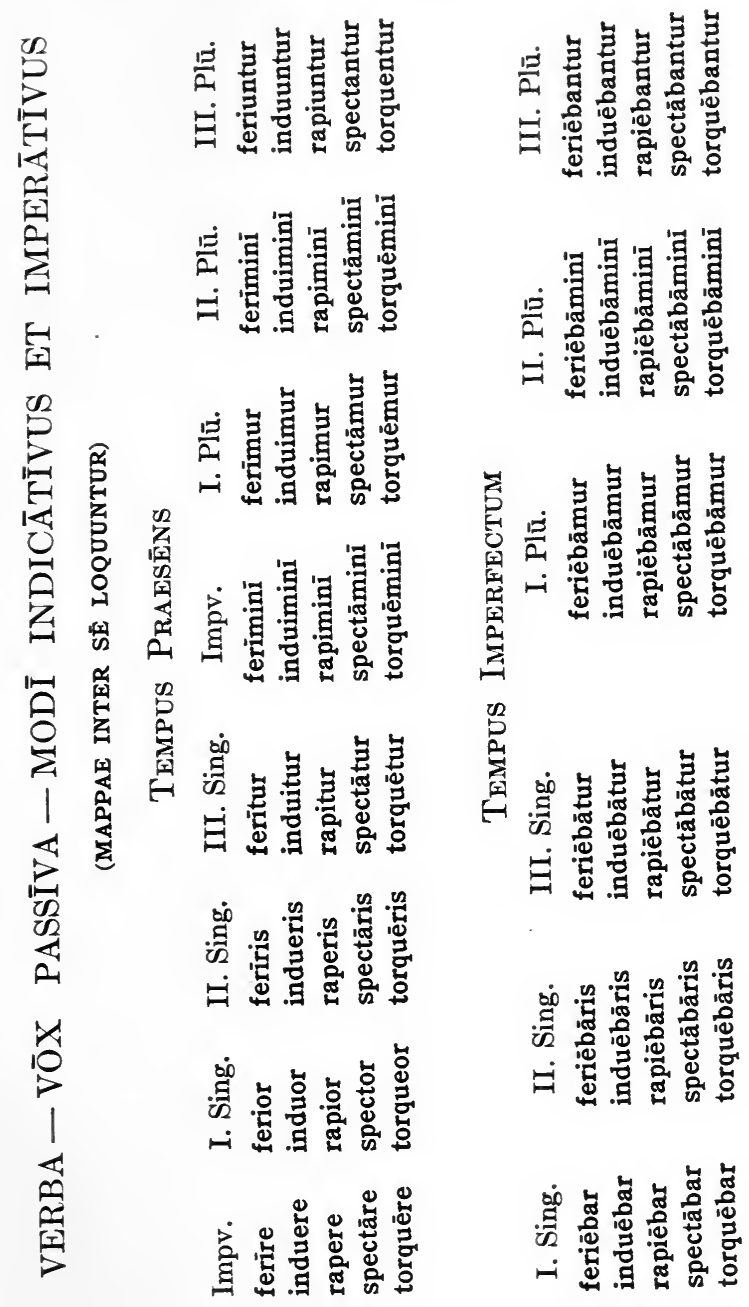




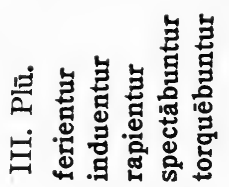

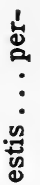

:

岁

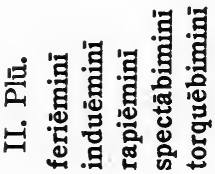

趂

㟧

象

o

of

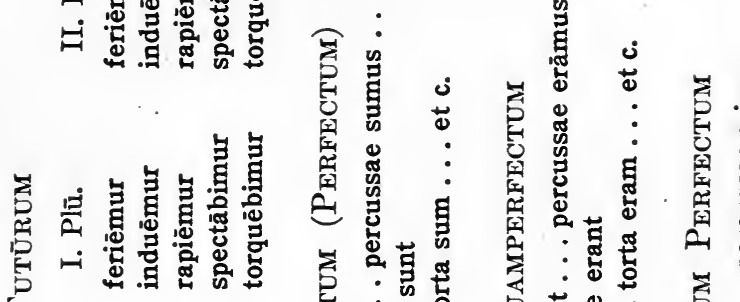

采

畜

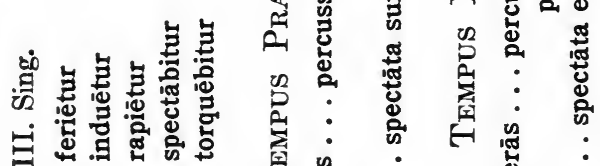

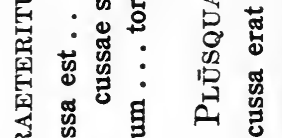

的界

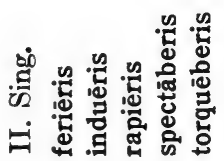

要

㐘

$:$ 品

自

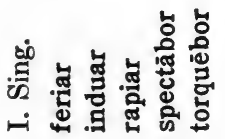

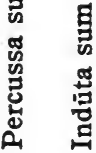

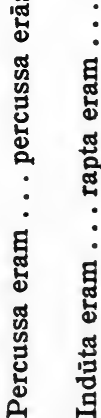

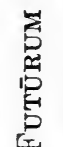

$+$

- 둔

苋

垴

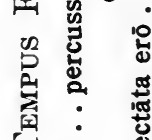

密

:

要:

:

垴

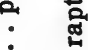

웅

客

号

这 

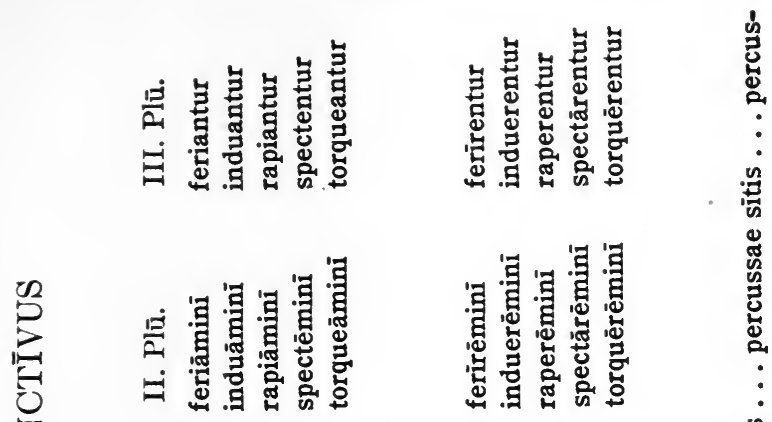

总

舟

$\sum_{0}^{0}$ D

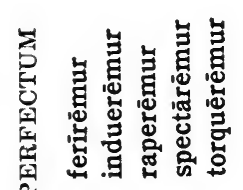

畜

穿

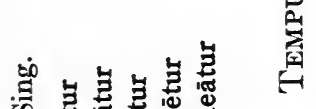

至毞志志

设

晋

岁

扂

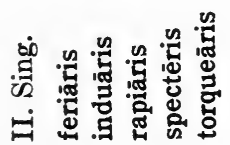

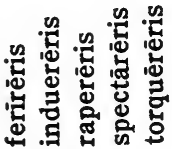

四

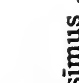

党

ن

营:

$\because$ :

$\div$ 㫣.

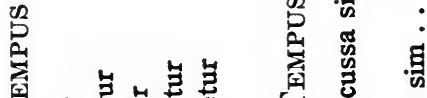

范 芯

-

-

ตี :

递寄

\&.

-

:

离

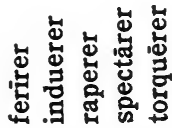

章 


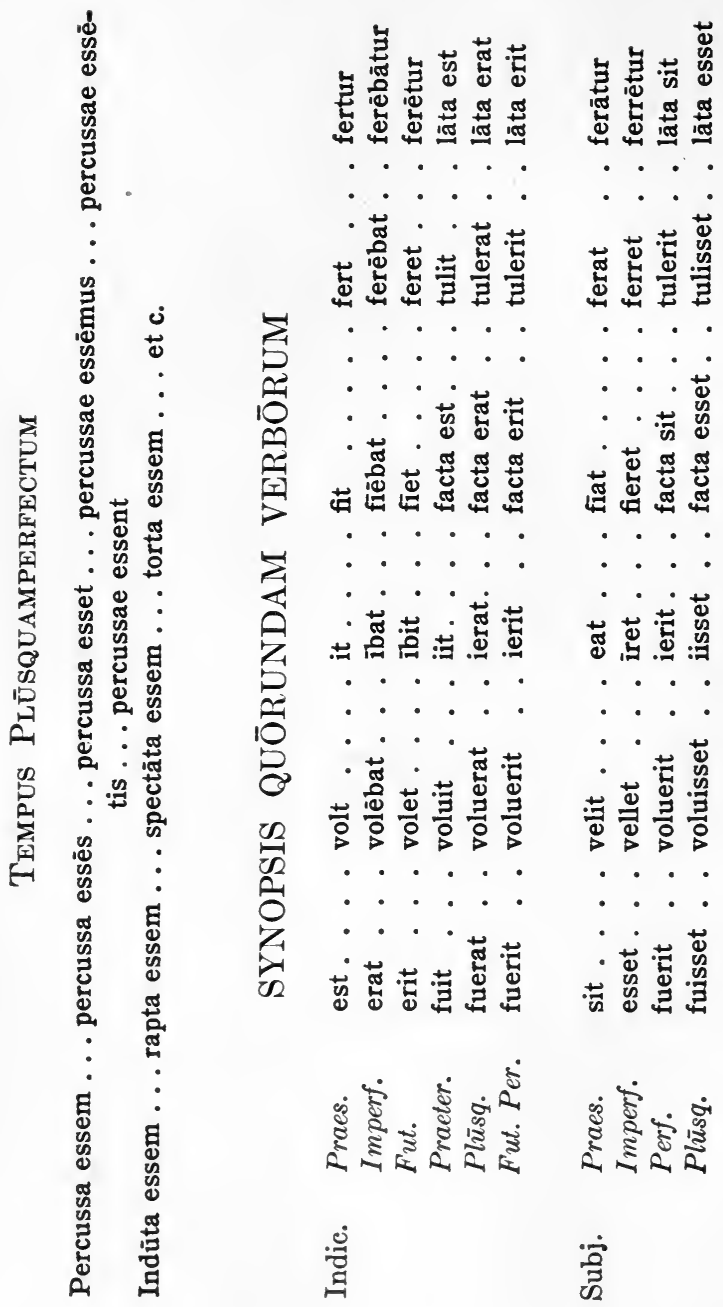




\section{POẼMATA}

I. Humtius in mūrō requiēvit Dumtius altō;

Humtius ē mūrō Dumtius heu cecidit.

Sed nōn rēgis equī, rēgīn(ae) exercitus omnis,

Humtī, tēe, Dumtī, restituēre locō.

II.

$\overline{0}$ mea Maria,

Tōta contrāria,

Quid tibi crēscit in hortō?

Testae et crotalī

Sunt mihi flōsculī,

Cum hyacinthinō sertō.

III. Hei didul(um), atqu(e) iterum didulum. Fēlēsque Fidēsque.

Vacca super lūnae cornua prōsiluit. Nesciō quā catulus rīsit dulcēdine lūdī;

Abstulit et turpī lanx cochleāre fugā.

IV. Cordium Rēgīna fēcit

Quam suāvissimās placentās

Diē dīligēns aestīvō.

Cordium Fūr ille prīmus,

Prīnceps ìdem prīmō nātus,

Fūrābātur hās placentās,

Penitusque subtrahēbat.

Cordium Rēx īrācundus

Nōrat perditās placentās,

Ācriterque verberāvit 
Fūrem simul fĩliumque.

Reddiditque Fūr placentās,

Prīnceps īdem prīmō nātus,

Cordium Fūr ille prīmus,

Neque rūrsum spoliāvit.

V. Mìca, mīca, parva stella,

Mīror quaenam sīs tam bella,

Splendēns ēminus in illō,

Alba velut gemma, caelō.

Quandō fervēns sōl discessit,

Nec calōre prāta pascit,

Mox ostendis lūmen pūrum,

Mīcāns, mīcāns per obscūrum.

Tibi, noctū quĩ vagātur,

Ob scintillulam grātātur;

Nì mīcārēs tū, nōn scīret

Quās per viās errāns īret.

Meum saepe thalamum lūce

Speculāris cūriōsa;

Neque carpseris sopōrem

Dōnec vēnit sōl per auram.

VI. Strīdet ventus Boreālis,

Imber ingruet nivālis:

Quō sē vertet hōr $(\bar{a})$ in illā

Rubicilla?

In grānāriō sedēbit,

Plūmeā tepēns fovēbit

Molle caput sub axillā

Rubicilla. 
VII. Ille citharistae fîlius,

Thōmās, Thōmās nōminātus,

Porculō surreptō currit:

Porcus cito mandūcātus,

Thōmās, cito verberātus,

Ululāns per vīcum fūr it,

Ululāns per vīcum furit.

VIII.

Nōs dum pilā lūdimus,

Victĩ seu victōrēs,

Vel in circō currimus,

Rapidī cursōrēs,

Vel in turbā tollimus

Cōnsonōs clāmōrēs,

Tum nōn tantī facimus

Nostrōs professōrēs.

Sed sī scamna premimus

Multōs per sūdōrēs,

Et cum cūrā volvimus

Improbōs labōrēs,

Et in ōre sentīmus

Surgere rubōrēs,

Magis iam suspicimus

Nostrōs professōrēs.

Tum in exāminibus

Quantī sunt horrōrēs.

Paenitet nōs penitus

Nōn mūtāsse mōrēs.

Inter nōs aspicimus 
Voltuum pallōrēs, Et timēmus funditus

Nostrōs professōrēs.

Sed sī perreptāvimus .

Tantōs hōs terrōrēs,

Hilarēs resurgimus

Ut ex imbre flōrēs.

Alacrēs requîrimus

Veterēs amōrēs,

Nec iam tantī facimus

Nostrōs professōrēs. ${ }^{1}$

IX.

Gaudeāmus igitur, Iuvenēs dum sumus;

Post iucundam iuventūtem,

Post molestam senectūtem,

Nōs habēbit humus.

Ubi sunt, quī ante nōs

In mundō fuēre?

Transeās ad superōs,

Abeās ad inferōs,

Quōs sĩ vīs vidēre.

Vita nostra brevis est, Brevī fīniētur;

Venit mors velociter,

Rapit nōs atrociter,

Nēminī parcētur.

1 Printed by permission of the author, Professor W. H. Kirk, of Rutgers College. 

Alma māter flōreat,
Quae nōs.ēducāvit,
Cārōs et commīlitōnēs,
Dissitās in regiōnēs
Spparsōs, congregāvit.
Vīvat et rēpūblica
Et quī illam regit,
Vìvat nostra cīvitās,
Maecēnātum cāritās.
Quae nōs hīc prōtegit.

X. Integer vītae, scelerisque pūrus

Nōn eget Maurīs iaculīs neq(ue) arcū, .

Nec venēnātīs gravidā sagittīs,

Fusce, pharetrā;

Sīve per Syrtēs iter aestuōsās

Sīve factūrus per inhospitālem

Caucasum, vel quae loca fābulōsus

Lambit Hydaspēs.

Namque mē silvā lupus in Sabīnā

Dum meam cantō Lalagēn, et ultrā

Terminum cūrīs vagor expedītīs,

Fūgit inermem.

XI. Lūgēt(e), ō Venerēs Cupīdinēsque;

et quant(um) est hominum venustiōrum.

passer mortuus est meae puellae.

passer, dēliciae meae puellae,

quem plūs ill(a) oculīs suīs amābat: 
nam mellītus erat suamque nōrat ipsam tam bene quam puella mātrem. nec $\operatorname{sēs}(\overline{\mathrm{e}})$ ā gremi(̄o) illius movēbat, sed circumsiliēns $\bmod (\mathrm{o})$ hūc, $\bmod (\mathrm{o})$ illūc, ad sōlam domin(am) usque pīpilābat. quī nunc it per iter tenebricōsum illūc, unde negant redīre quemquam. at vōbīs male sit, malae tenebrae Orcī, qu(ae) omnia bella dēvorātis: tam bellum mihi passer(em) abstulistis. vae factum male! vae miselle passer, tuā nunc operā meae puellae flendō turgidulī rubent ocellī.

XII. Dīsertissime Rōmulī nepōtum, Quot sunt quotque fuēre, Mārce Tullī, Quotque post alīis erunt in annīs, Grātiās tibi maximās Catullus Agit, pessimus omnium poēta, Tantō pessimus omnium poēta Quantō t(ū) optimus omnium's patrōnus. 


\section{INDEX VERBŌRUM}

A

$\bar{A}$ vel Ab (cum abl.) (xIx) . . . (in Fōrmulā Iv).

Abdō, abdere, abdidī, abditum

(xxxıv) . . . . . . . (pōnō ubi nōn facile reperīs).

Abdūcō, abdūcere, abdūxī, ab-

ductum (xviII) . . . . . (ab+dūcō).

Abeō, abīre, abiī, abitum

(xv) . . . . . . (ab+eō).

Abscīdō, abscīdere, abscīdī, ab-

scīsum (xLIx) . . . . . (ab aliquō caedō).

Absēns, absēns (gen. absentis)

(viII) . . . . . . . (rogā magistrum).

Abstergeō, abstergēre, abstersī,

abstersum (II) . . . . . (rogā magistrum).

Absum, abesse, abfuī (xxxiv) . (ab+sum: cf. Absēns).

Accēdō, accēdere, accessī, accessum (xxvi) . . . . . (appropinquō).

Accidō, accidere, accidī (xLII) (accidit - venit id quod nōn exspectāmuș).

Accipiō, accipere, accēpī, acceptum (xIx) . . . . . (in Fōrmulā IV).

Ācer, ācris, ācre (xxvi) . . . (ferus: bonus culter ācer est).

Acerbus, acerba, acerbum (xv) . (contrārium est Dulcis).

Aciēs, aciēī, $f$. (xLvı) . . . (ācris pars alicuius: mīlitēe ad pugnam paràtīi).

Ad (cum acc.) (Iv) . . . . . (in Fōrmulā III).

Adamō, adamāre, adamāvĩ, adamātum (xxıv) . . . . . (maximē amō). Addō, addere, addidī, additum (xvi) . . . . . . . (in Fōrmulā Iv). 
Addūcō, addūeere, addūxī, adductum (xxxiı) . . . . ( $(\mathrm{ad}+\mathrm{dū} c o ̄)$.

Adferō, adferre, attulī, allā$\operatorname{tum}(\mathrm{xL})$. . . . . . $(\mathrm{ad}+\mathrm{fero})$.

Adficiō, adficere, affēcī, affectum $\left(\mathrm{xI}_{2}\right)$. . . . . . (aliquid alicui faciō).

Adhibēō, adhibēre, adhibuī, adhibitum (xLIX) . . . . (ūtor: dīcō "Hũe venī").

Adhūe (xL) . . . . . . . (ad hoc tempus).

Adiectīvum, adiectīvī, $n$. (xxvi) (e.g., Bonus, Gravis).

Adiuvō, adiuvāre, adiūvī, adiūtum (xlviı) . . . . . . (iuvō).

Adorior, adorīrī, adortus sum (xL) . . . . . . . (orior et ad aliquem eō).

Adōrō, adōrāre, adōrāvī, adōrātum (xxxıv) . . . . (rogō aliquem: rogō deum). Adsum, adesse, adfuī (xxıv) . . (praesēns sum). Adulēscēns, adulēscentis, $m$.

(xxI) . . . . . . . (iuvenis maior).

Adveniō, advenīre, advēnī, adventum $(\mathrm{x})$. . . . . . (ad+veniō $)$.

Adventus, adventūs, $m$. (x) . . (sī mē advenīre vidēs, adventum meum vidēs).

Advertō, advertere, advertī, adversum $(\mathrm{xL})$. . . . . (ad+vertō).

Aedēs, aedium, $f .(\mathrm{xxI})$. . . (magna villla).

Aedificium, aedificī, $n$. (xxvi) . . (aedēs).

Aeger, aègra, aegrum (XL) . . . (nōn bene vītam agēns: nōn validus).

Aequus, aequa, aequum (xL) . . (ìdem: terra aequa montēs nōn habet).

Aestās, aestātis, $f .\left(\mathrm{xL}_{\mathrm{L}}\right)$. . . (pars annī ubi omnia calent). Aetās, aetātis, $f .(\mathrm{xL})$. . . (numerus annōrum alicuius). Aeternus, aeterna, aeternum

(xxıv) . . . . . . (quod nūllum fīnem habet). Affīgō, affīgere, affīxī, affīxum (L) . . . . . . (alieui revinciō). 
Ager, agrī, m. (XIII) . . . . (pict. XIII).

Agger, aggeris, $m$. (XLVI) . . (pict. XLVI).

Agitō, agitāre, agitāìi, agitā-

tum (L) . . . . . . (in omnēs partēs agō).

Agmen, agminis, $n$. (xL) . . . . (illī quōs aliquis dūcit vel agit).

Agōo, agere, ègī, actum (Ix) . . (faciō: sī puerum agōo, ante mē it).

Agricola, agricolae, $m$. (xIII) . . (pict. XIII).

$\overline{\mathrm{A}} \mathrm{i} \overline{\mathrm{o}}$ (xxxII) $\ldots \ldots$. (dīcō).

Ālea, āleae, $f .(\mathrm{L})$. . . . . . . (pict. Xxxvi).

Alius, alia, aliud (Ix) . . (rogā magistrum).

Alter, altera, alterum (xxI) . . (secundus: ūnus ex duōbus).

Altitūdō, altitūdinis, $f .(\mathrm{xx}) \quad \ldots$ (cf. Altus).

Altus, alta, altum (vII) . . . (rogā magistrum).

Alūta, alūtae, $f .(\mathrm{xI}) \ldots$. . (rogā magistrum).

Ambō, ambae, ambō (xxI) . . (duo: alter cum alterō).

Ambulō, ambulāre, ambulāvī, ambulātum (IV) . . . . . . (in Fōrmulā III).

Amīcitia, amīcitiae, f. (xxıv) . . (sī amīcum habeō, amīcitiam cum eō colō).

Amìcus, amīcī, $m$. (xıII) . . . . (is quem amāmus, et quī nōs

Āmittō, āmittere, āmīsī, āmisamat). sum (xıII) . . . . . . . (contrārium est Reperiō). Amō, amāre, amāvī, amātum (xI) . . . . . (rogā magistrum).

Amor, amōris, $m .(\mathrm{xv}) \quad$. . . . (sī amō, amōrem habeō).

Āmovēō, āmovēre, āmōvī, āmōtum $(\mathrm{xxv}) \ldots . . . .(\overline{\mathrm{a}}+$ move $\overline{0})$.

Amplus, ampla, amplum (xL) . (magnus).

Angustus, angusta, angustum (viII) . . . . . . . . (contrārium est Lātus).

Anima, animae, $f .(\mathrm{L}) \ldots$. . (id quod spīrāmus: vïta).

Animadvertō, animadvertere, animadvertī, animadversum $(\mathrm{xxvi}) \ldots \ldots$ (attendō).

Animal, animālis, $n$. (xvir) . (e.g. Lupus, Volpis). 
Animus, animī, $m$. (xxI) . . . (animō meō sentiō, amō, gaudeō, doleō, et c.).

Annus, annī, $m$. (Ix) . . . . (xii mēnsēs).

Ante (cum acc.) (Iv) . . . . . (in Fōrmulā III).

Anteā (xxxiv) . . . . . . (ante id tempus).

Antehāc (xvir) . . . . . (ante hoc tempus).

Antiquus, antīqua, antĩquum

(xxiII) . . . . . (vetus).

Anus, anūs, $f .(\mathrm{xI}) \ldots \ldots$ (pict. $\mathrm{xI})$.

Anxius, anxia, anxium (xxx) . (quī cūrīs opprimitur).

Aperiō, aperīre, aperuī, aper-

tum (II) . . . . . . . (contrārium est Claudō).

Apertus, aperta, apertum (xxIx). (sī quid aperiō, apertum est).

Appellō, appellāre, appellāvī,

appellātum (xxıv) . . . . (alicui nōmen dō).

Appropinquō, appropinquāre,

appropinquāvī, appropinquātum (xvir) ...... (ad rem ēō).

Apud (cum acc.) (xLIX) . . . (prope: inter).

Aqua, aquae, $f$. (III) . . . . (in Fōrmulā II).

Arbitror, arbitrārī, arbitrātus

sum (xxxiv) . . . . . (putō).

Arbor, arboris, $f .(\mathrm{xI})$. . . . (pict. $\mathrm{xI})$.

Arma, armōrum, $n$. (xlvinI) . . (gladius, scūtum, et c.).

Armārium, armārī, $n$. (xxıx) . (pict. xı).

Armō, armāre, armāvì, armā-

tum $(\mathrm{xL}) \ldots \ldots$ ( dō alicui rēs quibus pugnāre

Ascendō, ascendere, ascendī, potest).

ascēnsum (xxI) . . . . . (ad locum superiōrem eō).

Asparagus, asparagī, $m$. (L) . . (pict. Xxxvi).

At (xvII) . . . . . . (sed).

Attendō, attendere, attendī,

attentum (xi) . . . . . (illum quī dīcit spectō et aurēs aperīō).

Attingō, attingere, attigī, attactum (xxxvi) ..... (tangō). 
Auctōritās, auctōritātis, $f .(\mathrm{xL})$. (is quī aliōs agere vel dūcere potest auctōritātem habet).

Audāx, audāx (xxıı) . . . . (eī quĩ audāeēs sunt nihil - timent).

Audeō, audēre, ausus sum (xL) . (contrārium est Timeō). Audiō, audīre, audīīi, audītum

(xIII) . . . . . . . (auribus audiō).

Aureus, aurea, aureum (xxi) . . (rogā magistrum).

Auris, auris, f. (III) . . . . . (in Fōrmulā II).

Auscultō, auscultāre, auscul-

tāvī, auscultātum (xıII) . . . (dēsīderō audīre: aurēs ērigō). Autem (xL) . . . . . . (sed).

Auxilium, auxilī, n. (xL) . . . . (sī cui difficultātem minōrem faciō, illī auxilium ferō).

Avia, aviae, $f .(\mathrm{xI})$. . . . (māter mātris: māter patris). Avis, avis, $f$. (xxxIv) . . . . (pict. XIII).

\section{B}

Bāca, bācae, f. (xL) . . . . . . (parvus frūctus).

Beātus, beāta, beātum (xxI) . . (quī gaudet).

Bellum, bellī, $n$. (xLvi) . . . (multae pugnae inter gentēs).

Bene (xI) . . . . . . . (adverbium: cf. Bonus).

Beneficium, beneficī, $n$.

(xLviI) . . . . . (bonum quod aliquis alicui dat).

Benignus, benigna, benignum

(xxıv) . . . . . . (contrārium est Crūdēlis).

Bibō, bibere, bibī, pōtum (II) . . (in Fōrmulā II).

Bidēns, bidentis, $m$. (xL) . . . (pict. Xxxvi).

Blandus, blanda, blandum

(xLIx) . . . . . . (quī amat, et aliōs ad amōrem dūcit).

Bonus, bona, bonum (viII) . . (rogā magistrum).

Bōs, bovis, $m$. vel $f$. (xviri) . . (pict. xxiII).

Brevis, breve (viI) . . . . (contrārium est Longus).

Brevitās, brevitātis, f. (xx) . . (cf. Brevis). 
C

Cadō, cadere, cecidī, casum (xv) . . . . . . . . (rogā magistrum).

Caedō, caedere, cecīdī, caesum (xxv) . . . . . . . . (cf. Dēcīdō).

Caelum, caelī, n. (xxxıv) . . (omnis locus super nōs, in quō sōl est).

Calamitās, calamitātis, $f$. (xLII) . (id quod male accidit).

Calamus, calamī, m. (Ix) . . (rogā magistrum).

Calceus, calceī, m. (xxx) . . (id quod in pede habeō).

Caleō, calēre, caluī (xxxıx) . . (calor est mihi).

Calor, calōris, m. (xVıI) . . . . (rogā magistrum).

Calumnior, calumniārī, calumniātus sum (L) . . . . (dē aliquō nōn meritō malum dīcō).

Canīnus, canīna, canīnum (xxix) . . . . . . (cf. Canis).

Canis, canis, $m$. (xxirI) . . . (pict. XxiII).

Canō, canere, cecinī, cantum (xxxII) . . . . . . . (pict. XxxiI).

Cantō, cantāre, cantāvī, cantātum (xliv) . . . . . . (canō).

Capillus, capillī, m. (x) . . . (in Fōrmulā Iv).

Capiō, capere, cēpī, captum (II) . . . . . . . . . (contrārium est Pōnō).

Captivus, captīva, captīvum (xL) . . . . . . . (captus).

Caput, capitis, n. (xLIX) . . . (rogā magistrum).

Carcer, carceris, $m$. (xviII) . . . (locus in quō malōs hominēs tenēmus).

Carō, carnis, f. (xxIII) . . . (pict. XxIII).

Carpō, carpere, carpsī, carptum (XII) . . . . . . (pict. XIII).

Carrus, carrī, m. (xxIII) . . . (pict. XxIII).

Castellum, castelī, n. (xlviu) . (castra parva mūnītissima).

Castra, castrōrum, n. (XlVI) . . (pict. XlVI). 
Casus, casūs, $m$. (xLrI) . . . . (id quod accidit).

Catēna, catēnae, $f .(\mathrm{xxI})$. . . . (pict. xxı).

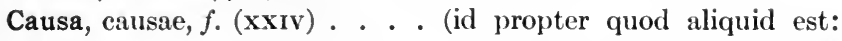

"Causam dīcere" est prō aliquō dīcere).

Caveō, cavēre, cāvī, cautum

(L) . . . . . . (cūrō, nē malum mihi accidat).

Cēdō, cēdere, cessĩ , cessum (xL) . (discēdō: minus possum quam alius).

Celeber, celebris, celebre (xxvi) . (illūstris: urbs celebris multōs hominēs continet).

Celer, celeris, celere (viri) . . . (rogā magistrum).

Celeritās, celeritātis, $f .(\mathrm{xx})$. . (cf. Celer).

Celeriter (xI). . . . . . (cf. Celer).

Cella, cellae, $f$. (Iv) . . . . . . (in Fōrmulā III).

Cēna, cēnae, $f$. (L) . . . . . (id quod vespere edimus).

Cēnō, cēnāre, cēnāvì, cēnātum

(L) . . . . . . . (cēnam edō).

Cēnseō, cēnsēre, cēnsuī, cēnsum (xLII) . . . . . . (putō: dēcernō: monēô).

Centuriō, centuriōnis, $m$.

(xLVIII) . . . . . (is quī centum mïlitibus praeest).

Cerasus, cerasī, $f .(\mathrm{xxxvi})$. . . (pict. xxxvi).

Certus, certa, certum (xxxıI) . (vērus; quī movērī nōn potest).

Cēterī, cēterae, cētera (xxIII) . . (omnēs reliquĩ).

Charta, chartae, $f$. (xix) . . . . (in Fōrmulā Iv).

Cibus, cibĩ, m. (Ix) . . . . . (id quod edimus).

Circiter (xxIv) . . . . (xxxix vel xxxxii est circiter $\mathrm{xxxx}$ ).

Circum (cum acc.) (Iv) . . . . (in Fōrmulā III).

Circumstō, circumstāe, circumstetī $(\mathbf{L}) \ldots \ldots$. (circum+stō).

Cīvìlis, cīvīle (L) . . . . . . . (quod ad cīvēs pertinet).

Cĩvis, eĩvis, $m$. (xxıv) . . . . (is quĩ in urbe vel in pạtriā habitat). 
Cìvitās, cīvitātis, f. (xuvin) . . (cīvēs omnēs: urbs).

Clāmō, clāmāre, clāmāvī, clāmātum $(\mathrm{xL}) \ldots$. . . . (clāmōrem faciō).

Clāmor, clāmōris, $m$. (xxx) . (magnae vōcēs hominum).

Clārus, clāra, clārum (xLvi) . . (illūstris: facile vīsus).

Classis, classis, $f$. (xvi) . . . . (multī discipulī: multae nāvēs).

Claudō, claudere, clausī, clausum (II) . . . . . . . (rogā magistrum).

Claudus, clauda, claudum (xxxII) . . . . . . (pict. xxxII).

Claustrum, claustrī, $n$. (xxvi) . (id quō aliquid claudimus: iānua).

Clēricus, clēricī, $m$. (xxıv) . . . (pict. Xxıv).

Coepī, coepisse (xxxıv) . . . ( (cf. Incipiō).

Cōgitō, cōgitāre, cōgitāvī, cōgitātum (xxII) . . . . . . (pict. xxxII).

Cognātus, cognāta, cognātum (xxIv) . . . . . (ab eōdem homine ac alius, patre, vel eius patre, vel eius, nātus).

Cognōscō, cognōscere, cognōvì, cognitum (xxıv) . . . . (scīre incipiō).

Cōgō, cōgere, coēgì, coactum (xu) . . . . . (colligō: alicui aliquid necesse faciō).

Cohors, cohortis, $f .(\mathrm{xL})$. . . (multì comitēs vel mīlitēs).

Cohortor, cohortārī, cohortātus sum (xLII) . . . . . . (dictīs persuādēre cōnor).

Colligō, colligere, collēgī, collēetum (xxxiv) . . . . . (in ūnum locum ferō).

Collis, collis, $m$. (xL) . . . . . (parvus mōns).

Collocō, collocāre, collocāvī, collocātum (xL) . . . . . (in ūnum locum ferō).

Colloquium, colloquī, $n$. (xL) . . (sī quĩ colloquuntur, collo-

Colloquor, colloquī, collocūtus quium est). $\operatorname{sum}(\mathrm{xL}) \ldots . . . .($ (cum aliō loquor). 
Colō, colere, colūi, cultum (xviI) . . . . . (amō: labōrō ut ager frūctum ferat).

Comedō, comedere, comēdī, comēsum (xuIv) . . . . . (cum+edō).

Comes, comitis, $m$. (xxxıx) . . (is quĩ cum aliquō it).

Cōmis, cōme (xxıv) . . . . . . (quĩ amīcus est: facit id quod

Comitor, comitārî̀, comitātus dēsīderāmus). sum (XLIX) . . . . . . (comes ēō).

Commeātus, commeātūs, $m$. (xLviII) . . . . . . . (tempus quō īre et redīe quis potest: cibus quem exercitus sēcum portat).

Commemorō, commemorāre, commemorāvī, commemorātum $(\mathrm{XL})$. . . . . . (nārrō).

Commeō, commeāre, commeāvī, commeātum (IX) . . . . (eōinter duo; ad illud, ad học). Committō, committere, commīsī, commissum (xvi) . . . (in manūs dō).

Commodus, commoda, commodum (xLVII). . . . . . (bonus, facilis, amīcus).

Commoveō, commovēre, commōvī, commōtum (xıiI) . . . (rogā magistrum).

Commūnis, commūne $(\mathrm{xL})$. . . (quod aliquī inter sē aequē habent).

Comparō, comparāre, comparāvī, comparātum $(\mathrm{xL})$. . . (in ūnum locum cum alī̄s ferō: utrum melius sit quaerō).

Compleō, complēre, complēvī, complētum $(\mathrm{xL})$. . . . (in rē omnia pōnō quae continēre potest).

Complūrēs, complūra $(\mathrm{xL})$. . (permultī).

Comprehendō, comprehendere, comprehendī, comprehēnsum (xviII) . . . . . (capiō). 
Concēdō, concēdere, concessī, concessum (xL) . . . . . (faciō quod alius volt: discēdō). Concidō, concidere, concidī $(\mathbf{x x x}\lfloor x)$. . . . . . (cadō).

Concilium, concilī, n. (xLIX). . (multī hominēs in ūnum locum collectī).

Conclāmō, conclāmāre, conclāmāvī, conclāmātum (xviı) . (exclāmō).

Conclūdō, conclūdere, conclūsī, conclūsum (xxx) . . . . . (in aliquō locō claudō).

Condīciō, condīciōnis, $f$. (xlv) . (sī aquam mihi dabis, nummum tibi dabō: sī nōn dabis, tibi nōn dabō: haec est condīciō).

Cōnferō, cōnferre, contulī, collātum (xL) . . . . . . (cum aliō ferō).

Cōnfertus, cōnferta, cōnfertum $(\mathrm{XL})$

- (sī multī in parvō locō sunt, cōnfertī sunt).

Cōnfíciō, cōnficere, cōnfēcī, cōnfectum (xxxıv) . . . . . (omnīnō faciō: dēleō).

Cōnfĩdō, cōnfīdere, cōnfīsus sum (xvi) . . . . . (sī tibi cōnfīdō, putō tē vērum dìcere).

Cōnfirmō, cōnfirmāre, cōnfirmāvì, cōnfirmātum (xxı) .(dīcō vērum esse). Cōnfodiō, cōnfodere, cōnfōdī, cōnfossum (L) . . . . . (aliquem mūcrōne cultrī vehementer feriō).

Congerō, congerere, congessī, congestum (xxxiv) . . . . (tumulum faciō).

Coniciō, conicere, coniēeī, coniectum $(\mathbf{x L})$. . . . . . (in ūnum locum iaciō).

Coniungō, coniungere, coniūnxī, coniūnctum (xxıv) . . (ünum ex plūribus faciō).

Coniūnx, coniugis, $m$. vel $f$. (xxıv) ....... (uxor: vir quī uxōrem habet). 
Coniūrō, coniūrāre, coniūrāvĩ, coniūrātum (L) . . . . (cum alī̄s malum cōnsilium capiō).

Cōnor, cōnārī, cōnātus sum (xxxvi) . . . . (aliquid facere volō: labōrō, et fortasse faciam).

Cōnscrībō, cōnscrībere, cōnscrīpsī, cōnscrīptum (xLviI) . (scrībō: alia cum alī̄s scrībō).

Cōnsentiō, cōnsentīre, ' cōnsēnsī, cōnsēnsum (L) . . . . . (idem putō vel sentiō).

Cōnsequor, cōnsequĩ, cōnsecūtus sum $(\mathrm{xL})$. . . . . (cum aliīs sequor).

Cōnservō, cōnservāre, conservāvī, cōnservātum (xL) . . . (servō).

Cōnsīdō, cōnsīdere, cōnsēdī, cōnsessum (xI) . . . . . (contrārium est Surgō).

Cōnsilium, cōnsilī, $n$. (xxxıv) . (sapiēns homō cōnsilium habet, et cōnsilium dat).

Cōnsistō, cōnsistere, constitī, cōnstitum (xvII) . . . . (mē nōn commoveō).

Cōnspiciō, cōnspicere, cōnspexī, cōnspectum (xxI) . . . . . (videō: spectō).

Cōnstituō, cōnstituere, cōnstituī, cōnstitūtum (xxxıv) ‥ (certum faciō: mihi dīcō "Hoc faciam").

Cōnsuēscō, cōnsuēscere, cōnsuēvī, cōnsuētum (xxxıv) . . (saepe faciō).

Cōnsuētūdō, cōnsuētūdinis, $f$. (xxxvi) . . . . (sĩ cōnsuēscō, consuc̄tūdō c.st mihi).

Cōnsul, cōnsulis, $m$. (xLIx) ‥(ūnus ex duōbus quī u:ìcin

Contendō, contendere, conRōmam regēbant). tendī, contentum (xxxix) . . (labōrō: properō: pugnō).

Contineō, continēre, continuī, contentum (xv) . . . . (in mē tenēo).

Contrā (cum .acc.) (Iv) . . . . (in Fōrmulā III). 
Contumēlia, contumēliae, $f$. (xxxix) ....... (id quod malō animō contrā aliquem dīcitur).

Conveniō, convenīre, convēnī, conventum (xxiv) . . . (in eundem locum cum aliis veniō).

Convertō, convertere, convertī, conversum (xxiv) .... (rogā magistrum).

Cōpia, cōpiae, $f .(\mathrm{xL}) \ldots \ldots$ (multum).

Cōpiae, cōpiārum, f. (xLvi) . . (multitūdō mīlitum).

Corbis, corbis, $m$. (xıI) . . . . (pict. xilI).

Cornū, cornūs, $n$. (xxv) . . . . (pict. xxıII: pars aciēī vel sinistra vel dextra).

Cornūtus, cornūta, cornūtum (xxv) ........ (quod cornua habet).

Corpus, corporis, $n$. (xLviII) . . (tōtus homō vel animal, animō exceptō: tōtus homō quem vidēre vel tangere possumus).

Corripiō, corripere, corripuī, correptum (xxI) . . . . (rapiō).

Cottīdiānus, cottĩdiāna, cottīdiānum (xL) ...... (ef. Cottīdiē).

Cottīdiē $(\mathrm{xL}) \ldots \ldots$. . (ūnō quōque diē).

Cräs $(\mathrm{xxxI}) \ldots . .$. (diē post hodiernum diem).

Crēdō, crēdere, crēdidì, crēditum (vi) . . . . . . . . (cf. Dīcō in Pēnsō vi).

Cremō, cremāre, cremāvì, cremātum (xxxıx) . . . . . (ignī dēleō).

Crēscō, crēscere, crēvī, crētum (xxir) . . . . . . . (in diēs maior sum).

Crēta, crētae, f. (III) . . . . (crētā in pariete scrībimus).

Cruciō, cruciāre, cruciāvī, cruciātum (L) . . . . . . (cruce necō).

Crūdēlis, crūdēle (xxıır) . . . . (quī nōn meritō male facit invalidō).

Crux, crucis, f. (L) . . . . (rogā magistrum). 
Cubō, cubāre, cubuī, cubitum

$(\mathrm{xxx})$. . . . . . . (in lectulō dormiō: iacēō).

Cucullus, cucullī, m. (xI) . . (pict. XI).

Culter, cultrī, m. (xxi)... (pict. $\mathrm{xxI})$.

Cum (cum abl.) (xıx) . . . . (rogā magistrum).

Cum (xlv) . . . . . . . . (in Fōrmulā viı).

Cunctus, cuncta, cunctum $(\mathrm{xxx})$. . . . . . . (omnis).

Cupidus, cupida, cupidum (XL) . (maximē volēns).

Cupiō, cupere, cupīvī, cupītum

(xliv) . . . . . . . . (dēsīderō).

Cūr (xıI) . . . . . . (quaestiō cui respōnsum est "Proptereā quod").

Cūra, cūrae, $f$. (xvi) . . . . (tibi bonum dēsīderō, et labōrō: cūrae tū es mihi).

Cūrātor, cūrātōris, m. (xviII) . . (is cui aliquid cūrae est).

Cūrō, cūrāre, cūrāvī, cūrātum

(xxıx) . . . . . . (alicui bonum dēsīderō, et labōrō).

Currō, currere, cucurrī, cursum (xv) . . . . . . . (celeriter pedibus cō).

Currus, currūs, $m$. (xxxıx) . . (pict. Xlvi).

Cūstōdiō, cūstōdīre, cūstōdīvī, cūstōditum (xLIX) . . . . (perīculum prohibeō).

D

Dè (cum abl.) (xıx). . . . (rogā magistrum).

Dea, deae, $f$. (xLVI) . . . . . (cf. Deus: Rōmānī multōs deōs et deās colēbant).

Dēbeō, dēbēre, dēbuî, dēbitum

(xxxıI) . . . . . . (necesse est mihi aliquid reddere, proptereā quod aliquid accēpī).

$\operatorname{Decem}(\mathrm{Ix})$. . . . . . (numerus . . . X).

Dēcernō, dēcernere, dēcrēvī, dēcrētum (xL) . . . . . (cōnsilium mihi capiō). 
Decet, decēre, decuit (xxıv) . . (rogā magistrum).

Dēeīdō, dēcīdere, dēcīdī, dēcīsum (xxI) . . . . . . (pict. xxxvi).

Decimus, decima, decimum (xlvi). . . . . . (cf. Decem: ef. quoque Prïmus,

Dēclārō, dēelārāre, dēelārāvī, et e.). dēclārātum (xxıv) . . . . . (cōnfirmō).

Dēdō, dēdere, dēdidī, dēditum (XLviII)

Dēdūcō, dēdūeere, dēdūxī, dēductum (xxiv) . . . . . (dūeō).

Dēfendō, dēfendere, dēfendī, dēfēnsum (xxxiv) . . . . (servō: ef. Servātor).

Dēferō, dēferre, dētulī, dēlā$\operatorname{tum}(\mathrm{xL})$. . . . . . . . (dē+ferō: dō: nūntiō).

Dēiciō, dēicere, dēiēcī, dēiectum $(\operatorname{xxx} 1 \mathrm{x}) . . . . .(\mathrm{de}+\mathrm{e}$. . . . .

Deinde (XL) . . . . . . (posthāc).

Dēleō, dēlēre, dēlēvī, dēlētum (xxxII)

(sī librum in ignem iaciō, librum dēleō: sī litterās abstergēō, dēleō).

Dēliciae, dēliciārum, $f$. (xuIx) . (id quō gaudēmus: illa quā gaudet aliquis).

Dēligō, dēligere, dēlēgī, dēlēctum (xL) . . . . . . (ex multīs capiō quod mihi optimum vidētur).

Dēmergō, dēmergere, dēmersī, dēmersum (xxxiI) . . . . (sub aquam agō).

Dēmōnstrō, dēmōnstrāre, dēmōnstrāvī, dēmōnstrātum (xxv) . . . . . . (doceō, indiē̄).

Dēscendō, dēscendere, dēscendī, dēseēnsum (xxI) . . . (contrārium est Ascendō).

Dēserō, dēserere, dēseruī, dēsertum (xlviıI) . . . . (relinquō). 
Dēsīderō, dēsīderāre, dēsīderāvĩ, dēsīderātum $(\mathbf{x v})$. . . (nōn habeō: sĩ habēbō, gaudēbō).

Dēsistō, dēsistere, dēstitī, dēstitum $(\mathrm{xL}) \ldots$. . . . (faciēbam, sed nōn iam faciō).

Dēstringō, dēstringere, dēstrīnxī, dēstrictum (xxI) . . (pict. xxI).

Dēsum, dēesse, dēfuī (xuII) . . (absum: nōn sum).

Dētrahō, dētrahere, dētrāxī, dētractum (xLviII) . . . . (ex locō eapiō).

Deus, deī, $m$. (xxıv) . . . . . (Is quī omnia regit).

Dexter, dextra, dextrum (xxi) . (rogā magistrum).

Dìcō, dīeere, dīxī, dictum (VI) . . (quaestiō in Pēnsō vi).

Diês, diēì, m. (Ix) . . . . . (xxiv hōrae: Surgimus, labōrāmus, lūdimus, dormīmus; inter "Surgimus" et "Dormīmus" est diēs).

Difficultās, difficultātis, $f$. (xL) . (difficultās est mihi sĩ quid vix facere possum).

Digitus, digitī, m. (III). . . . . (in Fōrmulā II).

Dīligenter (xviır) . . . . . . (magnā cum cūrā).

Dỉligentia, dïligentiae, $f$. (xxvi) . (eūra: cf. Dïligenter).

Dỉligō, dīligere, dìlēxī, dīlēetum (xxrv). . . . . . . (amō).

Dìmidium, dīmidī, $n$. (Ix) . . . (dīmidium+dīmidium e s t Ūnus).

Dïmittō, dīmittere, dīmīsī, dīmissum (xxxir). . . . . (ā mē mittō).

Discēdō, discēdere, discessī, discessum (xvir) . . . . . (abeō).

Discipula, discipulae, $f$. (xiri) . . (puella quae ad lūdum it).

Discipulus, discipulī, m. (xIII) . (puer quī ad lūdum it).

Diseō, diseere, didicī (xxıI) . . (ēdiscō).

Diū (xxiv) . . . . (per longum tempus).

Dīves, dīves (xviıI) . . . . (dīvitēs sunt illī quĩ multa possident).

Dō, dare, dedī, datum (xi) . . (rogā magistrum). 
Doceō, docēre, docuī, doctum $(\mathrm{xxI})$

(magister sum, in lūdō dīcō et discipulī diseunt).

Doleō, dolēre, dolū̄, dolitum (xı). (contrārium est Gaudeō).

Dolor, dolōris, m. (xvi) . . . . (sī doleō, dolor est mihi).

Domesticus, domestica, domes-

ticum (xxıv) . . . . (quod in domō est, vel in domō facimus).

Domicilium, domicilī, $n$. (xxxvi) . . . . . . (domus).

Domina, dominae, $f$. (xxiri) . . (ea quae hominem vel animal possidet, vel regit).

Dominus, dominī, m. (xvıII) . . (is quī hominem vel animal possidet, vel regit).

Domus, domūs, $f$. (xxıv) . . . (aedēs, vīlla, in quā habitāmıs). Dormiō, dormīre, dormīvī, dormītum (Ix) . . . . . . (rogā magistrum).

Dubitō, dubitāre, dubitāvī, dubitātum (xxxıv) . . . . (nōn certō sciō).

Dūcō,dūcere, dūxī,ductum(xi1I). (sī tē dūcō, mēeum vel post mēe venīs: sī puellam uxōrem dūeō, illam uxōrem faciō).

Dulcēdō, dulcēdinis, $f$. (xv) . . (cf. Duleis).

Dulcis, dulce (xv) . . . (sī quid dulce edimus, gaudēmus).

Duo, duae, duo (Ix) . . . . (numerus ... II).

Duodecim (IX) . . . . . (numerus ... XII).

Duodecimus, duodecima, duo-

decimum (xlviII) . . . . (cf. Duodecim: ef. quoque Prīmus, et c.).

Dux, ducis, m. (xxıv) . . . . (is quī dūcit).

$\mathbf{E}$

$\overline{\mathrm{E}}$ vel Ex (xıx) . . . . . . (in Fōrmulā Iv).

Ecclēsia, ecelēsiae, $f$. (xxıv) . . (piet. xxıv).

Ėdiscō, ēdiscere, èdidiē (Ix) . . (legō et legō: sciō: iam ēdidicī). 
Edō, edere, ēdī, ēsum (Ix) . . . (aquam bibō, sed cibum edō). Efficiō, efficere, effēcī, effectum (xxıv) . . . . . . (faciō).

Effigiēs, effigiēì, $f$. (ıII) . . . (in Fōrmulā ıI).

Effugiō, effugere, effūgī (xxıv) . (mē līberō).

Ego, meī (v) . . . . . . . . ( . . (ego) feriō, (tū) ferīs, et c.)

Ëgredior, ēgredī, ēgressus sum (xliI) . . . . . . . (exeō: ex aliquō locō ambulō). Ēheu (xııI) . . . . . . . ("Ēheu" dīcō sī doleō).

Ėlābor, ēlābì, èlāpsus sum (xxxıv) . . . . . . (excidō).

Enim (xxıv) . . . . . . (proptereā quod).

Ēnumerō, ēnumerāre, ēnumerāvī, ēnumerātum (xviıI) . . (rogā magistrum).

Eō, īre, ì̄, itum (Iv) . . . . . . (in Fōrmulā III).

Eques, equitis, m. (xLIII) . . . (is quī in equō it).

Equitātus, equitātūs, m. (xLvi) . (pict. Xlvi).

Equus, equī, m. (xxII) . . . . (pict. XLVI).

Ergō (xxxıI) . . . . . . . (itaque).

Ērigō, ērigere, ērēxī, ērēetum (II) . . . . . . . . . (in Fōrmulā II).

Ēripiō, ēripere, ēripuī, ēreptum (xliI) . . . . . . . . (ex aliquō rapiō).

Errātiō, errātiōnis, f. (xLII) . . . (sī errō, errātiō est).

Errō, errāre, errāvī, errātum (xxıv). . . . . . . . (in omnēs partēs eō).

Ēruditus, ērudita, ērudītum (xxıv). . . . . . . (quī multa didicit, multa scit). Esuriō, ēsurīre, 一, ēsurītum (xxiII) . . . . . . (cibum dēsīderō).

Etiam (xxvi). . . . . . (rē vērā: quoque).

Êveniō, ēvenīre, ēvēnī, ēventum (xlviII) . . . . . . ( $\overline{\mathrm{e}}+$ veniōo $)$.

Ẽvigilō, ēvigilāre, ' èvigilāvī, ēvigilātum (xxxıv) . . . . . (nōn iam dormiō).

Excēdō, excēdere, excessī, excessum (xxix) . . . . (ex+cēdō: cf. Discēdō). 
Excidō, excidere, excidī (xxIv) . (ex aliquō cadō).

Excipiō, excipere, excēpī, exceptum (xxI). . . . . . (mihi capiō: ex+capiō).

Exclāmō, exclāmāre, exclāmāvī, exclāmātum (xv) . . . (magnā vōce dīcō).

Exemplum, exemplī, $n$. (xlviI) . (ūna rēs ex tōtō genere).

Exeō, exīre, exī̄, exitum

$(\mathrm{xxxix}) \ldots \ldots(\mathrm{ex}+\mathrm{e} \overline{\mathrm{o}})$.

Exercitus, exercitūs, $m$. (xxıv) . (multī mīlitēs).

Exhibeō, exhibēre, exhibūi, exhibitum (xxxvı) . . . . (habeō, et alicui dō et vidēre permittō).

Exinde (xxxix). . . . . . (post hoc).

Exīstimō, exīstimāre, exīstimāvī, exīstimātum (xuıI) . . . (putō).

Exitium, exitī, $n$. (xxvi) . . . . (mors).

Expellō, expellere, expulī, expulsum (xxxiI) . . . . . (ex locō agō).

Experior, experīī, expertus sum (XLviI) . . . . . (nōn sciō an rēs bona sit: aliquid faciō ut discam).

Explānō, explānāre, explānāvī, explānātum (xuvıI) . . . . (explicō: doceō ut intellegās).

Exquīrō, exquīrere, exquīsīvī, exquisistum (xLI) . . . . . (quaerō).

Exsiliō, exsilīre, exsilū̄ (xv) . . (piet. xv).

Exspectō, exspectāre, exspeetāvì, exspectātum (xi) . . . (stō et putō "Mox vidēbō").

\section{F}

Faba, fabae, $f .($ xxI $) \ldots . . .($ piet. XxI).

Fabālis, fabāle (xxı) . . . . (quod fabās habet).

Fābula, fābulae, f. (x) . . . . . (rogā magistrum).

Faciēs, faciēī, $f$. (xıII) . . . . (rogā magistrum).

Facilis, facile (xxix) . . . (quod facere possumus). 
Facinus, facinoris, $n$. (xLII) . . (id quod facimus: malum quod facimus).

Faciō, facere, fēcī, factum (I) . . (quaestiō in Pēnsō I).

Falsus, falsa, falsum (xxxıv) . . (contrārium est Vērus).

Famēs, famis, $f$. (xxxvi) . . . . (sī ēsuriō, famēs est mihi).

Familiāris, familiāre (xlviı) . . (domesticus: amīcus).

Fātum, fātī, $n$. (xxxiv) . . . (id quod deus nōbīs dedit, vel fēcit).

Fatuus, fatua, fatuum (xv) . . (stupidus).

Faucēs, faucium, $f .(\mathrm{xx})$. . . (animal in faucibus cibum tenet).

Favēo, favēre, fāvī, fautum (xvi) ........ (sī tibi faveō, faciō id quod dēsīderās).

Fēlēs, fēlis, $f .(\mathrm{xxx}$. . . . . (pict. xxxıI).

Fèlixx, fēlīx (xxıv). . . . (fēlìcem appellāmus eum quī bona habet, maximē sī nōn exspec!at).

Fēmina, fēminae, $f$. (xxıx) . . . (mulier).

Fenestra, fenestrae, $f$. (III) . . (rogā magistrum).

Ferē (xxvı) . . . . . . (xxxix est ferē xxxx).

Fēriae, fēriārum, $f$. (Ix) . . . . (diēs ubi ad lūdum nōn ìmus).

Feriō, ferīre, percussī, percus-

sum (I) . . . . . . (in Fōrmulā I).

Ferō, ferre, tulī, lātum (xv) . . (portō: sī rem ferō, mē nōn opprimit).

Fertilitās, fertilitātis, $f_{.}(\mathrm{xv})$. . (contrārium est Sterilitās).

Ferus, fera, ferum (xxvi) . . . (contrārium.est Domesticus vel Mānsuētus).

Festīnō, festīnāre, festīnāvī,

$$
\text { festīnātum (xxi) . . . . . (properō). }
$$

Fidēlis, fidēle (xxıv) . . . . (cui cōnfīdere possumus).

Fidēs, fideī, $f$. (xıviıi) . . . . . (sī cōnfīdō, fidem habeō).

Fìlia, fîliae, $f$. (xvin) . . . . (puella quae patrem vel mātrem habet).

Fīlius, fīlī, m. (xvıı). . . . (puer quĩ patrem vel mātrem habet). 
Fīniō, fīnīre, fīnīvĩ, fīnītum (L) . (fīnem faciō).

Fīnis, fīnis, m. (xxıv) . . . . (ultima pars).

Fīnitimus, fīnitima, fīnitimum

(xlviì) . . . . . . (prope ab aliquō habitāns).

Fìō, fierī, factus sum (xxix) . . (sī rem faciō, ea rēs fit).

Flagellō, flagellāre, flagellāvī,

flagellātum (xxx) . . . . (plāgās īnflīgō).

Flagrō, flagrāre, flagrāvī, fla-

grātum (xvir) . . . . . (sī in ignibus sum, flagrō).

Flamma, flammae, $f$. (xvir) . . (ignēs).

Flōs, flōris, m. (xxxıv) . . . . (pict. XıII).

Flümen, flūminis, $n$. (xxxıI) . . (pict. xxıII).

Fluō, fluere, flūxī, flūxum

(xxxıx) . . . . . . (sī flūmen currit, dìcimus "Fluit").

Focus, focī, m. (xLIX) . . . . (pict. XXIV).

Fōns, fontis, m. (xuII) . . . . (locus in terrāē quōaqua venit).

Forēs, forum, f. (xxiv) . . . (pict. xxıv).

Fortasse (xxIv). . . . . (potest esse).

Fortis, forte (xvII) . . . . . (quī nōn timet).

Fortitūdō, fortitūdinis, $f$. (xvII) . (cf. Fortis).

Fortūna, fortūnae, $f$. (xlviıI) . . (id quod nōbīs accidit).

Frāter, frātris, $m$. (xxxıv) . . . (fīlius eiusdem patris).

Frequentō, frequentāre, fre-

quentāvī, frequentātum (xıI) . (saepe eō vel veniō).

Frīgeō, frīgēre $(\mathrm{xxx} ı \mathrm{x})$. . . (contrārium est Caleō).

Frōns, frondis, $f$. (xxxıv) . . . (pict. XIII).

Frūctus, frūctūs, $m$ : (xIII) . . (pict. XIII).

Frūmentum, frūmentī $n$. (xxvi) . (cibus quem bovēs (et hominēs) edunt).

Fuga, fugae, f. (xuII) . . . . (sī quis fugit, fugam capit).

Fugiō, fugere, fūgī, fugitum (xxxvi). (ab aliquō currō).

Fulmen, fulminis, $n$. (xxxıx) . . (ignis quem Iuppiter dē caelō iacit).

Fundus, fundī, $m$. (xıII) . . . (pict. xiII).

Furor, furōris, m. (xxxviII) . . (îra). 


\section{G}

Gaudeō, gaudēre, gavīsus sum

(xI). . . . . . . . (rogā magistrum).

Gaudium, gaudī, $n .(\mathrm{xx} \mathbf{x})$. . . (sī gaudē, gaudium est mihi).

Gēns, gentis, $f$. (xxıv) . . . (multī hominēs, quī omnēs cognātī sunt).

Genū, genūs, $n$. (xxv) . . . . (in Fōrmulīs Neutrī Generis). Genus, generis, n. (xxvi) . . . ("masc., fem., neu.": "Cuius generis" est "quālis").

Gerō, gerere, gessī, gestum (xxıv) . . . . . . (faciō).

Gigās, gigantis, $m .(\mathrm{xxI})$. . . (pict. XxI).

Gladius, gladī, $m$. (xLVII) . . . (longus "culter" quem imperātor in proeliō habet).

Glāns, glandis, f. (xxxıv) . . . (pict. xxxvi).

Glōrior, glōriārī, glōriātus sum (xxxıx) . . . . . . . (mē iactō $)$.

Gradus, gradūs, m. (IX) . . . (rogā magistrum).

Graecē (L) . . . . . . . . (linguā Graecōrum).

Grammaticus, grammatica, grammaticum (Ix) . . . . (rogā magistrum).

Grātia, grātiae,f. (xvırI) . . . (bonum quod alicui dāmus: "Grātiās agō" dīcimus sī quis bonum nōbīs facit).

Gravis, grave (vıII) . . . . (rogā magistrum).

Gravitās, gravitātis, f. (x). . . (cf. Gravis).

Gustō, gustāre, gustāvī, gustātum (xxxvr)...... (edere incipiō).

\section{H}

Habeō, habëre, habuī, habitum (Ix) . . . . . . . (teneō: meum est). Habitō, habitāre, habitāvī, habitātum (xxıv). . . . (ubi mea vīlla est, habitō). 
Haruspex, haruspicis, m. (L) . . (homō quī dīcit quae posthāc futūra sint).

Hasta, hastae, f. (xLIX) . . . (pict. XLVI).

Herba, herbae, $f$. (xIII) . . . (pict. XIII).

Heri (xxviI) . . . . . (diē ante hodiernum diem).

Heus (xvir) . . . . . . (attende: attendite).

Hiātus, hiātūs, m. (xuII) . . (locus apertus inter duās rēs).

Hic, haec, hoc (v) . . . . (cf. Ille: rogā magistrum).

Hīc (xvir) . . . . . . . (hōe locō).

Hiems, hiemis, $f$. (xLII) . . . (pars annī ubi omnia frīgent).

Hinc (xxıx) . . . . . . (ab hōc).

Hodiē (xxviı) . . . . . (hōe diē).

Hodiernus, hodierna, hodiernum (xxviI) . . . . . . (cf. Hodiē).

Homō, hominis, $m$. vel $f$. (xI) . . (puer: puella: anus: contrārium est Animal).

Honestus, honesta, honestum

(xxiv). . . . . . (quem omnēs bonum esse putant).

Hōra, hōrae, f. (Ix) . . . . . (rogā magistrum).

Horribilis, horribile (xxI) . . (terribilis).

Hortus, hortī, m. (xv) . . . . (pict. xv).

Hospes, hospitis, m. (L) . . . (amīcus, quī domī meae est vel cuius domī sum).

Hostis, hostis, m. (xxIv). . . . (is quī contrā patriam pugnat). Hūe (xxx). . . . . . . (ad hunc locum).

Hūmānus, hūmāna, hūmānum

(xxvi). . . . . . . (cf. Homō).

Humilis, humile (vir) . . . . (contrārium est Altus).

Hymenaeus, hymenaea, hymenaeum (xxıv) . . . . (ubi vir uxōrem dūcit, diēs hymenaeus est).

\section{I}

Ibi (xxxıv) . . . . . . . (in eō locō).

Ietus, ietūs, m. (xLII) . . . . (plāga).

İdem, earlem, idem (xxı) . . . (rogã magistrum). 
Idōneus, idōnea, idōneum

(xviII) . . . . . . (laus est bonō puerō idōnea: malō puerō plāgae).

Īdūs, Īduum, f. (L) . . . . . . (quōrundam mēnsium diēs xiii $^{\text {us }}$, quōrundam diēs $\mathrm{xv}^{\mathrm{us}}$ ).

Igitur (xv). . . . . . . (itaque).

Ignis, ignis, m. (xvII) . . . . (pict. XvII).

Ignōrō, ignōrāre, ignōrāvī, ignōrātum (xxxıx) . . . . . (nōn sciō).

Ignōscō, ignōscere, ignōvī, ignōtum (xvI) . . . . . . (sī cui male facis, et nōn voluistī, dīcis illī "Ignōsce mihi ").

Ignōtus, ignōta, ignōtum (xxvı). (nōn cognitus: ef. Cognōscō).

Ille, illa, illud (v) . . . . . (cf. Hic: rogā magistrum).

Illūe (xxI) . . . . . . . (ad illum locum).

Illūstris, illūstre (xxıv) . . . (bonus et magnus).

Imāgōo, imāginis, $f .(\mathrm{L})$. . . . (effigiēs).

Immineō, imminēre (xvi) . . . (in Fōrmulā IV).

Impedīmentum, impedīmentī,

n. (xLVI). . . . . . . . (id quod impedit: pict. XLVI).

Impediō, impedīre, impedīī̄, impedītum (xxxıx) . . . (nōlō tē aliquid facere: itaque in viä stō).

Imperātor, imperātōris, $m$. (xVII) . . . . . . . . (is quĩ imperat: pict. XVII).

Imperium, imperī, n. (xLVI) . . (sī imperō, imperium habeō). Imperō, imperāre, imperāvī, imperātum (xvi). . . . . . (dīcō "Fac hoc").

Impetus, impetūs, m. (xLVI) . . (sī hostēs adorior, in eōs impe-

Impōnō, impōnere, imposuī, tum faciō). impositum (xvi) . . . . . (in Fōrmulā IV).

Importō, importāre, importāvī, importātum (xxxıI). . . . (in+portō).

İmus, ima, ìmum (xxxvi) . . . (īnferus, inferior, infimus vel imus).

In (cum acc.) (IV) . . . . . (in Fōrmulā III). 
In (cum abl.) (xıx) . . . . . . (in Fōrmulā IV).

Incendō, incendere, incendī, incēnsum (xxxıx). . . . . (in aliquō flammam faciō).

Incipiō, incipere, coepī, coeptum (xıII) . . . . . . (initium faciō).

Incognitus, incognita, incognitum (xxi) . . . . . . . . (quod nōn ante vīdī nec audīīi).

Incolō, incolere, incoluī (xxıv) . (habitō).

Incompositus, incomposita, incompositum (xxıv) . . . . (mixtus: ef. Misceō).

Incrēdibilis, incrēdibile (xLII) . . (quod crēdere nōn possumus). Indicium, indicī, $n$. (xxxıv) . . (id quod indicat).

Indicō, indicāre, indicāvī, indicātum (XXII) . . . . . . . . (rogā magistrum).

Induō, induere, induī, indūtum

. (in Fōrmulā I).

Ineō, inīre, inī̄, initum (xxI) . . (in+ēô).

Ineptus, inepta, ineptum (xxiv). (fatuus).

Înfēlīx, infēlīx (xiI) . . . . (īnfēlīeēs, sī bona exspectant, mala habent).

Înferior, inferius (xxx) . . . (contrārium est Superior).

İnferus, infera, inferum (xLIX) . (quī īnfrā est).

Înfligōo, īnflīgere, înflīxī, īnflìctum (xvi) . . . . . (in Fōrmulā IV).

$\overline{\operatorname{Infrā}}(\mathrm{xxx})$. . . . . . . (sub aliquō).

Ingemō, ingercere, ingemuī (L) . (dolōrem vōce indicō).

Iniciō, inicere, iniēcī, iniectum

(xVII) . . . . . . . (pict. XVII).

Inimīcus, inimīca, inimīcum

(xxi) . . . . . . (nōn amīcus).

Initium, initī, $n$. (xıII) . . . . (prīma pars eius quod facimus).

Iniūria, iniūriae, $f$. (xlviıi) . . . (malum quod contrā iūs fit).

Innumerus, innumera, innumerum (xviil) . . . . . (quod ēnumerāre nōn possumus).

Inquam, inquis, inquit (xxI) . . (dīcō).

Insistō, însistere, īnstitī (xLviII). (super vel in aliquō stō). 
Înspiciō, înspicere, inspexī, innspectum (xxvi). . . . (spectō).

İnstituō, īnstituere, instituī, institūtum (xLvI) . . . . (faciō: cōnstituō: doceō).

İnstrūmentum, ìnstrūmentī, $n$. $(\mathrm{xx}) \ldots \ldots$. . . . (quaestiō in Pēnsō $\mathrm{xx}$ ).

Înstruō, instruere, instrūxĩ, instrūctum (xLVI) . . . (parō).

Insula, insulae, $f .(\mathrm{xL}) \ldots . .($ pict. $\mathrm{xvII})$.

Integer, integra, integrum (xLVIII) . . . . . . (nōn mūtātus: bonus).

Intellegō, intellegere, intellēxī, intellēctum (XIII) . . . . (sciō quid significet).

Intendō, intendere, intendī, intentum (II) . . . . . . (in Fōrmulā II).

Inter (cum acc.) (Iv) . . . . (in Fōrmulā III).

Intereā (xuII) . . . . . (interim).

Interficiō, interficere, interfēcī, interfectum $(\mathrm{xI}) \ldots .$. (pict. $\mathrm{xI})$.

Interim (xLII) . . . . . (inter duo tempora).

Intermittō, intermittere, intermīsīi, intermissum (xLII) . . (ab aliquō dēsistō).

Intrā (cum acc.) (xxxiv) . . . (in).

Intrō, intrāre, intrāvī, intrātum (xxvi). . . . . . (in locum ēo).

Inveniō, invenīre, invēnī, inventum $(\mathrm{xI}) \ldots \ldots$ (veniō ad rem quam nōn exspectāvī).

Invitus, invīta, invitum (xLIV) . (nōlēns).

Ipse, ipsa, ipsum (xxıv) . . . (rogā magistrum).

İra, īrae, $f .(\mathrm{xv}) \ldots \ldots$. . (rogā magistrum).

İrāscor, îrāscī, îrātus sum(xLIx) . (îra est mihi).

Is, ea, id (v) . . . . . . . (cf. Ille: rogā magistrum).

Itaque (xv) . . . . . (post hoc et propter hoc).

Item (xxviII) . . . . . . (eōdem modō).

Iter, itineris, $n$. (xxvi) . . . (via in quā ìmus).

Iterum (xviI) . . . . (rogā magistrum). 


\section{I cōnsonāns}

Iaceō, iacēre, iacuī (xxII) . . . (rogā magistrum).

Iaciō, iacere, iēcī, iactum (xıx) . (cf. Iniciō).

Iactō, iactāre, iactāvī, iactā-

tum $(\operatorname{xxx} \mathbf{x})$. . . . . . (saepe iaciō: "Mē iactō," mē illūstrem esse dīcō).

$\operatorname{Iam}($ XxiIr) . . . . . . (nunc).

Iānua, iānuae, $f$. (III) . . . . . (rogā magistrum).

Iēiūnus, iēiūna, iēiūnum (xv) . . (quī cibum dēsīderat).

Ientāculum, ientāculī, $n$.

(xxxvi) . . . . . . (id quod māne edimus).

Iocus, iocī, m. (xxxiI) . . . . (rogā magistrum).

Iubeō, iubēre, iussī, iussum (xviII). . . . . . . . (imperō).

Iugulō, iugulāre, iugulāvī, iugulātum (L) . . . . . . . (iugulum caedō).

Iugulum, iugulī, $f$. (L) . . . . . (rogā magistrum).

Iūrō, iūrāre, iūrāvī, iūrātum

(xxxIx) . . . . . (ad deum manum porrigō, et dīcō).

Iūs, iūris, n. (xxx) . . . . . (pict. xxıII).

Iūs, iūris, $n$. (xLv) . . . . (id quod bonum et rēctum est). Iussū (xxi) . . . . . . . ("meō iussū" : proptereā quod iubeō).

Iūstus, iūsta, iūstum (xLv) . . . (quī amat id quod bonum et rēctum est).

Iuvenis, iuvenis, m. (xxI) . . . (contrārium est Senex).

Iuvō, iuvāre, iūvī, iūtum (xLII) . (auxilium ferō).

Labefaciō, labefacere, labefēcī, labefactum (xLIII) . . . . (aliquid faciō ut rēs cadat).

Labor, labōris, $m$. (xLVi) . . . . (sī labōrō, labōrem capiō).

Labōrō, labōrāre, labōrāvī, labōrātum (Ix) . . . . . (rem magnam et gravem faciō). 
Lacertus, lacertī, $m$. (xv) . . (pict. xv).

Lacrima, lacrimae, f. (xxıv) . . (id quod dē oculō cadit ubi lacrimāmus).

Lacrimō, lacrimāre, lacrimāvī, lacrimātum (xv) . . . . (doleō: aqua dē oculīs it).

Lactus, laeta, laetum (xxiv) . . (quī gaudet).

Lanius, lan̄i, m. (xxiı) . . . . (pict. xxıII).

Lassitūdō, lassitūdinis, $f$.

(xxxıv) . . . . . . (sī nimis labōrō, lassitūclō mē opprimit).

Latīnē (xi) . . . . . . (latīnē, nōn anglicē, dīcimus).

Latīnus, latīna, latīnum (xxx) . (cf. Latīnē).

Lātrō, lātrāre, lātrāvī, lātrā-

tum (xxıir) . . . . . . (ubi canis aliquid dīcit, lātrat).

Lātus, lāta, lātum (viII) . . . . (rogā magistrum).

Latus, lateris, $n$. (xxxıI) . . (rogā magistrum).

Laus, laudis, $f$. (xvir) . . . . . (sī bonum facis, et dīcō "Bonus es: bene facis," tibi laudem tribuō).

Lēctiō, lēctiōnis, $f$. (xıII) . . . . (id quod legimus: pēnsum).

Lectulus, lectuli, $m$. (xxI) . . . (pict. xI).

Lēgātiō, lēgātiōnis, $f$. (xlvi) . . (lēgātĩ: eĩ quī nūntium ferunt). Lēgātus, lēgātî, $m$. (xLvi) . . . (is quī sub imperātōre mīlitibus imperat).

Legiō, legiōnis, $f .(\mathrm{xLVI})$. . . . (pars exercitūs: circiter sex mīlia mīlitum).

Legō, legere, lēgī, lēctum (Ix) . (rogā magistrum).

Lentus, lenta, lentum (viII) . . (contrārium est Celer).

Levis, leve (viII) . . . . . (contrārium est Gravis).

Lēx, lēgis, $f$. (xuIx) . . . . (id quod dēcrētum est, quō regimur).

Libenter (xxrx) . . . . . (cum gaudiō).

Liber, librī, m. (III) . . . . . . (rogā magistrum).

Lỉber, lībera, lỉberum (xLII) . . (quĩ lỉbertātem habet).

Līberī, līberōrum, $m$. et $f$. (xxx) . (fīliī et fīliae).

Līberō, līberāre, līberāvī, lībe-

rātum (xxıv) . . . . (contrārium est Revinciō). 
Lībertās, lībertātis, $f$. (xuII) . . (is quem līberāmus, lībertātem habet).

Licet, licēre, licuit (xvıI) . . . (rogā magistrum).

Lìmen, lìminis, $n$. (Iv) . . . (in Fōrmulā III).

Lingua, linguae, $f$. (xIII) . . . (rogā magistrum).

Littera, litterae, f. (Ix) . . . . (A, B, C, D, et c.: (plu.) id quod scrïbimus).

Locus, locī, m. (xviı) . . . . (ubi aliquid est).

Longus, longa, longum (viI) . . (rogā magistrum).

Loquāx, loquāx (xLıx). . . . (loquācēs sunt illī quī nimis loquuntur).

Loquor, loquī, locūtus sum

1 (xxxvıI) . . . . . . (aliquid dīcō).

Lūcidus, lūcida, lūcidum (xLviI) . (quod lūcem dat vel habet).

Lūdō, lūdere, lūsī, lūsum (Ix) . . (contrārium est Labōrō).

Lūdus, lūdī, m. (IX) . . . . . (ubi recitāmus et studēmus).

Lupus, lupī, m. (xI) . . . . (pict. XI).

Lũx, lūcis, $f$. (xxxvi) . . . . (contrārium est Tenebrae).

M

Macer, macra, macrum (xxxII) . (pict. XxxII).

Magis (xxıx). . . . . . (adverbium: cf. Maior).

Magister, magistrī, m. (xLviI) . (is quī in lūdō docet).

Magistrātus, magistrātūs, $m$.

(xxxII) . . . . . . (pict. XxxiI).

Magnitūdō, magnitūdinis, $f$.

(xi) . . . . . . (cf. Magnus).

Magnopere (xxix) . . . . (adverbium: cf. Magnus).

Magnus, magna, magnum (vıir) . . . . . . . (contrārium est Parvus).

Maior, maius (xxıı) . . . . (magnus, maior, maximus).

Malevolēns, malevolēns (xuIv) . (malevolentēs sunt illī quī malum volunt).

Mālō, mālle, māluī (xxxıI) . . (magis volō).

Mālum, mālī, n. (xuıv) . . . . (frūctus quī sēmen in sē ha. bet). 
Mālum Pūnicum, mālī Pūnicī, n. (xliv). . . . . . (pict. $\mathrm{xxxVI).}$

Malus, mala, malum (viII) . . (contrārium est Bonus).

Mālus, mālī, m. (xvıı) . . . . (pict. xvıi).

Māne (xxı) . . . . . . . (prīmā parte diēī).

Maneō, manēre, mānsī, mānsum (xxı̈) . . . . . . . . (contrārium est Eō).

Mānsuētus, mānsuēta, mānsuētum (xxvi) . . . . . (lupī sunt ferī : bonus canis est mānsuētus).

Manus, manūs, $f$. (III) . . . . . (in Fōrmulā II: nōnnūllī hominēs collectī).

Mappa, mappae, $f$. (III) . . . . (in Fōrmulā II).

Mare, maris, $n$. (XL) . . . . (pict. XvII).

Māter, mātris, $f .(\mathrm{XI})$. . . . (māter et pater sunt parentēs).

Mātrimōnium, mātrimōnī, $n$.

(xLIx). . . . . . (ubi vir uxōrem dūcit, mātrimōnium est).

Maximus, maxima, maximum (xviI) . . . . . . . (magnus, maior, maximus).

Medius, media, medium (xxI) . (rogā magistrum). Melior, melius (xxıx) . . . . (bonus, melior, optimus). Meminī, meminisse (xxı) . . (sciō et teneō id quod factum est).

Memorābilis, memorābile (L) . . (quod bonum est meminisse). Memoria, memoriae, $f$. (xxxvi) . (memoriā teneō: sciō quod iam actum est).

Mēns, mentis, $f$. (xxıI) . . . . (id quō cōgitāmus).

Mēnsa, mēnsae, f. (III) . . . (rogā magistrum).

Mënsis, mēnsis, $m$. (rx) . . . (xxx diēs).

Mentior, mentīī, mentītus sum (xxxvi) . . . . . . (falsum dīcō).

Mercātor, mercātōris, $m$. (xıII) . (is quī tabernam habet, et rēs vēndit).

Mereor, merērī, meritus sum (xlviII) . . . . . (mereor id quod mihi meritō venit). 
Merīdiēs, merīdiēī, m. (xxıII) . . (media pars diēī).

Meritō (xIII) . . . . . . (sî bonus puer bonam rem habet, meritō habet: sī malus puer bonam rem habet, nōn meritō habet).

Meus, mea, meum (viII) . . . (cf. Ego).

Mìles, mïlitis, m. (XXIv) . . . (is quĩ prō patriā pugnat).

Mìitāris, mīlitāre (xLvı). . . . (cf. Mīles).

Mille (plū. Mìlia) (xxxıI) . . . (numerus ... M.).

Minimus, minima, minimum (xxıv). . . . . . . . (parvus, minor, minimus).

Minor, minus (xxıII) . . . (parvus, minor, minimus).

Minor, minārī, minātus sum (xliI) . . . . . . . (dīcō "Malum tibi faciam").

Minūtus, minūta, minūtum $(\mathrm{xxx})$. . . . . . (minimus).

Mīrābilis, mīrābile (xııI) . . . . (quod vix erēdimus).

Mīror, mīrārī, mīrātus sum (xLIX). . . . . . (mīrābile vel optimum esse putō).

Misceō, miscēre, miscuī, mixtum (xxiv). . . . . . (rogā magistrum).

Miser, misera, miserum (xI) . . (quī dolet).

Misereō, miserēre, miseruī, miseritum (XIII). . . . . . (doleō, sī hominem dolēre

Misericordia, misericordiae, $f$. vidē̄).

(L) . . . . . . . (sī misereō, misericordiam adhibeō).

Mittō, mittere, mīsī, missum $(\mathrm{xxx})$. . . . . . . (dīcō alicui " $\overline{\mathrm{I}}$ ").

Mixtus, mixta, mixtum (xxx) . (quod miscēmus, mixtum est). Modestus, modesta, modestum (quĩ nōn dīcit dē virtūtibus (xxIv). . . . . . . suīs).

Modo - modo (xLII) . . . (prīmō - tum).

Modus, modī, m. (xxvi) . . . (cf. Quō modō). 
Mōmentum, mōmentī, $n$.

(xxxir) . . . . . . (id quod aliquid movet: paulum).

Moncō, monēre, monuī, moni-

tum $\left(\mathrm{xL}^{2}\right.$. . . . . . (malum videō, et alicui dīēo "Fuge": cōnsilium dō).

Mōns, montis, $m$. (xxI) . . . (pict. Xxr).

Mora, morae, $f$. (xxiv) . . . (sī quid nōn statim facimus, mora est).

Mordāx, mordāx (xııI) . . . (dīcō mordācem esse linguar: quae mordeat).

Mordē̄, mordēre, momordī, morsum (xIrI) . . . . . (rogā magistrum).

Morior, morī, mortuus sum (xxıv). . . . . . . (vitam āmittō).

Mors, mortis, $f$. (xI) . . . (pict. $\mathrm{xI})$.

Mortālis, mortāle (xxxıx) . . . (quī morī potest).

Mortifer, mortifera, mortiferum (xxr) . . . . . (quod mortem fert).

Mōs, mōris, m. (xlvi) . . . . . (cōnsuētūdō).

Moveō, movēre, mōvī, mōtum (xx) . . . . . . (cf. Commoveō). Mox (xxvi) . . . . . . (nōn multō post). Mūcrō, mūcrōnis, m. (L) . . . . (ācer fīnis cultrī).

Mūgiō, mūgīre, mūgīvī, mūgìtum (xxIr). . . . . . (ubi bōs aliquid dīcit, mūgit). Mulier, mulieris, $f$. (xxıv) . . (māter est mulier, sed nōn

Multitūdō, multitūdinis, $f$. puella, nōn pater). (XLII) . . . . . . . . (magnus numerus).

Multus, multa, multum (Ix) . (ccclxxvii sunt multa: iii sunt pauca).

Mundus, munda, mundum (viri) . (rogā magistrum). Mundus, mundī, $m$. (xliv) . . (omnēs terrae et maria quae sub sōle sunt).

Mūniō, mūnīre, mūnīvī, mūnītum (xLvi). . . . . . (mūnītiōnem faciō). 
Mūnitiō, mūnītiōnis, $f$. (xLIII) . (mūrus quī ab hostibus dēfendit).

Mürus, mūrī, m. (xLII) . . . (pict. Xxxvi).

Mūs, mūris, $m$. vel $f$. (xxxiı) . . (pict. XxxıI).

Mūtō, mūtāre, mūtāvī, mūtā-

tum (xLIV). . . . . . (genus reī aliud faciō, et nōn iam eadem est).

Mūtus, mūta, mūtum (xLIx) . . (quī loquĩ nōn potest).

\section{N}

Nam (xxiv) . . . . . . (enim).

Nārrō, nārrāre, nārrāivī, nārrā-

tum (xi) . . . . . . (fābulam dīcō).

Nāscor, nāscī, nātus sum

(xxıv). . . . . . . (prīmum nāscimur, deinde vītam agimus, tertium mors venit).

Nātiō, nātiōnis, $f$. (xLvi) . . . . (gēns).

Nātūra, nātūrae, $f$. (xuıv) . . . (Nātūra in sē continet omnia quae nāta sunt).

Nauta, nautae, $m$. (xviI) . . (pict. xviI).

Nāvālis, nāvāle (xviı) . . . . . (cf. Nāvis).

Nāvis, nāvis, $f$. (xviI) . . . . . (pict. xviI).

Necessārius, necessāria, neces-

sārium (xLVIII) . . . . . (necesse: eiusdem generis: amīcus).

Necesse (xvir) . . . . . (rogā magistrum).

Necō, necāre, necāvī, necātum

(L) ........... (interficiō).

Negō, negāre, negāvī, negātum (xxxiI) . . . . . . . (dīcō "Nōn").

Negōtium, negōtī, $n$. (xLviıI) . . (id quod cōnsuētūdine, vel nōn facile, faciō).

Nēmō, nēminī (dat.), $m$. vel $f$. (xLII) . . . . . . (nūllus homō).

Neptis, neptis, $f .(\mathrm{xI}) \ldots .$. (puella quae aviam habet). 
Neque vel Nec (xv). . . . (et nōn).

$\mathrm{N} \overline{\mathrm{e}}$ - quidem (xxi) . . . . ( $\operatorname{rogā}$ magistrum).

Nescius, nescia, nescium ( $x x x)$. (quī nōn scit).

Neuter, neutra, neutrum

(xxvi) . . . . . . (neque hoc neque illud).

Niger, nigra, nigrum (xxxıx) . (color: rogā magistrum).

Nihil (xv) . . . . . . (nūlla rēs: nōn).

Nimis (xxxir) . . . . . (magis quam bene est).

Nōbilis, nōbile (xLIII) . . . . (illūstris: nōn ignōtus).

Noceō, nocēre, nocuī, nocitum

(xvi) . . . . . . . (alicui malum faciō).

Nōlī hoc facere (xviI) . . . . (contrārium est "Hoc fac").

Nōlō, nōlle, nōluī (xxxviıI) . . (nōn volō).

Nōmen, nōminis, $n$. (xI) . . . (rogā magistrum).

Nōndum (xv) . . . . . . (contrārium est Iam).

Nōnus, nōna, nōnum (xx) . . . (cf. Novem: cf. quoque Prīmus, et c.).

Nōscō, nōscere, nōvī, nōtum $(\mathrm{xxx})$. . . . . . . (scīre incipiō).

Noster, nostra, nostrum (viII) . (cf. Nōs).

Notō, notāre, notāvī, notātum

(xxxıv) . . . . . . (indicō: videō).

Novem (IX) . . . . . . . (numerus ... Ix).

Novus, nova, novum (vili) . . . (contrārium est Vetus).

Nox, noctis, $f$. (xxı) . . . . (ubi sōlem nōn vidēmus: ubi dormīmus).

Nūbēs, nūbis, $f$. (xxI) . . . . . (pict. XxI).

Nūbō, nūbere, nūpsī, nūptum

(xxıv) . . . . . . (ubi vir uxōrem dūcit, illa virō nūbit).

Nudiūs (xxxııı) . . . . . . (nunc diēs est).

Nūdō, nūdāre, nūdāvī, nūdātum (xLVI). . . . . . (āmoveō id quod super aliquid est, vel aliquid dēfendit).

Nūllus, nūlla, nūllum (xviI) . . (nōn ūnus, nōn paucī, nōn multī).

Numerus, numerī, m. (xxxiI) . (ūnus, duo, trēs, et c.). 
Nummus, nummī, m. (xiri) . . (rogā magistrum).

Numquam (xıII) . . . . . (contrārium est Semper).

Nunc (xvil) . . . . . . (hōc tempore).

Nüntiō, nūntiāre, nūntiāvì,

nūntiātum (xLIII) . . . . . (nūntium ferō: rem novam dīcō).

Nūntius, nūntĩ, $m$. (xxxiI) . . . (is quĩ litterās portat: litterae quās nūntius portat).

\section{0}

Obiciō, obicere, obiēcī, obiectum (xLII) . . . . . . . (alicui in viam iaciō).

Oblīvisscor, oblīìiscī, oblītus sum (xxxvi) . . . . . (ex memoriā āmittō).

Obsecrō, obsecrāre, obsecrāvì, obsecrātum (xxıv) . . . . (rogōō).

Obses, obsidis, $m$. vel $f$. (xLviII) . . . . . . (homō quem hostēs capiunt, ut prō aliquō posteā reddant).

Obtineō, obtinēre, obtinuī, obtentum (xLviII). . . . . (teneō: mihi capiō).

Occīdō, occīdere, occìdī, occīsum (xxxII) . . . . . . (mortuum faciō).

Occupō, occupāre, occupāvī, occupātum (xLvi) . . . . (capiō).

Occurrō, occurrere, occurrī, occursum (xvi) . . . . . (ad aliquem currō).

Octāvus, octāva, octāvum (xxviI) ....... (cf. Octō: cf. quoque Prīmus, et c.).

Octō (Ix) ........ (numerus . . V viII). Oculus, oculī, $m .(\mathrm{x}) \ldots$. . (oculīs videō).

$\bar{O}$ dī, ōdisse (xxxıx) . . . . (contrārium est Amō).

Officium, officī, $n$. (xuIx) . . . (id quod facere debēmus).

Oleum, oleĩ, $n$. (L) . . . . . (aliquid pingue quod ex olīvīs capimus). 
Ōlim (xxı) . . . . . . . . (longē antehāc, vel longē posthāc).

Olīva, olīvae, $f$. (L) . . . . (pict. Xxxvi).

Omnīnō (xıII) . . . . . . (sī tōtum frūctum edō, frūctum omnīnō edō).

Omnis, omne (xxıII) . . . . (tōtus: contrārium est Pars).

Opiniō, opīniōnis, $f$. (xLviII) . . (id quod opīnor: id quod alius dē mē opinātur).

Opīnor, opīnārī, opīnātus sum $(\mathrm{xxx}) \ldots \ldots$ (putō). . . .

Oportet, oportēre, oportuit (xurv) . . . . . . (bene est: necesse est).

Oppidum, oppidī, $n$. (xxvi) . . (urbs parva). .

Opprimō, opprimere, oppressī, oppressum (xvi) . . . . (aliquem sub mē tenēo, et male faciō).

Optimus, optima, optimum (xxiv). . . . . . . (bonus, melior, optimus).

Opus, operis, $n$. (xLvi) . . . (labor: id quod ex labōre fit). Ōrātiō, ōrātiōnis, $f$. (xLvin) . (modus dīcendī: sī ante multōs dīcō, ōrātiōnem habēō).

Orbis, orbis, m. (L) . . . . . (rogā magistrum).

Ōrdō, ördinis, $m$. (xlvi) . . . . (modus in quō rēs pōnuntur). Orior, orīīi, ortus sum (xxxix) . (surgō).

Ōrnō, ōrnāre, ōrnāvī, ōrnātum (xuIv). . . . . . (aliquid pulchrum faciō).

Os, ossis, $n$. (xxIx) . . . . (pict. xxIII).

Ostendō, ostendere, ostendī, ostentum (xvi) . . . (fortasse digitum in aliquid intendō).

\section{$\mathbf{P}$}

Paene (xvir) . . . . . (nōn omnīnō, sed nōn multō minus).

Pāgina, pāginae, $f .(x) . .$. . (in Fōrmulā Iv).

Palma, palmae, $f .(\mathrm{xxx}) \ldots \ldots$ (pēs plantam habet: manus palmam habet). 
Pānis, pānis, $m .(\mathrm{xxx}) \ldots$. . . (pict. xxıII).

Papȳrus, papȳrī, $m .(\mathrm{x})$. . . . (in papȳrō scrībimus stilō vel calamō).

Pār, pār (xL) . . . . . . . . (parēs sunt aéquī, similēs).

Parcō, parcere, pepercī, parsum (xviı) ....... (sī quem meritō feriam, nōn feriō).

Parēns, parentis, $m$. vel $f$. (xxxiI) . . . . . . (pater vel māter).

Pāreō, pārēre, pāruĩ, pāritum (xvi) . . . . . . (faciō id quod imperās).

Pariēs, parietis, $m$. (III) . . . . (rogā magistrum).

Parō, parāre, parāvī, parātum

(xviI). . . . . . (alicuid faciō, capiō, dō).

Pars, partis, $f .(\mathrm{x})$. . . . (dīmidium est pars: pāgina est pars librī).

Parvus, parva, parvum (viII) . . (rogā magistrum).

Passus, passūs, $m$. (Ix) . . . . (duo gradūs).

Pater, patris, $m$. (xI) . . . . . (is cuius nōmen habeō).

Patior, patī, passus sum

(xxxıx) . . . . . (doleō: ferō: permittō).

Patria, patriae, $f$. (xiı) . . . (Rōma est patria Rōmānōrum: America est patria Americānōrum).

Paucus, pauca, paucum (xiII) . (contrārium est Multus).

Paulisper (xlvi) . . . . (contrārium est Diū).

Paulum (xxix) . . . . (adverbium: cf. Parvus).

Pauper, pauper $(\mathrm{xI}) \ldots .$. (pauperēs nōn multum possident).

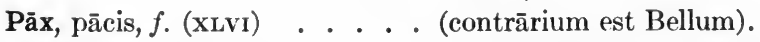

Pecūnia, pecūniae, $f$. (xıII) . . . (id quod capiō sĩ quid vēndō).

Pedes, peditis, $m$. (xlviI) . . (mîles quī in pedibus pugnat).

Peior, peius (xxıx) . . . (malus, peior, pessimus).

Pellō, pellere, pepulī, pulsum

(xLvi) . . . . . . . . (ā mē agō vel iaciōo cf. Expellō).

Per (cum acc.) (Iv) . . . . . (in Fōrmulā III). 
Pereō, perīre, perī̄, peritum (xxxiI) . . . . . . (morior).

Perficiō, perficere, perfēcī, perfectum (xlix) . . . . . (omnīnō faciō).

Perīculōsus, perīculōsa, perīculōsum (L) . . . . . . (quod perīculum in sē habet).

Periculum, perīeulī, $n$. (xLviı) . (malum quod mihi minātur: sī experior, perīculum faciō).

Perlegō, perlegere, perlēgī, perlēctum (xv) . . . . . (tōtum legō).

Permagnus, permagna, permagnum (xxI) . . . . . (maximus).

Permittō, permittere, permīsī, permissum (xvir) . . . . (contrārium est Vetō).

Permultus, permulta, permultum (xxxiı) . . . . . . . (plūrimus).

Pernōtus, pernōta, pernōtum (xxxvi) . . . . . . . (quod bene scīmus).

Perpetuus, perpetua, perpetuum (xxiv) . . . . . (quod semper erit).

Persequor, persequĩ, persecūtus sum (xlvi) . . . . . . (diū sequor).

Perspiciō, perspicere, perspexī, perspectum (xuiv) . . . . (bene videō).

Persuādeō, persuādēre, persuāsī, persuāsum (xVI) . . . . (dīcō, et crēdis vel facis id quod dēsīderō).

Perterreō, perterrēre, perterruī, perterritum (xxxıx) . . . (multum terreō).

Pertineō, pertinēre, pertinuī (xLVIII) . . . . . (mihi pertinent omnia quae mea sunt vel quae mēcum coniūncta sunt).

Perveniō, pervenīre, pervēnī, perventum (xIII) . . . . (ad rem veniō). Pēs, pedis, m. (Ix) . . . . (in Fōrmulā IV: xii ūnciae). 
Pessimus, pessima, pessimum (xIII) . . . . . . (malus, peior, pessimus).

Petō, petere, petīìi, petītum (xxix). . . . . . (ad rem eō: dēsīderō).

Pictūra, pictūrae, $f .(\mathbf{x})$. . . . (in Fōrmulā IV).

Pietās, pietātis, $f$. (xvir) . . . . (amor patris vel patriae).

Piger, pigra, pigrum (xviiI) . . (quī labōrāre nōn volt).

Pinguis, pingue (xxxII) . . . (contrārium est Macer).

Pīrāta, pīrātae, m. (L) . . . . . (is quī nāve suā aliōrum navēs capit et pecūniam rapit).

Pius, pia, pium (xviI) . . . . (quī patrem et patriam amat).

Placenta, placentae, $f .(\mathrm{xxIx})$. (pict. $\mathrm{xI})$.

Placeō, placēre, placuī, placitum $(\mathrm{L}) \ldots \ldots$ (gaudium dō: bonus esse videor).

Plāga, plāgae, $f .(\mathrm{xvI})$. . . . . (in Fōrmulā rv).

Planta, plantae, $f$. (xII) . . . . (in Fōrmulā IV).

Plaudō, plaudere, plausī, plausum (xxi) . . . . . (rogā magistrum).

Plēnus, plēna, plēnum $(\mathbf{x})$. . . (rogā magistrum).

Plērīque, plēraeque, plēraque

(xuIV). . . . . . . . (ferē omnēs).

Plērumque (xusv). . . . . . (ferē omnīnō).

Plūrimus, plūrima, plūrimum

(xxxıI) . . . . . . . (multus, plūs, plūrimus).

Plūs, plūris (gen.) (xxx) . . . (multus, plūs, plūrimus).

Poena, poenae, $f$. (xuIv) . . . . (ubi aliquis mē pūnit, ego poenam dō).

Polliceor, pollicērī, pollicitus sum (xuI1)...... (aliquid vīs: dīcō "Hoc faciam").

Pompa, pompae, f. (xxiv) . . . (pict. xxIv).

Pōnō, pōnere, posuī, positum

(II) . . . . . . . (rogā magistrum).

Pōns, pontis, $m$. (xxIII) . . . . (pict. XxiII).

Populus, populī, $m$. (xuıv) . . . (hominēs: gēns). 
Porrigō, porrigere, porrēxī, porrēctum (x)..... . . (in Fōrmulā IV).

Porta, portae, $f$. (xlIII) . . . . (iānua).

Portentum, portentī, n. (L) . . . (id quod indicat aliquid mīrābile futūrum esse).

Portō, portāre, portāvī, portātum (IX) . . . . . . . . (rogā magistrum).

Possessor, possessōris, $m$. (x) . (is quī possidet).

Possideō, possidēre, possēdī, possessum (x) . . . . . . (habeō: tencō: meum est).

Possum, posse, potuī (xxıII) . . (rogā magistrum).

Post (cum acc.) (IV). . . . . . (in Fōrmulā III).

Posteã (xxı) . . . . . . . . (post eās rēs).

Posterus, postera, posterum (xlviil) . . . . . . (quī post aliōs est).

Posthāc (xxı) . . . . . (post hoc tempus).

Postrēmus, postrēma, postrēmum (xxxix) . . . . (posterus (post), posterior, postrēmus).

Postrīdiē (xlvini) . . . . . (posterō diē).

Postulō, postulāre, postulāvī, postulātum (xviıI) . . . . (dīcō "Dā mihi").

Potestās, potestātis, $f$. (xLviıI) . (vīrēs, imperium, auctōritās). Potior, potīī, potītus sum (xxxil) . . . . . . (meum faciō).

Potius (xlIV). . . . . . . (magis).

Praecēdō, praecēdere, praecessī, praecessum (xxvi) . . . . (ante e⿳亠丷).

Praeficiō, praeficere, praefēcī, praefectum (XVI) . . . . (magistrum vel dominum faciō).

Praemittō, praemittere, praemīsī, praemissum (xLVI) . . . (ante mē mittō).

Praemium, praemī, $n$. (xxxıI) . (id quod mihi datur, sĩ cui bonum faciō).

Praepōnō, praepōnere, praeposuī, praepositum (xvIII) . . (praeficiō). 
Praesēns, praesēns, (gen. praesentis) (viII) . . . . . (contrārium est Absēns).

Praesertim (xLVIII) . . . . (magis quam alia).

Praesidium, praesidī, $n$. (xxxıv) . (id quod dēfendit).

Praestō, praestāre, praestitī, praestātum (xvi) . . . . (sī mē praeficis, ego praestōo).

Praesum, praeesse, praefuī (xvi) . . . . . (superior sum).

Praetereā (xLvi) ...... (quoque).

Praetereō, praeterïre, praeteriī, praeteritum (xLII) . . (prope aliquem e⿳亠丷, deinde ab illō prōcēdō).

Praetermittō, praetermittere, praetermisīi, praetermissum (xuIx) . . . . . . (permittō ut praetereat).

Prandium, prandī, $n$. (xL) . . . (id quod merīdiē edimus).

Precēs, precum, $f$. (xuIv) . . . (id quod dícimus ubi deum aliquid rogāmus).

Prehendō, prehendere, prehendī, prehēnsum (xLIX). . . . . . (capiō: rapiō).

Premō, premere, pressī, pres$\operatorname{sum}(\mathbf{x x x}) \ldots . . . \quad(\operatorname{rog} \bar{a}$ magistrum).

Pretium, pretī, $n$. (L) . . . . (id quō aliquid emimus).

Prìdiē (xxxıII) . . . . . (priōre diē).

Prìmus, prīma, prīmum (xIII) . (cf. "Fōrmula Prīma").

Prīnceps, prīncipis, $m$. (xLVIII) . (dux: imperātor).

Prior, prius (xxvi) . . . (- prō -, prior, prīmus).

Prīvātus, prīvāta, prīvātum (xlviII) . . . . . . (contrārium est Pūblicus).

Prō (cum abl.) (xix) . . . . . (in Fōrmulā Iv).

Probō, probāre, probāvi, probātum (xLviI) . . . . . (aliquid bonum esse dīcō vel

Prōcēdō, prōcēdere, prōcessī, putō).

prōcessum (xxıv) . . . . . (ad illa quae ante sunt ē̄).

Procērus, procēra, procērum

(xxxir) ......... (altus). 
Proelium, proelī, n. (xxvi) . . . (pugna).

Prōferō, prōferre, prōtulī, prōlātum (L) . . . . . . . (prō + ferō: in tempus futūrum ferō).

Proficiscor, proficīscī, profectus sum (xLIv). . . . . (prōgredior).

Prōgredior, prōgredī, prōgressus sum (XLII)

(prōcēdō).

Prohibeō, prohibēre, prohibuī, prohibitum (xLIV). . . . (aliquem ab aliquō habeō vel teneō).

Prōnōmen, prōnōminis, $n$. (xxvi). . . . . . (e.g. Ego, Ille, Vōs).

Prope (xxıv) . . . . . . (contrārium est "Longē ab"). Properō, properāre, properāvī, properātum (xxI) . . . . (celeriter eō).

Propinquus, propinqua, propinquum (xL) . . . . . (prope).

Prōpōnō, prōpōnere, prōposuī, prōpositum (xvi) . . . . (ante aliquem pōnō).

Propter (cum acc.) (xx) . . . . (respondet quaestiōnī "Cūr?", xx).

Proptereā quod (xxviI) . . . . (cf. Propter).

Prōspiciō, prōspicere, prōspexī, prōspectum (xxI) . . . . . (cōnspiciō).

Prōvideō, prōvidēre, prōvīdī, prōvīsum (xLIV) . . . . . (parō: id quod erit videō).

Prōvincia, prōvinciae, $f$. (xuIx) . (terra nōn in İtaliā quam Rōmānī regēbant).

Proximus, proxima, proximum (xlVI). . . . . . . (prope, propior, proximus).

Püblicus, pūblica, pūblicum

(xLVIII) . . . . . . (quod populō pertinet).

Puella, puellae, $f$. (III) . . . . (rogā magistrum).

Puer, puerī, m. (III) . . . . . (rogā magistrum).

Pugna, pugnae, $f$. (xvII) . . . . (pict. xvir: vel rogā magistrum). 
Pugnō, pugnāre, pugnāvī, pugnātum (xxıv) . . . . . (pugnam faciō).

Pulcher, pulchra, pulchrum (xi) . (quod bonum est vidēre). Pulchritūdō, pulchritüdinis, $f$. (xIII) . . . . . . . . (cf. Pulcher).

Pūniō, pūnīre, pūnīvī, pūnītum (xxxvi) . . . . . . (sī puer malus est, e.g., eum feriō, vel lūdere nōn permittō).

Putō, putāre, putāīi, putātum

(vi) . . . . . . . (cf. Dīcō in Pēnsō vi).

\section{Q}

Quaerō, quaerere, quaesīvī, quaesītum (xxxıv) . . . . . (rogō id quod nōn sciō).

Quaestor, quaestōris, m. (xLIX) . (is quī pecūniam Rōmānōrum cūrābat).

Quaestus, quaestūs, m. (xviII) . (v nummīs rem capiō:

viII nummīs vēndō:

III nummī sunt quaestus).

Quālis, quāle (vıI) . . . . (quaestiō in Pēnsō viı).

Quam (IX) . . . . . . (quaestiō in Pēnsō Ix).

Quam (xxxı) . . . . . (post comparātīvum).

Quam diū (IX) . . . . . (quaestiō in Pēnsō IX).

Quamobrem (xxviı) . . . (cūr).

Quamquam (L) . . . . . (ultimum "cum" in Pēnsō XLV).

Quandō (xx) . . . . . (quaestiō in Pēnsō xx).

Quantum, quantī, n. (x) . . . (quaestiō in Pēnsō x).

Quantum spatī (IX) . . . . . (quaestiō in Pēnsō IX).

Quantus, quanta, quantum

(xlII) . . . . . . . (quaestiō: cf. Tantus̀).

Quārē (xlvi). . . . . . (quā dē causā).

Quārtus, quārta, quārtum

(xlviII)....... (ef. Quattuor: cf. quoque Prīmus, et c.).

Quasi (xLVIII) . . . . (eōdem modō ac). 
Quattuor (Ix) . . . . . (numerus ... IV).

Queror, querī, questus sum

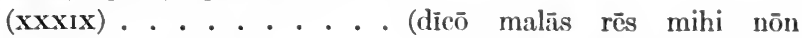
meritō vēnisse).

Quī, quae, quod (xxxıv) . . (in Pēnsō xxxıv, infrā).

Quicumque, quaecumque,

quodcumque $(\mathrm{xxxIx})$. . . (omnis).

Quidam, quaedam, quiddam

(xxıv). . . . . . . (ūnus dē quō maximē putō vel dīcō).

Quidem (xliv) . . . . . (vērō).

Quinque (Ix) . . . . . (numerus ... v).

Quis, quid (v) . . . . . (quaestiō in Pēnsō v).

Quisque, quaeque, quidque

(xxxvi) . . . . . . (omnēs singulī - singulārēs).

Quō (xI). . . . . . . (quam in partem).

Quōmodo (xx) . . . . . (quaestiō in Pēnsō xx).

Quondam (xviıI) . . . . (longē antehāc).

Quoniam (xxxvi). . . . . (cum iam: proptereā quod).

Quoque (xI) . . . . . . ("hoc quoque" est "et hoc").

Quot (Ix) ....... (quaestiō in Pēnsō IX).

\section{R}

Racēmus, racēmī, $m$. (xv) . . (pict. Xv).

Rāmus, rāmī, m. (xv) . . . . (pict. xv).

Rapiō, rapere, rapuī, raptum (I) . (in Fōrmulā I).

Ratiō, ratiōnis, $f$. (XlvıI) . . . . (modus: cōnsilium: sī ēnumerō, ratiōnem dūeō).

Recipiō, recipere, recēpī, receptum (xxxıI) . . . . . (iterum capiō).

Recitō, recitāre, recitāvī, recitātum (IX) . . . . . . . (rogā magistrum).

Rēctus, rēcta, rēctum (xxıv) . . (rogā magistrum).

Recūsō, recūsāre, recūsāvī, recūsātum (xxxvııI) . . . . (mē aliquid rogās: dīcō tibi, "Nōn faciam. Nōlō"). 
Reddō, reddere, reddidī, redditum (xxxı́) . . . . . . (dō illī ā quō aliquid accēpī).

Redeō, redīre, redī̄, reditum (XVIII). (abiī: sī nunc adveniō, redeō).

Referō, referre, rettulī, relātum

(xL). . . . . . . . . (ad locum ferō ubī antea erat).

Regiō, regiōnis, $f$. (xxxix) . . . (pars terrae vel caelī).

Rēgnum, rēgnī, $n$. (xL) . . . (terra quam aliquis regit).

Regō, regere, rēxī, rēctum

$$
\text { (xviII). . . . . . . (imperō). }
$$

Rēgula, rēgulae, $f$. (IX) . . . . (rogā magistrum).

Rēiciō, rēicere, rēiēcī, rēiectum (xlvi) . . . . . . . . . (ab aliquō locō iaciō).

Relinquō, relinquere, relīquī, relictum (xvII) . . . . . . (ab aliquō discēdō).

Reliquus, reliqua, reliquum (xxıII). . . . . . . (quod relinquimus).

Remittō, remittere, remīsī, remissum (xxx) . . . . . (ā mē ad alium locum mittō).

Renūntiō, renūntiāre, renūntiāvī, renūntiātum (xLViII) . (nūntiōo).

Reperiō, reperīre, repperī, repertum (XI) . . . . . . (rogā magistrum).

Rès, reī, f. (IX) . . . . . . . . (rogā magistrum).

Resistō, resistere, restitī (xxIv) . (sī quis mē agere volt, contrā illum stō).

Resolvō, resolvere, resolvī, resolūtum (xxi) . . . . . . (contrārium est Revinciō).

Respondeō, respondēre, respondī, respōnsum (XI) . . . (mihi dīcis: sī posteā tibi dīcō, tibi respondē̄).

Restō, restāre, restitī (xxı). . . (nōndum abiī: id quod relinquimus restat).

Retineō, retinēre, retinūi, retentum (xxıv) . . . . . (ab aliquō teneō).

Revertor, revertere, revertī, reversum (xxxiI)...... (redeō). 
Revinciō, revincīre, revīnxī, revinctum (xxI) . . . . . (pict. XXI).

Revocō, revocāre, revocāvī, revocātum (xLVI) . . . . (ab aliquō locō vocō).

Rēx, rēgis, $m$. (L) . . . . . (is quī terram regit).

Ripa, rīpae, $f$. (xlvi) . . . . (terra proxima ad flūmen).

Rivus, rīvī, $m$. (xxxıx) . . . (parvum flūmen).

Rogō, rogāre, rogāvì, rogātum

(xxxıI) . . . . . . (dīcō "Dā vel dīc mihi aliquid").

Ruber, rubra, rubrum (XI) . . (color: rogā magistrum).

Rudis, rude (xxıv) . . . . (agricola in fundō est rudis: cīvis in urbe fortasse nōn).

Rūmor, rūmōris, $m$. (xxIv). . . (id quod omnēs dīcunt, sed nōn vērō sciunt).

Ruō, ruere, rūi, rutum (xxIv) . . (celeriter eō: cadō).

$\mathbf{S}$

Saccus, saccī, m. (x) . . . (rogā magistrum).

Saepe (XII). . . . . . . (rogā magistrum).

Saevus, saeva, saevum (xxx) . . (ferus: crūdēlis).

Salūs, salūtis, $f$. (xlviı) . . . . ("Salūtem ferō," id est, Servō). Salvē (xı) . . . . . (aliquem vidēmus, gaudēmus, "Salvē" dícimus).

Sanguis, sanguinis, m. (xxv) . . (ruber est: vidēmus sī digitum caedimus).

Sapiēns, sapiēns (xvıII) . . (sapientēs sunt illī quī multa sciunt).

Satis (xv) . . . . . . . . (quantum dēsīderāmus).

Sāturnus, Sāturnī, $m$. (xxxvi) . (deus quīdam Rōmānōrum: eius diē fēriās habēmus).

Scelerātus, scelerāta, scelerātum (XVIII) . . . . . . (pessimus).

Sciō, scīre, scīvī, scītum (vi) . . (cf. Dīcō in Pēnsó vi).

Scrībō, scrībere, scrīpsī, scrīptum (II) . . . . . . (rogā magistrum). 
Scrīptor, scrīptōis, m. (x) . . . (is quī scrībit).

Scrīptūra, scrīptūrae, $f$. (xLvII) . (id quod scrïbitur: modus scrībendī).

Scūtum, scūtī, n. (xlviıI) . . . (pict. XLVI).

Secundum (cum acc.) (XLVI) . . (eōdem modō ac).

Secundus, secunda, secundum

(xviII). . . . . . . (quod post prīmum est).

Secūris, secūris, $f$. (xxi) . . . . (pict. xxxvi).

Sedeō, sedēre, sēdī, sessum (xL) . (cōnsēdī).

Sella, sellae, $f$. (III) . . . . . (rogā magistrum).

Sēmen, sēminis, $n$. (xuıv) . . . (id quod in terrā serimus, ut aliquid ex eō crēscat, e.g., faba).

Semper (xIII). . . . . . (per tōtam hōram: per tōtum annum).

Senātus, senātūs, $m$. (xLviır) . . (senēs, quī in cīvitāte imperant).

Senex, senis, $m$. (xxI) . . . . (vir vetus: cf. Anus).

Sententia, sententiae, $f$. (xxvi) . ("pēnsum" nōn est sententia: sed "pēnsum est longum" est sententia).

Sentiō, sentīre, sēnsī, sēnsum (x) . (per aurēs, per oculōs, etc., intellegō).

Sepeliō, sepelīre, sepelīvĩ, sepultum $(\mathrm{xxIx})$. . . . (illum quĩ mortuus est in terrā pōnō).

Septem (Ix) . . . . . . (numerus ... VII).

Septimus, septima, septimum

(xlviı) . . . . . . (cf. Septem: cf. quoque Prīmus, et c.).

Sequor, sequī, secūtus sum

$(\mathrm{xxx})$. . . . . . . (post aliquem eō).

Sermō, sermōnis, m. (xxırv). . . (id quod dīcimus).

Serō, serere, sēvī, satum (xxi) . (pict. xxi).

Servātor, servātōris, $m$. (xI) . (is quī ā malō, $\bar{a}$ morte, rapit).

Servō, servāre, servāvī, servā-

tum (xLIv). . . . . ( $(\bar{a}$ malō, ā morte, rapiō). 
Servus, servī, m. (xviri) . . . (homō quem homō possidet).

Sevēritās, sevēritātis, $f$. (xxxvi) . (cf. Sevērus).

Sevērus, sevēra, sevērum

(xxxvI) . . . . . (sevērus pater gravis est in malōs līberōs).

$\operatorname{Sex}(\mathbf{I x}) . . . . . . .($. . (numerus ... VI).

Sìc (xxxıı). . . . . . . (

Sìcut (xlviıi). . . . . . . . (eōdem modō ac).

Significātiō, significātiōnis, $f$.

(xLVII) . . . . . . (signum: id quod aliquid significat).

Significō, significāre, signifi-

cāvì, significātum (xxv) . . . (rogā magistrum).

Signum, signī, $n$. (xlvi) . . . (effigiēs: rēs quā aliquid indicāmus).

Silentium, silentĩ, $n .(\mathrm{xxx})$. . . (sī nūllus sonitus est; silentium est).

Silva, silvae, $f .(\mathrm{XI})$. . . . (pict. $\mathrm{xI}$ ).

Similis, simile (xxvi) . . . (ferē ìdem).

Sine (cum abl.) (xıx) . . . . (in Fōrmulā Iv).

Singulāris, singulāre (xxr) . . . (nōn similis alī̄s).

Sinister, sinistra, sinistrum (Xxi) . . . . . . . (contrārium est Dexter).

Sinus, sinūs, $m .(\mathrm{xL})$. . . (rogā magistrum).

Socius, socī, m. (xLvi) . . . . (is quī aliquid cum aliō facit).

Sōl, sōlis, m. (XXI) . . . . . . (pict. XV).

Solea, soleae, $f .(\mathrm{xxx})$. . . . (calceus: inferior pars calceī).

Sōlus, sōla, sōlum (xvII) . . . . (ūnus: sine aliō).

Somniō, somniāre, somniāvī,

somniātum (xıII) . . . . (dormiō, et putō mē aliquil facere).

Somnus, somnī, $m$. (xxxıx) . . (sī dormīmus, somnum capimus).

Sonitus, sonitūs, m. (xxI) . . . (id quod audīmus, neque tantummodo vōcēs).

Sonō, sonāre, sonūi, sonitum (xxII) . . . . . . (sonitum faciō). 
Sordidus, sordida, sordidum (viri) . . . . . . . (contrārium est Mundus). Soror, sorōris, $f$. (xxxıv) . . . . (fīlia meī patris est mea soror). Spatium, spatī, $n$. (xxvi) . . (quantum ūna rēs ab alterā rē abest).

Spectō, spectāre, spectāvī, spectātum (I) . . . . . . (in Fōrmulā I).

Spès, speī, $f$. (xxıv) . . . . . . (sĩ bonum exspectō, spem

Spīrō, spīrāre, spīrāvī; spīrāhabeō). tum (xxII) . . . . . . . (rogā magistrum).

Splendeō, splendēre (xxxıx) . . (lūcem ex mē dō).

Statim (xxI) . . . . . (nunc: eōdem tempore).

Statuō, statuere, statuī, statūtum (xuIv). . . . . (cōnstituō).

Sterilis, sterile (xıII) . . . . (quod frūctum nōn dat).

Sterilitās, sterilitātis, $f$. (xıII) . . (cf. Sterilis).

Stilus, stilī, m. (Ix) . . . . . (rogā magistrum).

Stipula, stipulae, $f$. (xxI) . . . (pict. $\mathrm{xxI})$.

Stō, stāre, stetī, stātum (IV) . . (in Fōrmulā III).

Strepitus, strepitūs, $m .(\mathrm{xxx})$. . (sonitus mixtus).

Studeō, studēre, studuī (xvi) . . (alicui bonās rēs dēsīderō).

Stultus, stulta, stultum (xxIv) . (stupidus).

Stupiditās, stupiditātis, $f .(\mathrm{x})$. . (cf. Stupidus).

Stupidus, stupida, stupidum (x) . (quĩ nōn multa scit, nōn ēdiscit).

Sub (cum abl.) (xıx) . . . . . (in Fōrmulā Iv).

Subigō, subigere, subēgī, sub$\operatorname{actum}(\mathrm{L}) \ldots \ldots$ (superō).

Subitō $(\mathrm{xI}) \ldots \ldots$. (subitō venit id quod nōn exspectāmus).

Subitus, subita, subitum (xvir) . (cf. Subitō).

Subsidium, subsidī, $n$. (xLviII) . (auxilium).

Subter (cum acc.) (IV) . . . . . (in Fōrmulā III).

Suī, sibi, sē, sē (v) . . . . . . (rogā magistrum: cf. Pēnsum vi).

Sum, esse, fuĩ, futūrum (xxxi) . (cf. Pēnsum xxiII, innfrā). 
Summus, summa, summum (xxI) . . . . . . . (superus, superior, suprēmus vel summus).

Sūmō, sūmere, sūmpsī, sūmptum (xurv). . . . . . . (capiō).

Super (cum acc.) (IV) . . . . (in Fōrmulā III).

Superior, superius (Ix). . . . . (superus, superior, suprēmus).

Superō, superāre, superāvī,

superātum (xuIv) . . . . . (victōriam ferō).

Supersum, superesse, superfuī (xLVI). . . . . . . (reliquus sum).

Superus, supera, superum (xliv) . (cf. Super).

Supplex, supplex, (acc. supplicem) (xxv) . . . . . (in Fōrmulīs Neutrī Generis). Suppōnō, suppōnere, supposuī, suppositum (xvI) . . . (in Fōrmulā Iv).

Suprā (xxxıv) . . . . . . (in superiōre locō).

Surgō, surgere, surrēxī, surrēctum (II) . . . . . . . . (rogā magistrum).

Suscipiō, suscipere, suscēpī, susceptum (xLII) . . . . . (facere volō, et mox incipiam).

Suspiciō, suspicere, suspexī, suspectum (xv). . . . . (spectō illa quae super sunt). Sūspiciō, sūspīciōnis, $f$. (xlviıI) . (contrārium est Fidēs). Sustineō, sustinēre, sustinuī, sustentum (xLIV) . . . . (teneō nē cadat). Suus, sua, suum (viri) . . . . (cf. Suī).

\section{$T$}

Taberna, tabernae, $f$. (xIII) . . (pict. xxIII). Taceō, tacēre, tacuī, tacitum $($ xulx) . . . . . . . (nihil dīcō).

Tālis, tāle (xxx) . . . . . (huius generis: cf. Quālis?).

Tam (xxxiv). . . . . . (ef. Quam?).

Tamen (xxi) . . . . . . (sed).

Tandem (xxxviıi) . . . . (postrēmō). 
Tangō, tangere, tetigī, tactum (II) . . . . . . . (in Fōrmulā II).

Tantopere (xLIX) . . . . (tantum).

Tantum (xxxix) . . . . (tantummodo: cf. Quantum?).

Tantummodo (xviII) . . . . (hoc tantummodo, i.e., Nihil nisì hoc).

Tantus, tanta, tantum (xLII) . . (tam magnus).

Tèla, tēlae, $f$. (xxıv) . . . . (pict. xxiv).

Tèlum, tēlī, $n$. (xxıv) . . . . (id quō pugnāmus et quod in

Tempestās, tempestātis, $f$. pugnā iacimus).

(xxxıv) . . . . . (sī aqua dē caelō cadit, tempestās est).

Tempus, temporis, n. (xviI) . . ("Quid temporis est?" "Prīma est hōra").

Tenebrae, tenebrārum, $f$.

(xxxıv) . . . . . . (propter tenebrās nōn vidēmus: flammam facimus, sīc tenebrās dēlēmus).

Teneō, tenēre, tenuī, tentum (x) . (in Fōrmulā IV).

Tepidus, tepida, tepidum ( $x x x)$. (si quid tepidum est, paulum calōris habet).

Tergum, tergī, n. (xLviII) . . . (sī mē ā tē vertō, tergum vidēs).

Terra, terrae, $f .(\mathrm{xxI})$. . . . (pict. xxI).

Terreō, terrēre, terruī, territum (xxıII) . . . . . (id quod terribile est, nōs terret).

Terribilis, terribile (x) . . . (quod timēmus).

Tertius, tertia, tertium (xxIII) . (cf. Trēs: cf. quoque Prīmus, et c.).

Texō, texere, texuī, textum (xxrv). . . . . . . (pict. xxrv).

Tībiae, tībiārum, $f$. (xxxıI) . . . (pict. xxxıI).

Tïbīcen, tībīcinis, $m$. (xxxıI) . . (pict. xxxII).

Timeō, timēre, timūi $(\mathbf{x})$. . . (rogā magistrum).

Timor, timōris, m. (x) . . . (sī mē timēre vidēs, meum timōrem vidēs). 
Tollō, tollere, sustulī, sublātum (xx) . . . . . . . (rogā magistrum).

Torqueō, torquēre, torsī, tortum (I) . . . . . . . (in Fōrmulā I).

Tot (xxx). . . . . . (ef. Quot?).

Tōtus, tōta, tōtum (x) . . . (omnēs partēs tōtum faciunt).

Trādō, trādere, trādidī, trāditum (xLVI) . . . . . . (alterī hominī dō).

Trahō, trahere, trāxī, tractum (xuII) . . . . . . . . (rem dūcō vel rapiō post mē).

Trāns (cum acc.) (IV) . . . . . (in Fōrmulā III).

Trānseō, transīre, trānsī̄, trānsitum (xxIII) . . . . . . . (in alteram partem e⿳亠丷).

Tremō, tremere, tremuī (xxi) . (rogā magistrum).

Trēs, tria (rx) . . . . . (numerus ... III).

Tribūnus, tribūnī, m. (xLVIII) . (dux Rōmānus quī prō multīs imperābat).

Tribuō, tribuere, tribuī, tribūtum (xvir) . . . . . . (dō).

Trīstis, trīste (xvII) . . . (quī dolet: miser).

Tū, tuī (v) . . . . . . (... (ego) feriō, (tū ferīs, et c.)

Tum (xxI) . . . . . . . . . (ēo tempore).

Tumulus, tumulī, m. (xxxıv) . . (parvus mōns).

Turpis, turpe (xLv) . . . . (contrārium est Pulcher vel Illūstris).

Turris, turris, $f$. (xlviII) . . . (pict. XlvI).

Tuus, tua, tuum (viII). . . . (cf. Tū).

\section{U}

Ubi (xvir) . . . . . . . (quaestiō in Pēnsō xx).

Ûllus, ūlla, ūllum (xLviıI) . . . (contrārium est Nūllus).

Ulterior, ulterius (xLviı) . . . (ultrā, ulterior, ultimus).

Ultimus, ultima, ultimum (xxI) . (contrārium est Prīmus).

Ultrā (cum acc.) (L) . . . . (magis quam: diūtius quam).

Ultrō (xLviı) . . . . . (quoque: magis quam necesse est: proptereā quod volō). 
Umbra, umbrae, $f$. (xxıv) . . . (rēs nōn vēra quam vidēmus, et vēra esse vidētur).

Ūncia, ūnciae, $f .(\mathbf{I x}) \ldots \ldots$ (rogā magistrum).

Unde $(\mathrm{xx}) \ldots \ldots$. . . (quaestiō in Pēnsō $\mathrm{xx}$ ).

Undecim (Ix) . . . . . . (numerus ... XI).

Undique (xLIV) . . . . . . (in omnibus locīs).

Unguentum, unguentī, $n$. (L) . . (aliquid pingue quod in faciē fēminae pōnunt, pulchritūdinis causā).

Ūniversus, ūniversa, ūniversum (xuiv)........ (tōtus).

Ūnus, ūna, ūnum (Ix) . . . . . (numerus ... I).

Urbānitās, urbānitātis, $f$. (L) . . (modus agendī quī decet et omnibus placet).

Urbs, urbis, $f$. (xIII) . . . . . (pict. XIII).

Usque $(\mathrm{xxI}) \ldots . . .$. (semper: vērō: in tōtō).

Ūsūrpō, ūsūrpāre, ūsūrpāvī,

ūsūrpātum (xxvi) . . . . . (aliquid teneō per quod aliquid faciō).

Ǔsus, ūsūs, m. (xLviI) . . . . . (cōnsuētūdō, modus, necesse). Uter, utra, utrum (viri) . . . . (quaestiō in Pēnsō vini).

Uterque, utraque, utrumque

(xurv) . . . . . . (duo, sī duo sunt omnia).

Ūtilis, ūtile (xLIv) . . . . . (per quod aliquid bonī nōbīs facimus).

Ūtor, ùtī, ūsus sum (xLviI) . . (aliquid bonī per aliquid mihi faciō).

Ūva, ūvae, $f .(\mathrm{xv}) \ldots \ldots$ (pict. xv).

Uxor, uxōris, $f$. (xiII) . . . . (māter tua est uxor patris tuī).

\section{V cōnsonāns}

Vacuus, vacua, vacuum (xxix) . (quod nihil continet).

Vagor, vagāīi, vagātus sum

(xxxiv) . . . . . . (in omnēs partēs eō).

Valdē (xuix) . . . . . . . (maximē: cf. Validus).

Valē (xviir) . . . . . (contrārium est Salvē). 
Valeō, valēre, valuī (xxıx) . . . (validus sum).

Validus, valida, validum (xxıri). (quĩ multum potest).

Vāllum, vāllī, $n$. (xLVı) . . . . (mūnītiō).

Vehementer (xLvi) . . . . (magnō cum furōre).

Velut (xLII) . . . . . . (eōdem modō ac).

Vēnātor, vēnātōris, $m$. (xI) . . (pict. XI).

Vēndō, vēndere, vēndidì, vēndi-

tum (xıII) . . . . . . (rem tibi dō, dās mihi nummōs:

sĩc rem tibi vēndō).

Veniō, venīre, vēnī, ventum (Iv). (in Fōrmulā III).

Ventus, ventī, m. (xLIX) . . . (id quod spīrāmus, per terrās sē movēns).

Vērāx, vērāx (xxxvi) . . . . (vērācēs sunt illī quī vērum dicunt).

Verbum, verbī, n. (xxxvi). . . (vocābulum).

Vereor, verērī, veritus sum

(xuII). . . . . . . (timeō).

Vērō (xxxıI) . . . . . . . (cf. Vērum).

Versor, versārī, versātus sum (xxxıx) . . . . . . . (in omnēs partēs eō).

Vertō, vertere, vertī, versum (xxxıI) . . . . . (rogā magistrum).

Vērus, vēra, vērum (xıII) . . . (quod dīcimus esse, sī est).

Vesper, vesperis vel vesperī, m. (xxxıv). . . . . . . (ultima pars diēī).

Vester, vestra, vestrum (viII) . . (ef. Vōs).

Vetō, vetāre, vetui, vetitum (xviI) . . . . . . . (dīcō "Nōlī hoc facere").

Vetus, vetus (gen. veteris) (vIII). (rogā magistrum).

Via, viae, $f$. (xI) . . . . . (pict. $\mathrm{xI}$ ).

Victōria, victōriae, $f$. (xLIII) . . (sī in pugnā melior sum quam alius, eum vineō: victōria est mihi).

Vìcus, vīeì, $m$. (xxiv) . . . . . (urbs minima).

Videō, vidēre, vīdī, vīsum (II) . . (in Fōrmulā II).

Vigilō, vigilāre, vigilāvī, vigilātum (xxII) . . . . . (contrārium est Dormiō). 
Vìgintī ( $\mathrm{Ix}) \ldots \ldots$ (numerus ... . . Xxx).

Vìlicus, vīlicī, $m$. (xviıI) . . . . (is cui fundus cūrae est).

Villa, villae, $f_{.}(\mathrm{xI})$. . . . (pict. XI).

Vincō, vincere, vīcī, victum (xLVI) . . . . . . (superō).

Vir, virī, $m .(\mathrm{xI}) \ldots$. . . (homō: pater est vir, sed nōn puer, nōn anus).

Vireō, virēre, viruī (xxII) . . . (viridis sum).

Virga, virgae, $f .(\mathrm{xxxvI})$. . . . (pict. $\mathrm{xxxvI)}$.

Virgō, virginis, $f .(\mathrm{xxIv}) \ldots$. . (puella maior).

Viridis, viride $(\mathrm{xv}) \ldots . .$. (color: rogā magistrum).

Virtūs, virtūtis, $f$. (xxIv) . . (is quĩ fortis est, vel bonus est, virtūtem habet).

Viss, vīs, $f .(\mathrm{xxI}) \ldots \ldots$. . (rogā magistrum).

Vìta, vìtae, $f .(\mathrm{xI}) \ldots$. . (contrārium est Mors).

Vitis, vitis, $f .(\mathrm{xv}) \ldots \ldots$ (pict. $\mathrm{xv}$ ).

Vìvō, vīvere, vĩxī, vīctum (xxiv). . . . . . (vitam agō).

Vix (xiII) . . . . . . (nōn multum).

Vocābulum, vocābulī, $n$. (xxv) . (in Fōrmulīs Neutrī Generis).

Vocō, vocāre, vocāvī, vocātum

$(\mathrm{xxx}) \ldots . . . .$. (appellō: dīcō "Hūc venī").

Volnerō, volnerāre, volnerā vī, volnerātum (xxiv) . . . . (tèlō male faciō).

Volnus, volneris, $n$. (xxv) . . . (in Fōrmulīs Neutrī Generis).

Volō, velle, volūi (xıII) . . . . (dēsīderō).

Volpis, volpis, $f .(\mathrm{xv})$. . . . (pict. $\mathrm{xv})$.

Voltus, voltūs, $m .(\mathrm{xxI}) \ldots$. (pict. $\mathrm{xxI})$.

Voluntās, voluntātis, $f .(\mathrm{xL})$. . (id quod aliquis facere volt).

Vōx, vōcis, $f$. (xıII) . . . . . (id quod audīs, sī dīcō).

Z

Zōna, zōnae, $f$. (xLII) . . . . (pict. xxIv). 
THIS BOOK IS DUE ON THE LAST DATE STAMPED BELOW

\section{AN INITIAL FINE OF 25 CENTS} WILL BE ASSESSED FOR. FAILURE TO RETURN THIS BOOK ON THE DATE DUE. THE PENALTY WILL INCREASE TO 50 CENTS ON THE FOURTH DAY AND TO \$1.00 ON THE SEVENTH DAY OVERDUE.

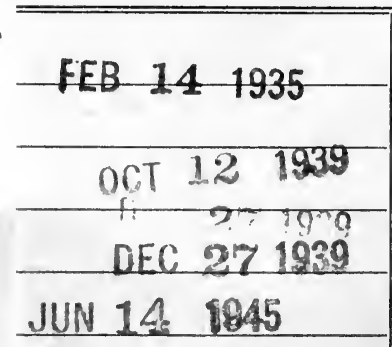




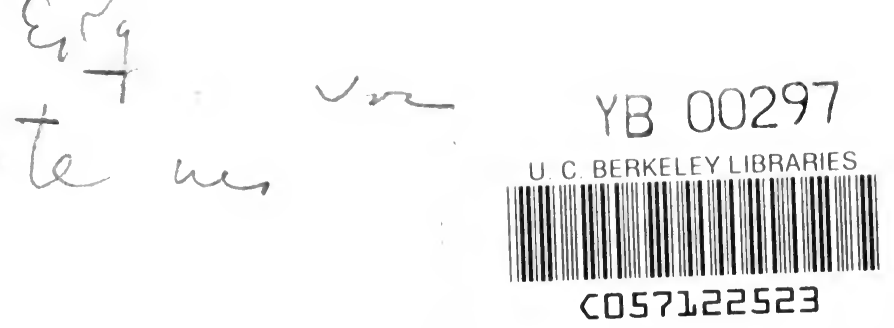


